FEB 221979

\title{
Mercury Deposits in Turkey
}

$\begin{array}{lllllllllllllllllllllllllllll}G & \text { E } & O & \text { L } & O & \text { G } & \text { I } & \text { C } & A & \text { L } & S & \text { U } & R & \text { V } & \text { E } & \text { Y } & \text { B } & \text { U } & \text { L } & \text { L } & \text { E } & \text { T } & \text { I } & \text { N } & 1 & 4 & 5 & 6\end{array}$

Prepared in cooperation with

Maden Tetkik ve Arama Enstitüsü

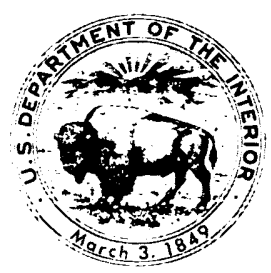

QE75

BSG

no. $145 t$ 


\section{Mercury Deposits in Turkey}

By MEHMET YILDIZ and EDGAR H. BAILEY

G E O L O G I C A L S U R V E Y B U L L E T I N 1456

Report prepared in cooperation with

Maden Tetkik ve Arama Enstitüsü

Mineralogy, geologic setting, size-grade of mercury ore bodies; brief history of productive mines

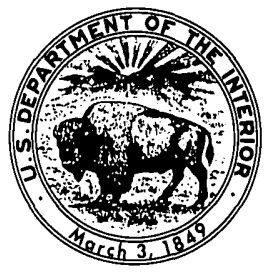




\section{UNITED STATES DEPARTMENT OF THE INTERIOR}

CECIL D. ANDRUS, Secretary

\section{GEOLOGICAL SURVEY}

H. William Menard, Director

Library of Congress catalog-card No. 78-600147

For sale by the Superintendent of Documents, U. S. Government Printing Office Washington, D. C. 20402

Stock Number 024-001-03134-5 


\section{CONTENTS}

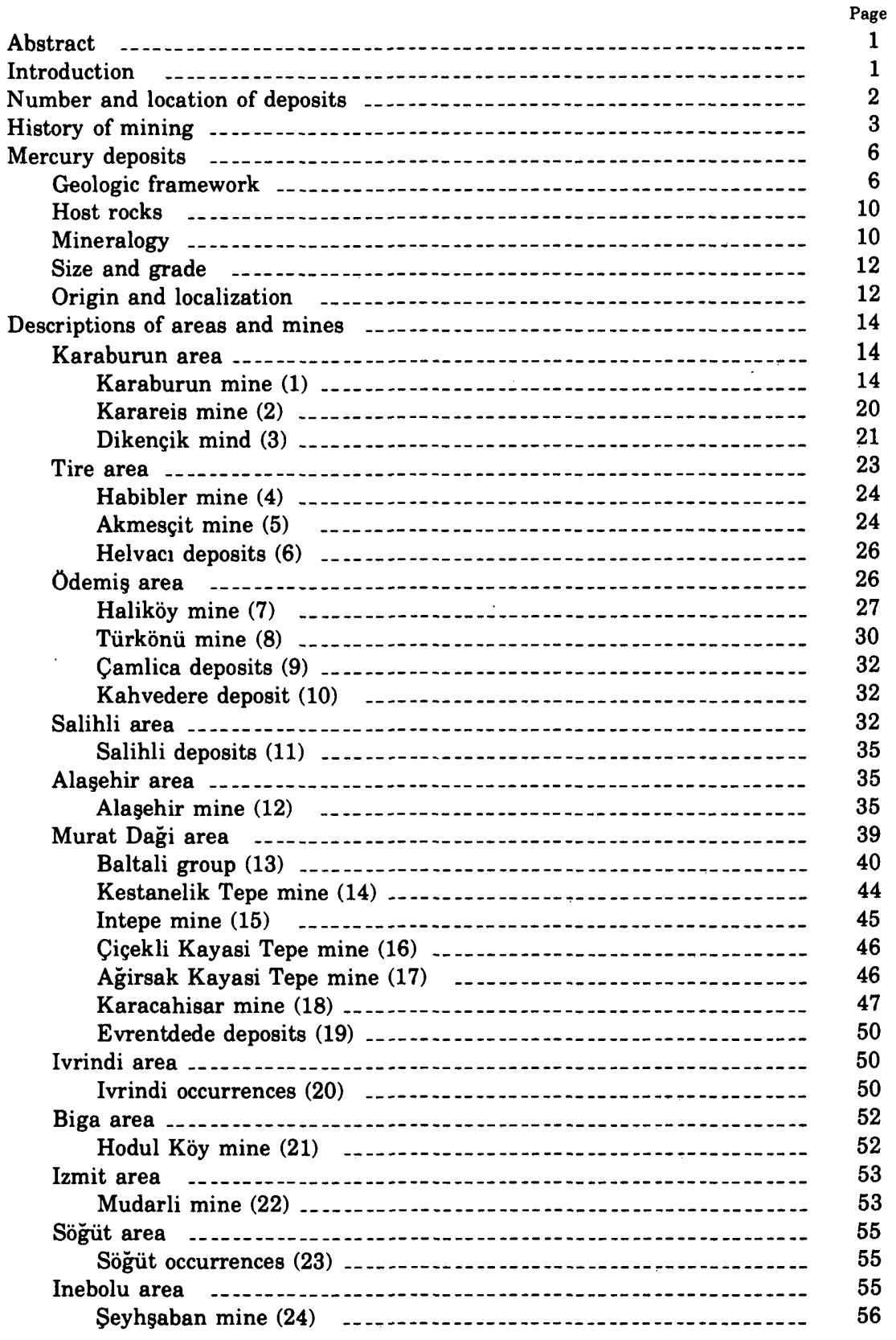


Descriptions of areas and mines-Continued Page

Konya area

Sizma mines (25)

Ladik mines (26) _.

Niğde area (_.

Gümüşler mine (27)

Mehmetleryurdu Sivrisi Tepe mine (28) _

Other deposits

References cited

\section{ILLUSTRATIONS}

Figure 1. Map of Turkey showing location of mercury deposits

2. Graph showing mercury production in Turkey, 1906-74

3. Map of Turkey showing the relation of the mercury areas to the main structural provinces

4. Map of the Karaburun Peninsula showing location of Karaburun, Karareis, and Dikençik mercury mines

5. Photograph of Karaburun mine viewed looking south -....-.-

6. Geologic map and cross section of the Karaburun (Kalecik) mine area

7. Photograph showing workers removing "burnt" ore from retorts at the Karaburun mine

8. Generalized east-west section through Karareis mercury deposit

9. Map of Tire area showing the location of the Habibler, Akmesçit, and Helvacı mercury mines

10. Geologic map showing Akmesçit mine and other mercury occurrences nearby

11. Map of the gneiss-schist contact from the Haliköy mine to the Kahvedere deposits

15. Geologic map of the Kahvedere mercury area

16. Geologic map of the area south of Alassehir showing the location of mercury and antimony deposits and outline of the Alaşehir mine area

18. Photograph of Alaşehir mine camp and retort area

19. Photograph showing bank of retorts in use at the Alaşehir mine in 1966

20. Map of the Murat Daği area northwest of Banaz showing areas covered by geologic maps of mercury occurrences (figs. 22, 24, and 27)

21. Photograph showing the 150-tpd rotary furnace plant installed near Banaz by Turkish Mercury Corp. in 1972

22. Map of part of the Murat Daği area showing the geologic setting of the Maden Sivrisi Tepe, Çakiraz Tepe, Satilmiş Tepe, and Kestanelik Tepe mercury mines 
Figure 23. Photograph showing opencut developed in gentle dipping opalite at the Baltali Maden Sivrisi Tepe mine

24. Geologic map of an area including the Intepe, Çiçekli Kayasi Tepe, and Ağirsak Kayasi Tepe mines

25. Photograph showing the spire of siliceous sinter(?) that contains the Çiçekli Kayasi Tepe ore deposit ....................

26. Photograph showing mined-out ore pipe in siliceous rock (sinter?) at Çiçekli Kayasi Tepe mine

27. Geologic map of the Karacahisar mine area

28. Geologic map of the area about the Evrentdede mercury deposits

29. Photograph of Evrentdede mine portal in weathered silicacarbonate rock

30. Photograph of one of six 4-pipe retorts being used in 1973 to treat ore from the Evrentdede mine

31. Geologic map and section of the Hodul Köy mine area

32. Geologic map of the Seyhşaban mine area .................

33. Photograph of Şeyhşaban mine viewed looking north .......-.

34. Photograph of elaborate system of mercury-condensing troughs on hillside above shaft furnace in use at Şeyhşaban mine .-

35. Map of an area northwest of Konya showing the geologic setting of the Sizma and Ladik mines -.........................

36. Photograph showing large opencut developed at the Büyük mine in the early 1970's

37. Structure contours drawn on the phyllite-limestone contact of the Büyük and Çaliça mines

38. Photograph showing shaft furnaces being used at the Büyük mine

39. Photograph showing modern furnace plant installed by Etibank south of Ladik to process ore from the Sizma and Ladik mines

40. Geologic map of the Çirakman mine area

41. Photograph of Çirakman mine area south of Ladik ........-

42. Photograph showing hearth of ancient mercury retort near Çirakman mine

43. Drawing of ancient mercury "retort" site and reconstruction, Çirakman mine area ...................................

44. Photograph showing iron shaft furnace and ground-level condensing system in use at the Çirakman mine ............

45. Map of the Niğde area showing location of mineral deposits --

46. Photograph showing ore sorting at Gümüşler mine into cinnabar-rich, stibnite-rich, and scheelite-rich piles

48. Photograph showing inclined-pipe Rossi-type retorts being used to recover mercury from hand-sorted ore at Gümüşler mine-

\section{TABLES}

TABLE 1. Production of mercury in Turkey by years, 1923-74 


\title{
MERCURY DEPOSITS IN TURKEY
}

\author{
By Mehmet Yildiz ${ }^{1}$ and Edgar H. Bailey
}

\begin{abstract}
Cinnabar was mined in Turkey for use as "paint" 8,000 years ago, and mercury metal was recovered in the Roman and possibly Greek eras. Modern production began early in the 20th century but remained small until the 1960's when rotary furnaces were installed. In 1974 Turkey produced more than 12,000 flasks of mercury, or about 5 percent of the world output.

The more than 50 known mercury deposits and occurrences are in the west half of Turkey, and most are in the central easterly trending belt constituting the Anatolid province. The major productive deposits cluster in five areas; three of these-near Konya, Karaburun, and Ödemiş-have yielded respectively $37,000,31,000$, and 26,000 flasks, about seven-eighths of the total recorded production.

The host rock for the ore is different for different deposits, and no variety seems clearly most favorable. Limestone is the host for the most productive ore bodies at Konya; silicified sandstone, tuff, and phyllitic shale contain the next most productive on the Karaburun Peninsula; and mica schist and gneiss are the hosts for the Odemis deposits. Everywhere cinnabar is the chief mercury mineral, but metacinnabar, native mercury, and swatzite occur in minor amounts. Pyrite is present in most deposits, marcasite in about half. Quartz is the common gangue mineral.

The ore and gangue minerals occur chiefly as fillings of fractures and are believed to have been deposited at shallow depth from warm ascending water. None of the deposits has been mined at depths greater than $150 \mathrm{~m}$; in most places, however, ore potential at greater depth was not tested. On the basis of typical erosion rates, we believe that none of the ore is older than Tertiary.
\end{abstract}

\section{INTRODUCTION}

Cinnabar is believed to have been mined in Turkey 8,000 years ago for use as "paint," and archaeological evidence indicates that mercury metal was recovered from the sulfide ore near Konya in Roman times or possibly even hundreds of years earlier by the Greeks (Barnes and others, 1972). Thus it may be that both cinnabar mining and mercury production first originated in Turkey. Despite these ancient beginnings, large-scale sustained mining of mercury was not done until recent years. Since 1969, however, production has been at a rate of more than 5,000 flasks per year and in 1974 reached a peak of more than 12,000 flasks, or about 5 percent of the world output. In 1974 several mines were equipped with modern rotary furnaces having a capacity exceeding 150 tons per day.

\footnotetext{
${ }^{1}$ Mercury commodity specialist, Maden Tetkik ve Arama Enstitüsü (MTA), Ankara, Turkey.
} 
Despite the advanced state of the industry, no comprehensive report on the mercury deposits is available in English; Yildiz (1967) and the Maden Tetkik ve Arama Enstitüsü (MTA) (1969) have provided short descriptions of most deposits in Turkish. Some brief summary reports are available (Ryan, 1957; Bekisoğlu, 1968; MTA, 1970), and for many deposits, unpublished reports are on file at MTA in Ankara. This report summarizes data on all known mines and occurrences, giving a brief description of their geologic setting, mineralogy, general character and size, and a historical sketch of their development, mining, production, and status in 1974. It has been prepared chiefly by Mehmet Yildiz, a mercury commodity specialist for Maden Tetkik ve Arama Enstitüsü, the Geological Survey of Turkey, assisted by E. H. Bailey, a mercury specialist for the U.S. Geological Survey. Yildiz has studied virtually all of the deposits over a period of years, whereas Bailey has studied in some detail the mines of the Konya area but has visited only briefly the other deposits.

\section{NUMBER AND LOCATION OF DEPOSITS}

The locations of all known mercury deposits and occurrences in Turkey, whether productive or not, are shown on figure 1 . Where several deposits are being mined in a single operation or deposits are so closely spaced that separation at map scale is impossible, an individual symbol represents more than one. Thus there are a few more deposits than indicated by the 50 symbols on the map, but the pattern correctly depicts all known areas of mercury deposits. Of the 50 deposits known, about half have some production and 17 have yielded more than 100 flasks $^{2}$ of mercury. The major productive deposits are in five clusters; three of which-those near Karaburun, Ödemiş, and Konya-have each yielded more than 25,000 flasks of mercury.

Geographically, the most striking aspect of mercury distribution in Turkey is its restriction to the west half of the country, as there are no occurrences known east of a line drawn from Sinop to Adana. Most of the occurrences and larger deposits are in the south half of Turkey; the single exception to this generality is the Şeyhşaban deposit near the Black Sea, with a production of 1,500 flasks.

\footnotetext{
${ }^{2}$ Mercury is customarily marketed in a steel cylinder or flask containing 76 pounds of the liquid metal; hence, the flask is the international unit of trade. There are approximately $34.5 \mathrm{~kg}$ to a flask and 28.5 flasks to a metric ton.
} 


\section{HISTORY OF MINING}

Mining of mercury deposits in Turkey in antiquity has already been mentioned and is described in more detail under the discussion of the Konya area where there is archaeological evidence of both pre-Bronze Age and Greek or Roman mining. From Roman times until about 1900 , some cinnabar ores doubtless were sporadically mined and retorted in Turkey, but owing to the lack of written records, all that remain to attest to this are slumped and caved workings, old dumps, and rumors.

By the beginning of the 20th century, the deposits at Haliköy and Habibler were known (Weiss, 1901), and by 1904 the ancient Sizma mine had been rediscovered (Sharpless, 1908). In 1902 a British company began mining at the Karaburun deposit, and by 1905 the Sizma mine was put into production. By means of shaft or tower furnaces, the Karaburun deposit is reported to have yielded more than 16,000 flasks of mercury before World War I, and the Sizma deposit has a production of at least half this amount. During this period, mining, hand sorting, and retorting in other areas also led to mercury recovery, but data regarding production from specific deposits are not available, as official records have been kept only since 1923.

During the interval from the beginning of World War I (1914) to the end of World War II (1946), despite three periods of relatively high mercury prices $(1914-19 ; 1926-31 ; 1939-45)$, only the Karaburun deposit had steady and significant production. In the early 1950 's, at the time of the Korean war and active stockpiling in the United States, the price of mercury began to rise, and after 1965 it skyrocketed to a record high level and was maintained at or near that level until 1970. In the mid-1950's the Karaburun, Karareis, and Sizma mines each produced a few hundred flasks through retort or shaft furnace operation, and prospecting by MTA and private companies was accelerated. In 1962 a modern rotary furnace was installed at the Haliköy mine, and in the following year it began a steadily increasing production that has continued into 1975. After the dramatic price increase in 1965, large furnaces were installed at the Karareis (1966), Türkonü (1968), Sizma (1969, 1970), and Seyhşaban (1971) deposits and at Banaz (1972) to process ores from the deposits of the Murat Daği area. At the Haliköy mine additional furnaces were added; at many small deposits activity increased and modest production was obtained from retorts. As a result of emphasis on mercury mining, Turkey's production rose from nothing in 


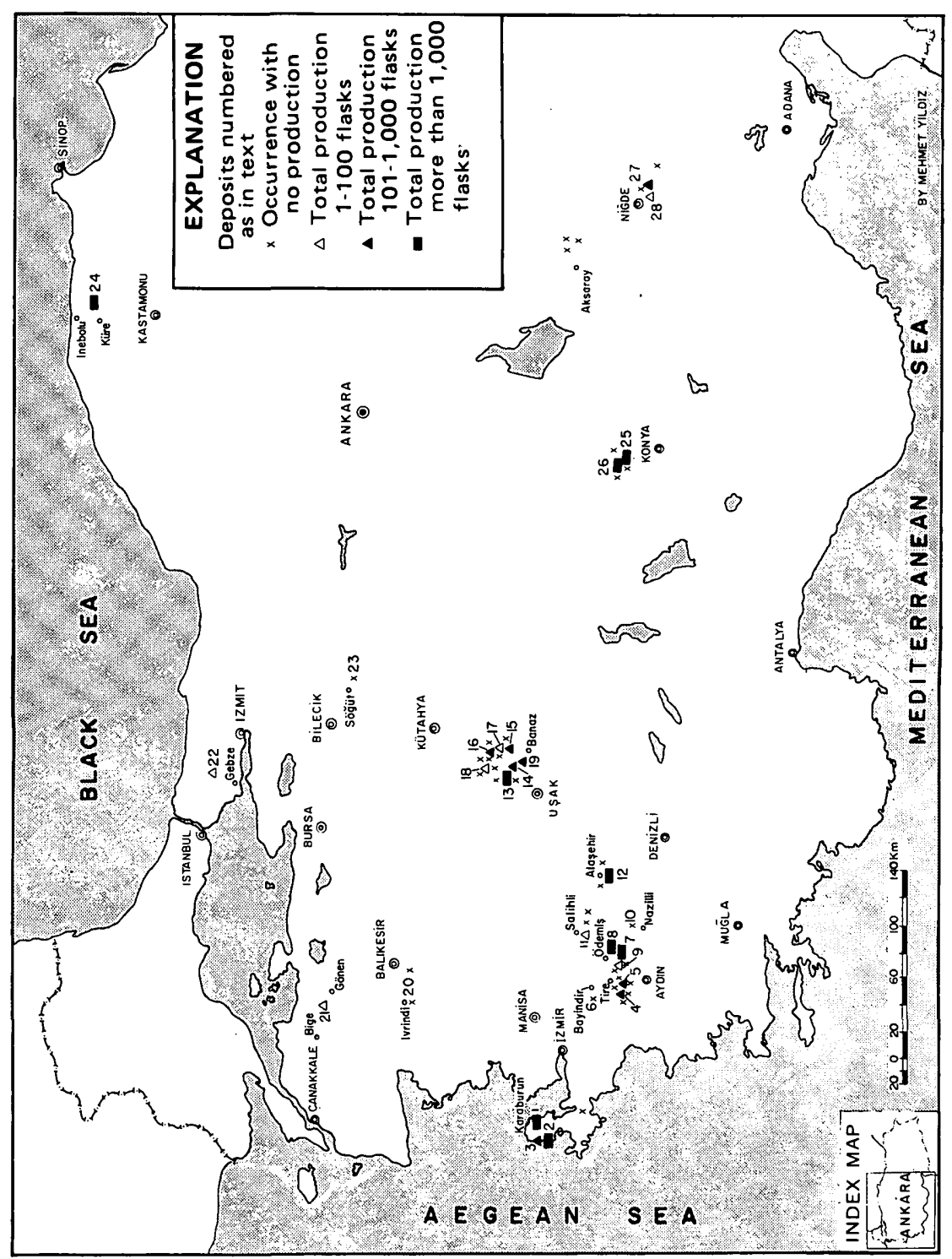




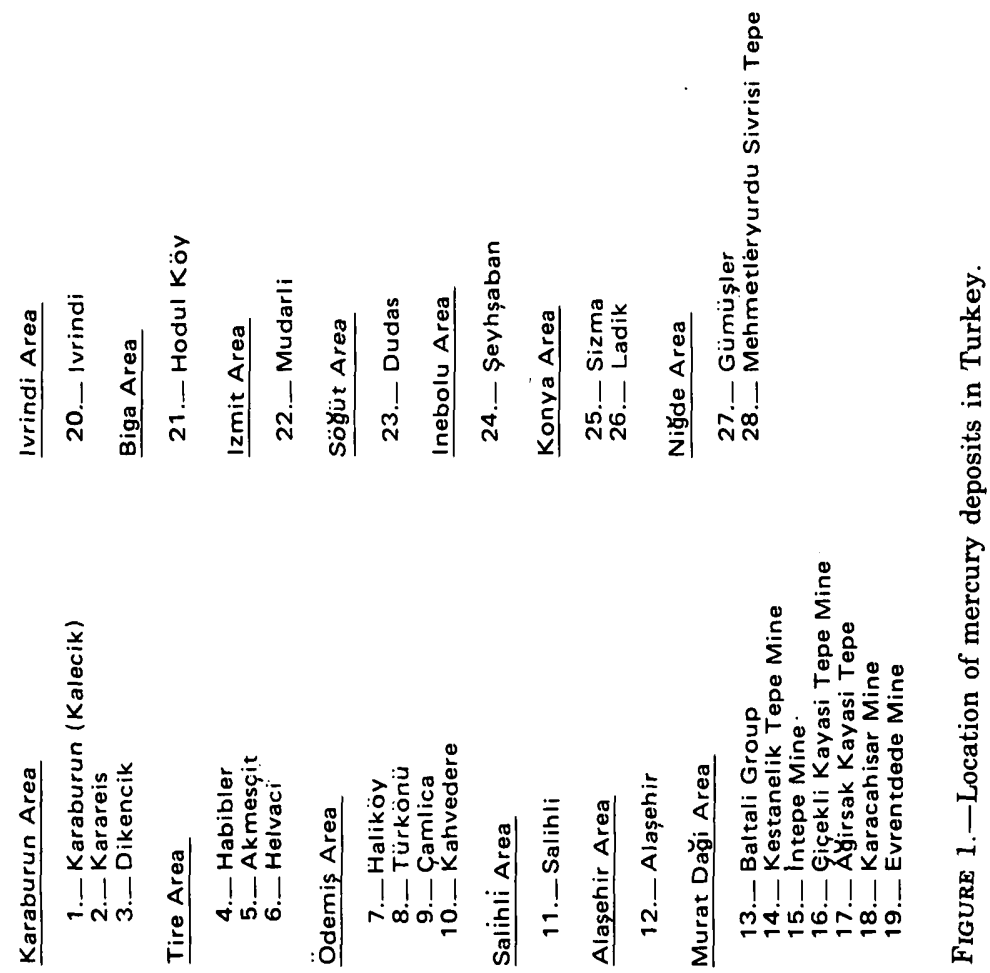


1953 to more than 1,000 flasks in 1956 , exceeded 2,000 flasks in 1960 , and increased almost steadily to a peak of 12,016 flasks in 1974 , the last year for which production records are available (fig. 2 and table 1).

TABLE 1.-Production of mercury in Turkey by years, 1923-74

[Data from published reports of Turkish Mining Department. _-, none reported]

\begin{tabular}{|c|c|c|c|c|c|c|}
\hline Year & & Flasks & Year & Flasks & Year & Flasks \\
\hline 1923 & -1 & 6 & 1941 & 354 & 1958 & 1,626 \\
\hline 1924 & & 226 & 1942 & 271 & 1959 . & 1,466 \\
\hline 1925 & $-\ldots$ & 100 & 1943 & 186 & 1960 & 2,143 \\
\hline 1926 & -..... & 161 & 1944 & 97 & 1961 & 1,863 \\
\hline 1927 & -.... & & 1945 & -158 & 1962 & 2,680 \\
\hline 1928 &..--- & 126 & 1946 & -- & 1963 & 3,049 \\
\hline 1929 & & 239 & $1947-$ & 98 & $1964-$ & 2,582 \\
\hline 1930 & ....... & 545 & 1948 & 27 & 1965 & 2,874 \\
\hline 1931 & & 239 & 1949 & & 1966 & 3,284 \\
\hline 1932 & -1 & - & 1950 & - & 1967 & 4,476 \\
\hline 1933 & .... & 23 & 1951 & - & 1968 & 4,791 \\
\hline 1934 & & 42 & 1952 & - & 1969 & 6,540 \\
\hline 1935 & $-\ldots$ & 25 & 1953 & - & 1970 & 9,402 \\
\hline 1936 & & 815 & 1954 & & 1971 & 10,351 \\
\hline 1937 & - & 483 & 1955 & 840 & 1972 & 7,636 \\
\hline 1938 & & 597 & 1956 & 1,079 & 1973 & $-8,900$ \\
\hline 1939 & & 395 & 1957 & -720 & 1974 & 12,016 \\
\hline 1940 & & 481 & & & Total & $-64,112$ \\
\hline
\end{tabular}

\section{MERCURY DEPOSITS}

\section{GEOLOGIC FRAMEWORK}

The mercury deposits in Turkey, like the deposits of Europe, Asia, and North America (Bailey, 1959; Bailey and others, 1973), occur in a large variety of rock types and diverse local structural settings. The Turkish deposits are, however, confined to certain major structural belts, as are the deposits on other continents, and even though this structural association is not well understood, the relations established empirically can be of value in deciding where to look for new deposits.

The complex geology of Turkey is summarized briefly here to indicate the relation of the mercury deposits to the main geologic provinces. Turkey is part of the vast Alpine-Himalayan mountain chain that was formed by early to middle Tertiary deformation and uplift of rocks that accumulated in the Tethyan trough in Mesozoic time. In terms of plate-tectonic concepts, this comparatively recent deformation that dominates the present geologic framework is the result of the convergence of the large rigid Eurasian and Afro-Arabian plates. The borders of these plates, however, contained Paleozoic 


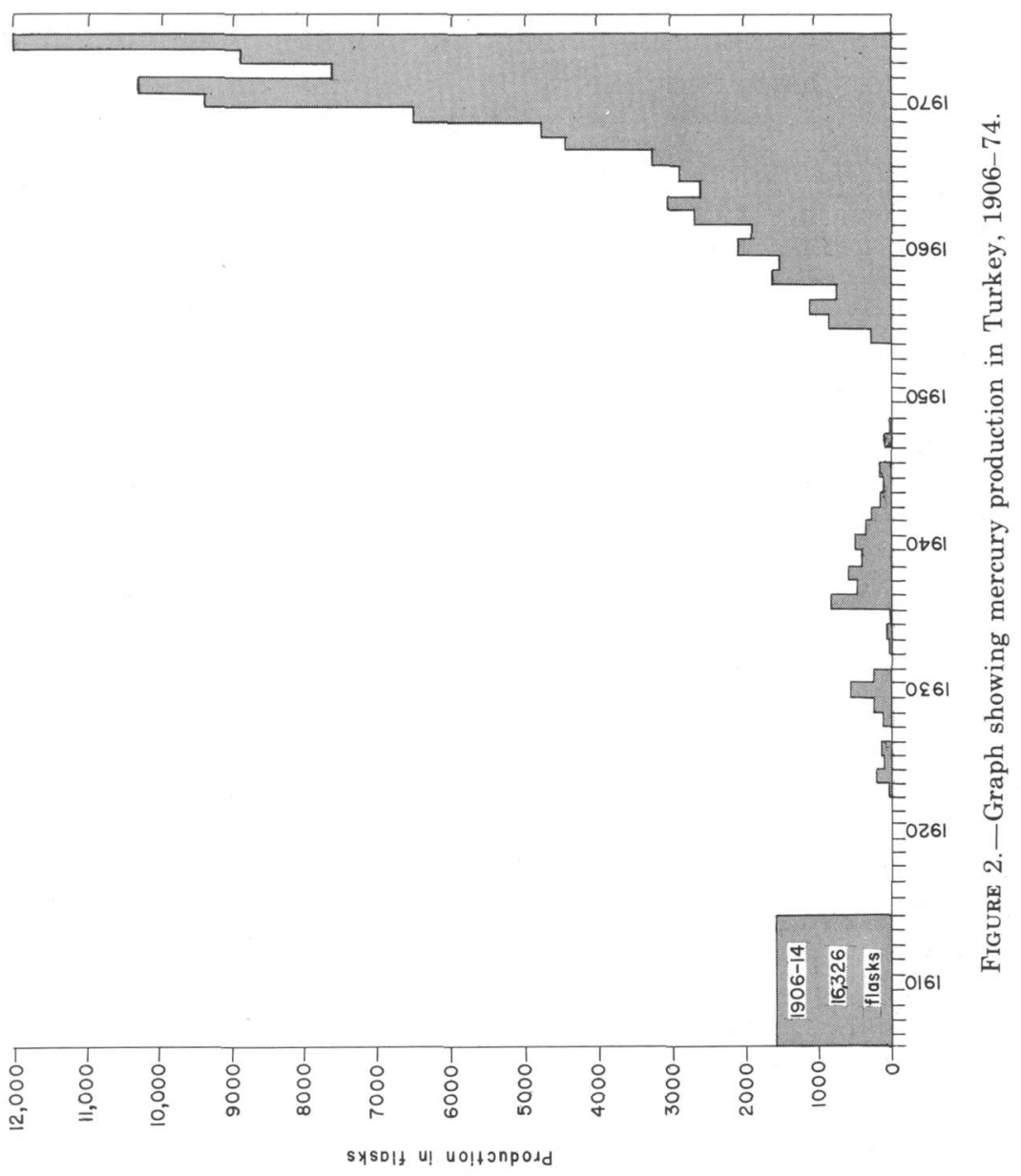


rocks previously deformed in the earlier Caledonian or Hercynian orogeny, and these rocks are exposed in Turkey. The framework formed as a result of these orogenies is as yet not wholly understood, especially where tectonic belts overlap, but there is general agreement that Turkey can be divided into four major regions having distinctive lithologic and tectonic characteristics.

The major geologic regions, as described by Ketin (1966), Evans (1971), Kamen-Kaye (1971), and other workers, are the Pontid, Anatolid, Taurid, and Border Fold regions shown in figure 3.

The Pontid region includes most of the older rocks in Turkey that have undergone deformation in the Caledonian, Hercynian, and early Alpine orogenies: Paleozoic sedimentary rocks, granitic masses, considerable mafic volcanic rock of Late Cretaceous and Eocene age, and sparse ultramafic rock. Since Oligocene time, the region has been a highland and the site of only minor volcanic activity. A few mercury deposits have been found in this region, but all are relatively small and unproductive.

The central Anatolid region is dominated by Upper CretaceousPaleocene eugeosynclinal lithologies and much ophiolite and blueschist (van der Kaaden, 1966, 1971), especially in its northwestern part. Some granite was emplaced in Late Cretaceous; soon thereafter, in the middle Alpine orogeny, this belt underwent its greatest deformation. Since that time the belt has been a continental landmass on which there have been numerous middle Tertiary and Holocene volcanic eruptions. All the major mercury mines lie within this region (fig. 3 ).

The Taurid region borders the southern Mediterranean coast and extends eastward to encompass the area about Lake Van. In this region Paleozoic sediments, largely metamorphosed to greenschistfacies rocks, are overlain by a thick Mesozoic marine sequence containing much limestone. Ultramafic rocks and other members of the ophliolite suite, believed to be Cretaceous in age, are abundant and widespread. Deformation began in early Alpine time and was very intense in the Oligocene; since that time the area has stood above sea level. Late Tertiary and younger volcanic rocks are predominant only in the eastern part near Lake Van. In spite of what would appear to be a favorable tectonic setting, no mercury mineralization occurs in the Taurid region.

That part of Turkey bordering Syria and Iraq lies in a geologic region referred to as the Border Fold belt. Since Cambrian time this area has been one of nearly continuous deposition of shallow-marine sedimentary rocks along the edge of the Arabian shield, and these strata remain neither intruded nor metamorphosed. During late Eocene to Miocene time, the rocks were strongly folded and locally 

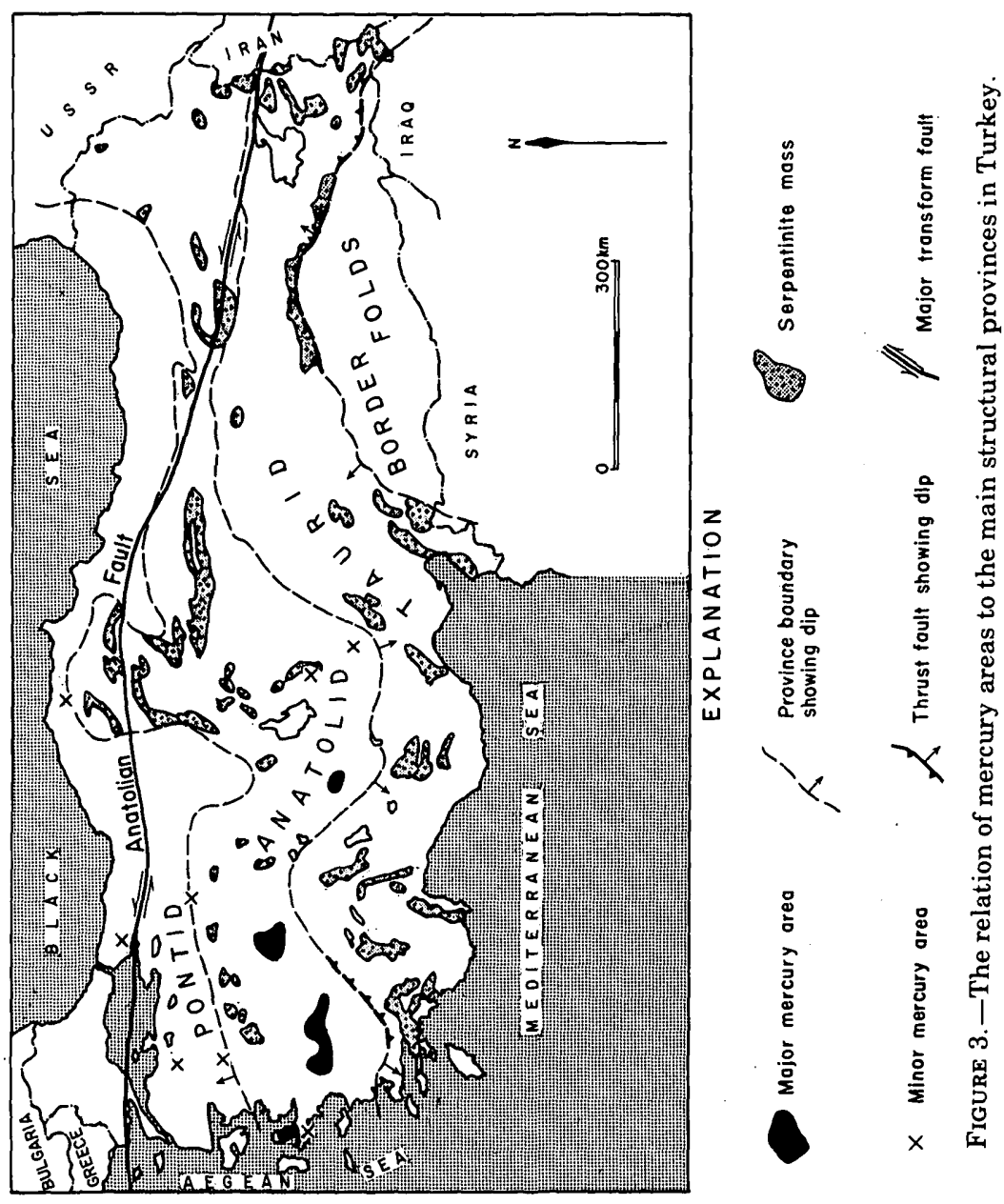
thrust-faulted by underthrusting of the Arabian shield beneath the rocks of the Taurid zone. The Border Fold rocks locally contain oil pools but do not contain mercury deposits.

\section{HOST ROCKS}

Although the mercury deposits are chiefly confined to the Anatolid region, they occur in many different kinds of sedimentary, igneous, and metamorphic rocks. Limestone is the host rock for the most productive ore bodies near Konya; silicified sandstone, tuff, and phyllitic shales contain the next most productive deposits on the Karaburun Peninsula; and mica schist and gneiss are the hosts for the Ödemiş deposits, which ultimately may prove to be the largest in Turkey. Other deposits occur in volcanic flows, tuffs silicified to form opalite, and silica-carbonate rock formed from serpentine (table 2).

\section{MINERALOGY}

The mineralogy of the mercury ores is generally simple, but in a few deposits antimony, arsenic, and tungsten minerals have been found (table 2). Cinnabar is the only economically important mercury mineral in all of the ore bodies, but minor amounts of metacinnabar, native mercury, and the mercurial variety of tetrahedrite named schwatzite have been identified. The cinnabar is generally fine grained, but at the Şeyhşaban and Sizma deposits it occurs locally in 1-mm crystals. Iron sulfides are nowhere abundant; pyrite has been seen in most deposits, and marcasite is reported to occur in about half of them. Stibnite is found in small amounts in a halfdozen deposits, and in the Niggde area is locally abundant enough to form ore in which cinnabar is a deleterious contaminant. Both at Niğde and at the Şeyhşaban mine, stibnite occurs in small crystals coated by later cinnabar. The arsenic sulfides, realgar and orpiment, though nowhere common, have been seen in a few deposits; but arsenopyrite, reported from two localities, has not been identified by us.

The common gangue mineral is quartz, found in every deposit, generally showing both pre- and post-cinnabar deposition. Carbonates are not so common, but calcite occurs in the three largest deposits, and dolomite has been identified in the Karaburun ores. Clay minerals of unknown species accompany the ores in several deposits. Purple, pale-blue, and white flourite occurs locally in the ores of both the Sizma and Ladik deposits in the Konya area, but its relation to the mercury minerals has not been established. A little barite has been seen in two of the mercury deposits. Scheelite occurs only in the Gümüşler deposit of the Niğde area, but here it is in coarsely crystalline clots in marble in sufficient abundance to have been mined and processed to form a tungsten ore concentrate (Wen- 


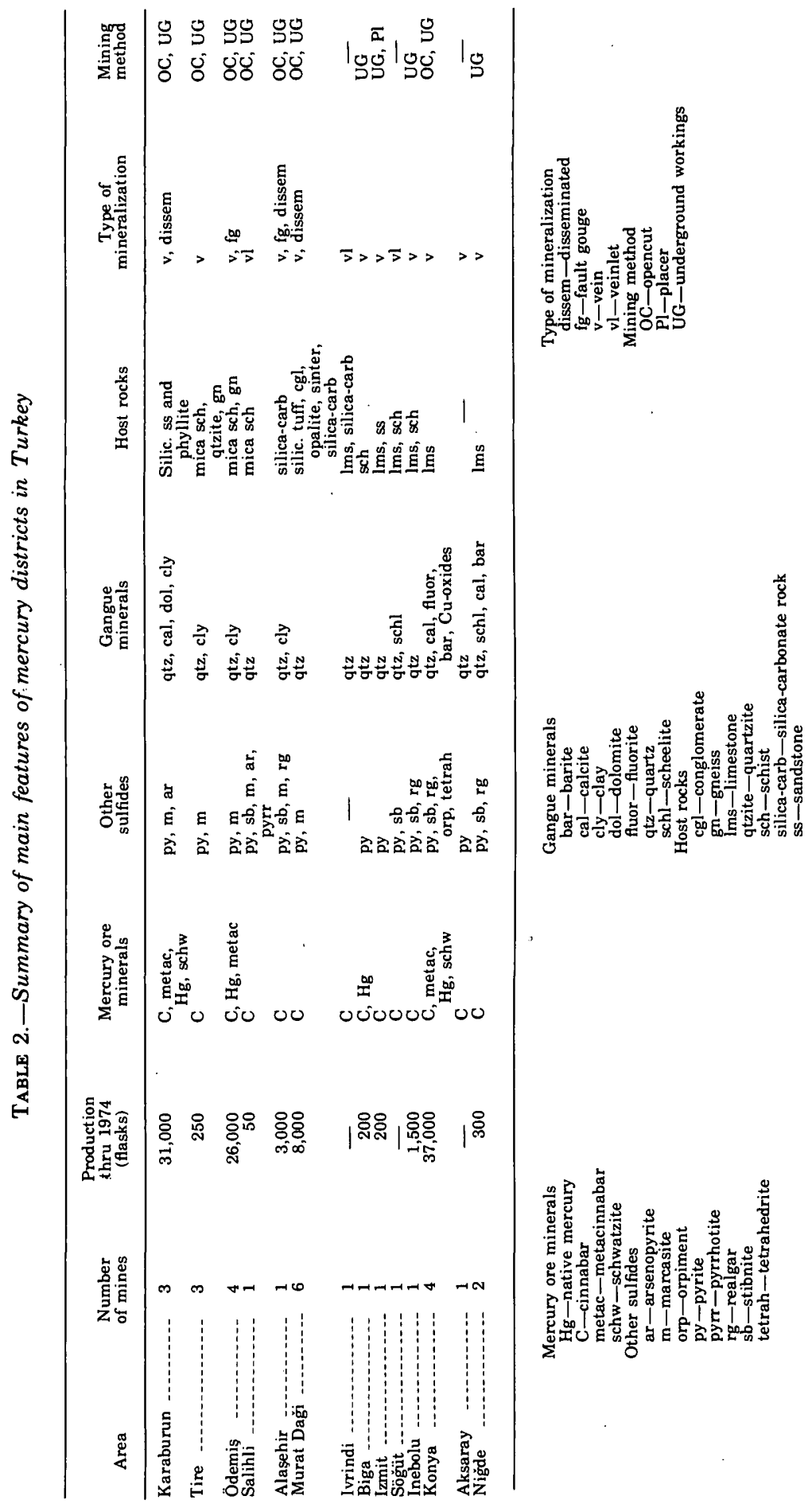


del, 1967). The scheelite was clearly deposited before the accompanying cinnabar and stibnite, and it is believed by Dennis (1970) to have formed in a different period of mineralization.

\section{SIZE AND GRADE}

As indicated by the records of production (table 1), none of the mercury ore bodies in Turkey is exceptionally large or rich. The grade mined is essentially a reflection of the prevailing prices, as lower grade ore is economic at times of high mercury prices. The largest ore body apparently was that of the Büyük mine in the Konya area, which, after initial mining of rich pockets, was ultimately mined out in an open pit measuring about $100 \mathrm{~m} \times 100 \mathrm{~m} \times$ $40 \mathrm{~m}$. The average grade of the ore is unknown but from the production record can be calculated to have been about 2.5 pounds to the ton, or less than 0.15 percent. Ore containing less than 0.1 percent was put through the large rotary furnaces in the early 1970's.

The ore body mined in the open cut at the Karaburun mine had dimensions of about $80 \mathrm{~m} \times 40 \mathrm{~m} \times 40 \mathrm{~m}$ and ranged in grade from 0.1-0.3 percent. Haliköy ore bodies are tabular along a fault zone, some extending more than $100 \mathrm{~m}$ in length, $60 \mathrm{~m}$ downdip, and having variable widths to $30 \mathrm{~m}$. The average grade of the ore being. mined in 1966 was 0.3 percent, and at times of very high mercury price it was even less, as lower grade material from the edges of the ore bodies was included. The Karareis ore is typically a little richer and at times averaged more than 1 percent without sorting, but the ore zone rarely exceeds $1 \mathrm{~m}$ in width. At the smaller deposits, where retorts rather than furnaces are utilized, ore is generally sorted to contain more than 1 percent mercury-the grade necessary for an economical small-scale operation.

\section{ORIGIN AND LOCALIZATION}

The cinnabar that has transformed barren rock into mercury ore bodies in Turkey in most places fills or coats the walls of fractures or other openings in the host rocks, generally accompanied by quartz. In the richer ores it also has replaced quartz, calcite, or other minerals along the walls of the openings. It is clear that the openings, though small in some places, provided the passageways for ascending waters that carried and deposited the cinnabar and the introduced gangue minerals. The waters were doubtless warm $\left(100^{\circ}\right.$ to $200^{\circ} \mathrm{C}$ ) and alkaline, and contained enough sodium sulfide to hold the mercury temporarily in solution as a sulfide, as calculations by Krauskopf (1951) have shown that dilute waters of this character are the only expectable natural waters that can transport and deposit significant amounts of mercury sulfide. Further, the experiments 
of Dickson and Tunell $(1958,1959)$ and Dickson (1964) demonstrate that such waters, saturated with mercury sulfide, would, on meeting ground water, precipitate cinnabar because of cooling or dilution. Tunell (1970) suggests that precipitation could also be caused by reaction with wallrocks, by solution of silica, or by oxidation. As they approach the surface, rising hot solutions normally will meet ground water and other environmental changes, and it is in the near-surface zone that cinnabar, or in some cases metacinnabar, would most likely be precipiated. The shallow character of mercury deposits throughout the world supports this origin, as few deposits extend to depths of more than $300 \mathrm{~m}$, and none is known to reach $1,000 \mathrm{~m}$.

The shallow depositional environment for mercury deposits has a further corollary when considered in terms of normal rates of erosion. Unless protected by a postore cover, a typical mercury deposit once formed would generally be removed by erosion in a relatively short span of geologic time. Typical continental erosion rates probably lie between $20 \mathrm{~m}$ and $50 \mathrm{~m}$ per million years (Gilluly and others, 1970); at this rate a mercury deposit that initially extended to 1,000 $m$ depth would be completely eroded in 20-50 m.y., less than the span of Tertiary time. Thus, most mercury deposits seen today are no older than Tertiary, and few are older than middle Tertiary. New deposits should be sought in areas where warm solutions were rising through the earth during this time, mainly those areas having major igneous or tectonic activity since the early Tertiary.

Other ideas regarding where to look for ore bodies can be gained from a consideration of geologic structure relative to the rising oreforming solutions. Clearly a passageway for the rising solutions is necessary, and this commonly will be a fractured zone along a fault. Where solutions rising in the fault zone reach the level of cool ground water, ore may be found in the fault zone, and major deposits in Turkey, like those of the Haliköy or Karaburun mines, may have formed this way. Not uncommonly a flexure in strike of an inclined fault forming an inverted trough will be enough to collect the solutions rising along the fault and bring about precipitation in the axis of the flexure. Where solutions rise through pervious or fractured rock and reach an area of trapping or stagnation, such as beneath a shale bed, ore may be formed because of the additional time available for reaction with the wallrock or ground water. An example of the effectiveness of this kind of trap is provided by the rich ore bodies in the limestone just beneath shale at the Büyük mine at Sizma, and here the solutions were further collected in those areas at the high axial parts of anticlinal warps in the contact. 


\section{DESCRIPTIONS OF AREAS AND MINES (MINES NUMBERED AS ON FIG. 1) .}

\section{KARABURUN AREA}

The Karaburun area is on the Karaburun Peninsula, which projects into the Aegean Sea near the center of the west coast of Turkey. It lies within the Karaburun township of the Izmir province about $60 \mathrm{~km}$ west of Izmir. Here steep mountains with prominent exposures of white Paleozoic limestone rise abruptly from the seashore to altitudes of more than $1,000 \mathrm{~m}$. The area contains three mines that together have yielded about 30,000 flasks of mercury, or roughly one-third of the country's total, and several other as yet unproductive deposits (fig. 4).

\section{KARABURUN MINE (1)}

The Karaburun mine, also called the Kalecik mine after a nearby village, is probably the second most productive mercury mine in Turkey. It is near the northern tip of the Karaburun Peninsula, about $4 \mathrm{~km}$ southwest of the seaside city of Karaburun. It is ac-

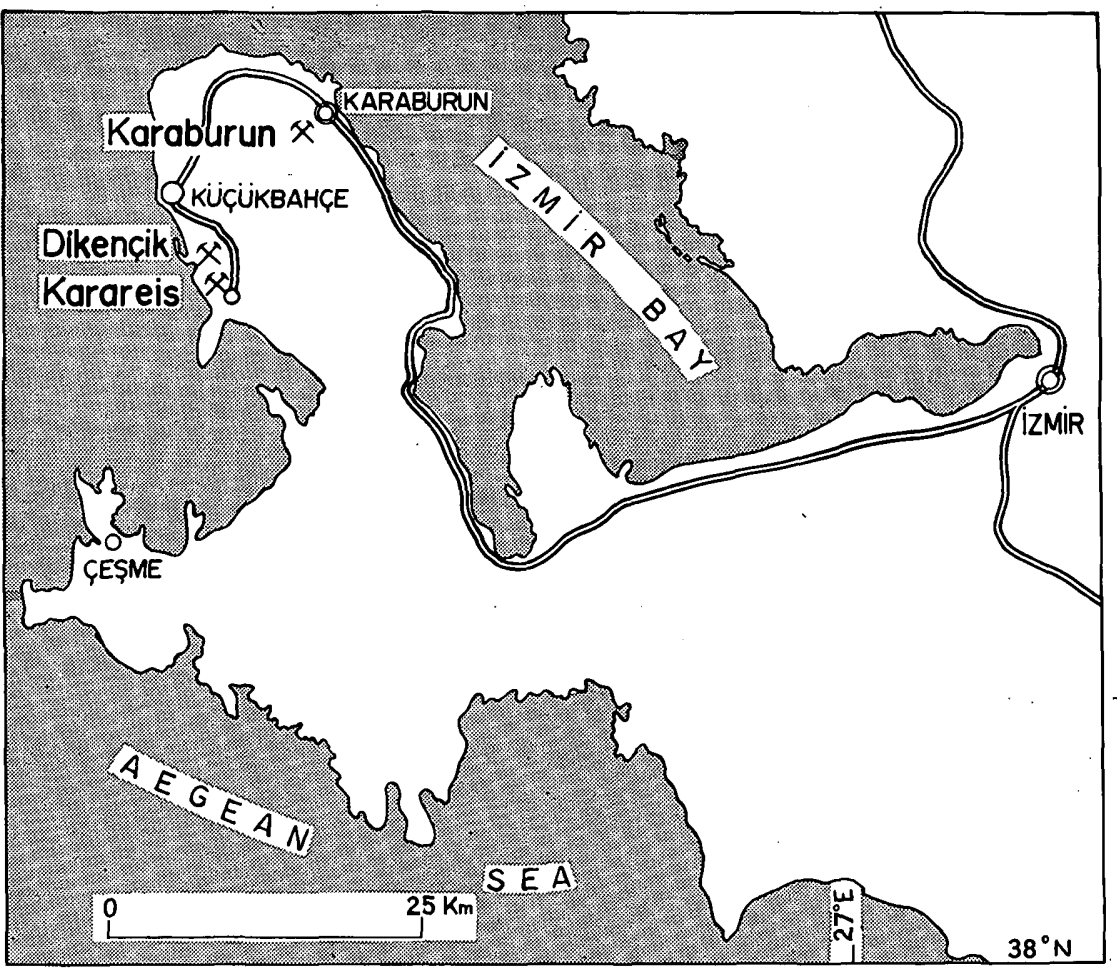

FigurE 4.-The Karaburun Peninsula showing location of Karaburun, Karareis, and Dikençik mercury mines. 
cessible from Izmir by $100 \mathrm{~km}$ of good road extending along the edge of Izmir Bay to Karaburun, followed by several kilometers of poorer steep roads that climb up the mountainside to the mine, nearly 450 $\mathrm{m}$ above sea level (fig. 5).

The geology of the Karaburun Peninsula has been studied by Kalafatcioglu (1961), and more detailed geology of the mine area as mapped by Yildiz is shown on figure 6. The oldest rocks, exposed just west of the mineralized area, are generally schistose clastic sedimentary rocks of probable Ordovician age and limestone of Devonian age more than $2,000 \mathrm{~m}$ thick (Ktenas, 1925). In fault contact with these rocks in the mine area is a sequence of steeply dipping beds of sandstone, conglomerate, tuff, and schist, to $200 \mathrm{~m}$ thick, constituting the Kalecik Formation of Triassic(?) age. Silicified parts of this formation contain the ore bodies. East of the mine, broken Jurassic limestone overlies the Triassic rocks.

About $3 \mathrm{~km}$ northwest of the mine is a stock of Paleozoic(?) granite intruding the older rocks, and a little Mesozoic(?) serpentine occurs along a fault west of the ore body. Several of the higher peaks are capped with basalt of Miocene(?) age, which prior to erosion probably blanketed much more of the area, and slightly older beds of tuff, clay, and marl occur near the city of Karaburun. As the ore is younger than the basalt, none of these igneous rocks seems to have a genetic relation to the mercury ore.

The rocks were deformed and faulted in the Alpine orogeny, which Kalafatcioğlu (1961) states began here in latest Cretaceous time and continued into Tertiary time. The absence of strong folding in the basalt suggests that since the middle Tertiary volcanism deformation has consisted chiefly of uplift. The most prominent fault in the area trends northwestward past the west edge of the ore deposit, separating the Paleozoic sedimentary rocks from those of Mesozoic age; it is offset in many places by faults striking to the northeast or east.

The chief ore mineral is cinnabar. Metacinnabar, schwatzite (mercurian tetrahedrite), and native mercury have been reported to occur (MTA, 1970) but were not found during our studies. Other sulfides are abundant fine-grained pyrite, some marcasite, and rare arsenopyrite. Abundant quartz, both as replacement of rock and as vein filling, is conspicuous in the ore, and a little calcite and dolomite are present.

Apparently only one main ore body has been mined. It was peanut shaped and has largely been removed through development of a northeasterly trending open pit $60 \mathrm{~m}$ wide, $120 \mathrm{~m}$ long, and $60 \mathrm{~m}$ deep. Wallrocks are strongly silicified dark-colored tuff, sandstone, pyrite-bearing phyllite, and local white quartzite breccia. In these 
silicified rocks, cinnabar occurred as veinlets, fracture fillings, scattered crystals, and masses. Where it is in veinlets, it may be accom-

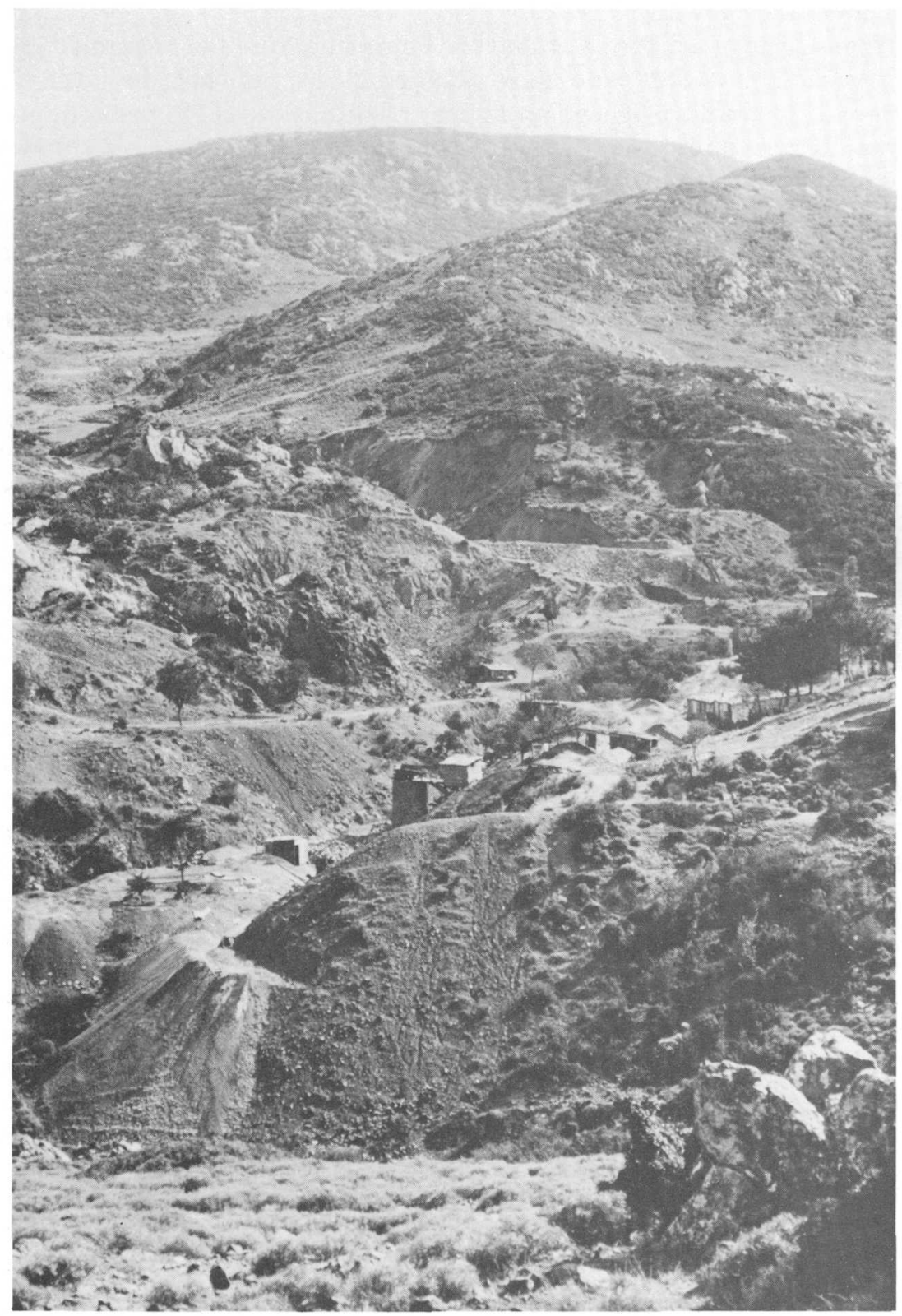

Figure 5.-Karaburun mine viewed looking south. Most ore was mined in open pit in center of picture above retort and camp buildings in foreground. 
panied by quartz; some is deposited in fractures in older, barren, and brecciated quartz-pyrite veins. Serpentine bordering the ore body remained little altered but locally contains a few veinlets of cinnabar, as does some nearby argillized basalt (Yildiz, 1969). The richest ore is reported to have been confined to zones striking westnorthwest and east-northeast. The average grade of the main ore body mined before World War I was reported to be 0.54 percent, and the actual metal recovered during the processing of more than 120,000 tons of ore indicates that this figure is essentially correct. Later mining produced about 29,000 tons with a recovered average grade of 0.45 percent.

The ore deposit is epithermal, containing chiefly mercury sulfide and quartz deposited from rising hot solutions. A channelway for the rising solutions was provided by the major northwest-trending fault passing near the west edge of the ore zone, but the major deposition was along the intersecting northeast-trending fractures. It seems likely that the ore was deposited just beneath the basalt flow that once extended above the ore zone but is now, as a result of erosion, found only as remnant patches on the hills about the deposit (see cross section, fig. 6). The localization of the ore below a blanket of basalt, probably as a result of trapping or rising solutions, doubtless explains why the ore at the surface was the richest, and why exploratory drilling has failed to find deeper ore bodies below the ore mined in the open pit.

The date of discovery of the Karaburun deposit is unknown, but modern mining was begun by a British company in 1902 (Ryan, 1957). By May 1906 the company had erected two Spirek shaft furnaces for processing coarse ore and one Czermak-Spirek furnace for finer ore and were producing 100 flasks a month, later increased to 250 flasks per month (Eng. and Mining Jour., 1908). During their 8 years of operation (1906-14), 122,000 tons of ore was treated (fig. 7), yielding 16,326 flasks of mercury.

During this early period the mine seems to have been developed nearly to its present state. In addition to the large pit, there is a haulage adit, $500 \mathrm{~m}$ long, about $25 \mathrm{~m}$ below the pit, and shorter workings have been driven for additional haulage or exploration, aggregating perhaps another $500 \mathrm{~m}$. A small amount of underground stoping is reported to have been done from one of these.

In 1927 the property was sold to a Polish company, which recovered only 407 flasks prior to selling to Turkish interests in 1936. From 1936 to 1948 mercury was recovered through retorting, but with constantly decreasing output as the supply of ore at the edge of the old pit became smaller in quantity and lower in grade. In this period, 1936-48, production is recorded as 3,726 flasks recovered 


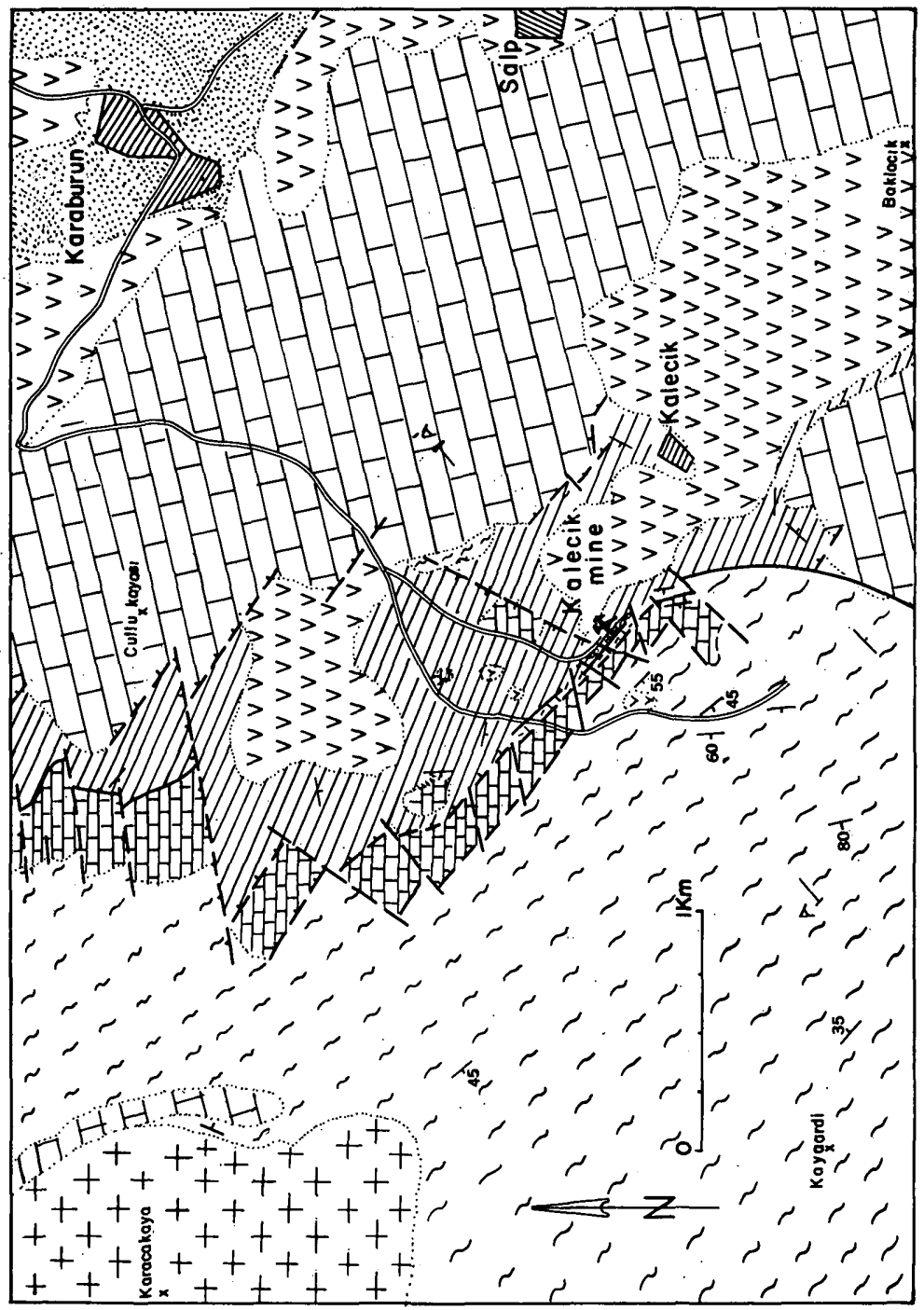



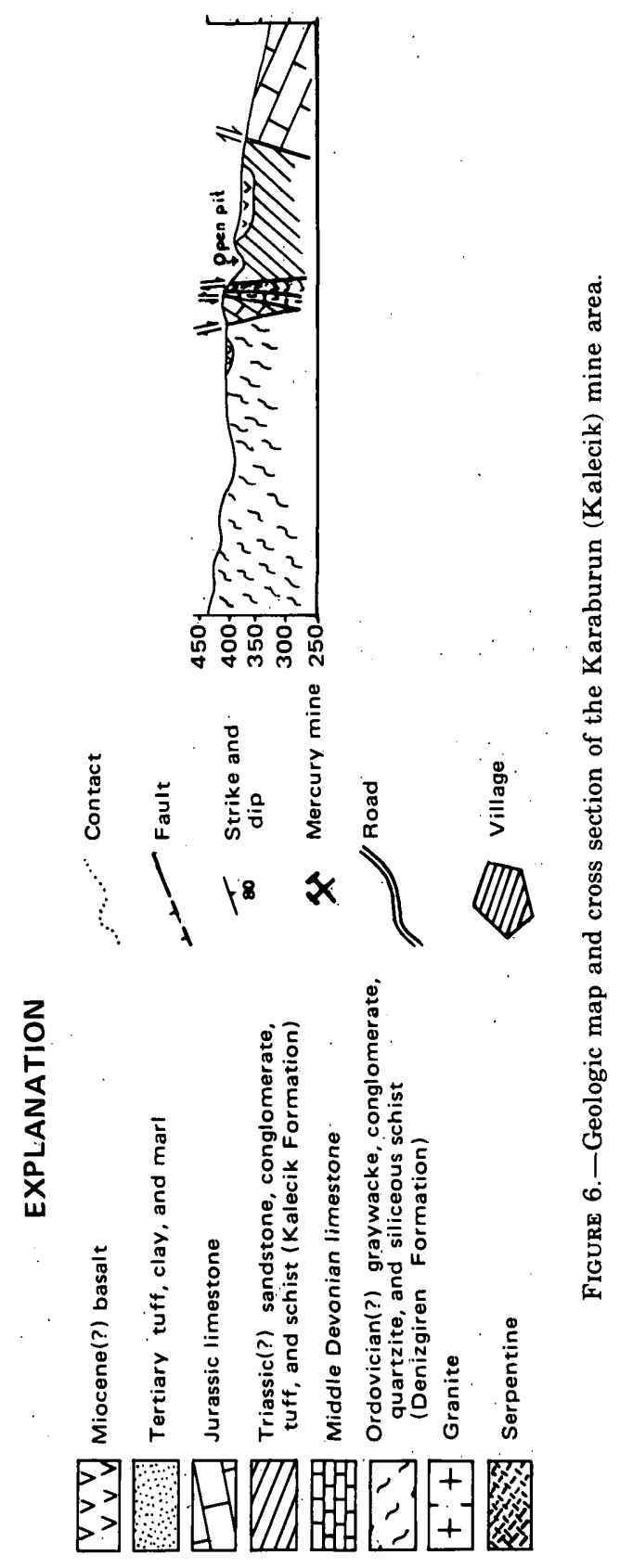
from 28, 931 tons of ore. When the price of mercury rose in 1955, the mine was worked again; it operated for a few years, treating ore initially in an old cascade-type furnace, and later in several twopipe, pan-charged horizontal retorts. From 1955 to 1963 production was only 729 flasks. When the mine was visited in 1966, two retorts were being operated (fig. 7) and production was said to be at a rate of about 30 flasks a month. After 1969 the Turkish Mining Corp. took the mine over, and exploratory drilling and other work was done by MTA. In 1973, after additional exploration, the Turkish Mining Corp. started working the mine again, hauling the best ore to a furnace near Banaz and stockpiling the leaner ore at the mine. Owing to the drop in price, this operation was short lived.

\section{KARAREIS MINE (2)}

The Karareis mine is very close to the Aegean shore on the west side of the Karaburun Peninsula, less than $20 \mathrm{~km}$ southwest of Karaburun in a straight line, but nearly $60 \mathrm{~km}$ by road (fig. 4). Its total production since modern mining began in 1955 is about 9,700 flasks of mercury.

The rocks of the area consist of two sedimentary formations. The older is the Denizgiren Formation, composed of alternating layers of Ordovician(?) micaceous or graphitic schist and sandstone that dip westward near the mine. It is unconformably overlain by a Middle Devonian sequence of conglomerate, massive limestone, and sili-

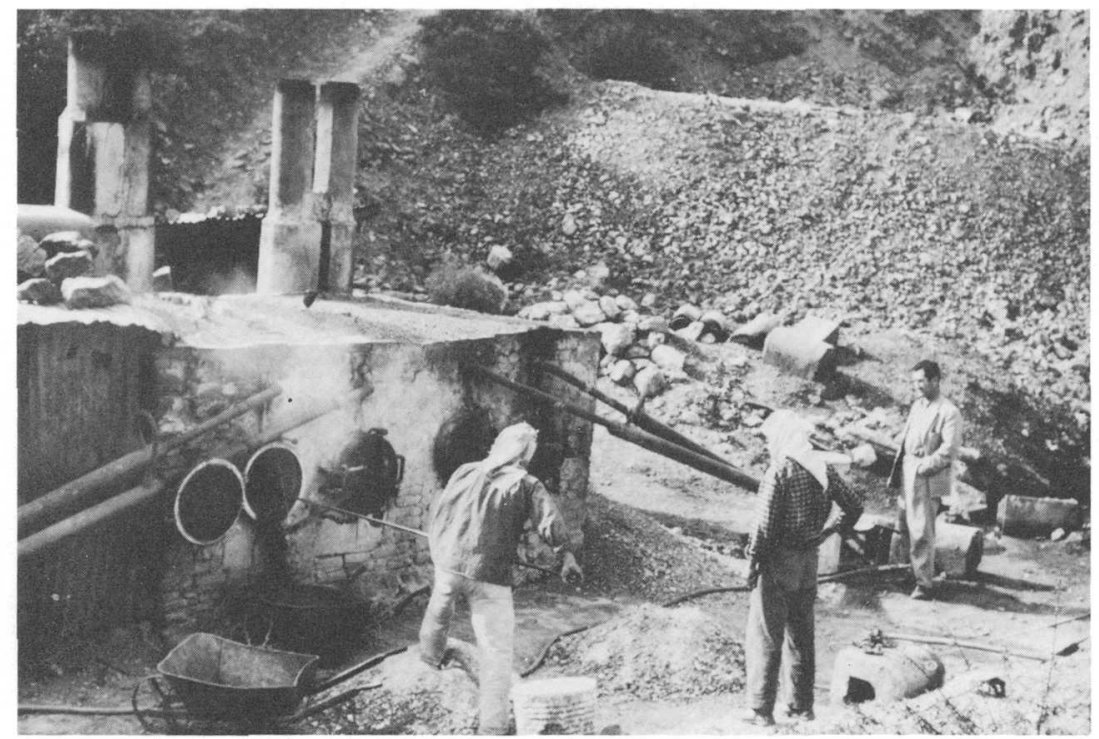

FiguRE 7.-Workers removing "burnt" ore from retorts at the Karaburun mine, 1966. 
ceous schist which dip to the east. The Denizgiren is cut by a northwest-trending fault that dips steeply to the east (fig. 8).

The dominant ore mineral is cinnabar, but some metacinnabar has been observed. Both pyrite and marcasite are present, and quartz is the common gangue mineral. The ore is mostly in a single rich quartz-cinnabar vein about $1 \mathrm{~m}$ wide in the fault zone shown in the cross section; some occurs in bordering silicified dark-gray phyllite. The grade of the ore as mined is generally above 1 percent and in some areas reaches 20 percent. The vein has been mined for a few hundred meters along the strike and about $65 \mathrm{~m}$ downdip. The lowest part was mined at a depth of about $60 \mathrm{~m}$ below sea level; because of the inflow of seawater, mining at greater depth was prohibited.

Although a little mining had been done at Karareis in an early but unknown period, modern mining and retorting began in 1955 under private operation. During the years $1955-57$, the mine produced a reported 664 flasks, then remained virtually inoperative until 1964, when an English firm in association with Turkish owners resumed production on a small scale. In 1966 a 25-tpd rotary furnace was put in operation, yielding 6-10 flasks per day from handsorted ore. During the following period of high mercury price, the richest part of the deposit was removed. A working force of 190 men was employed, and in 1967 a production of 1,159 flasks was recovered from ore averaging 0.8 percent mercury. In 1970 the furnace was enlarged to a capacity of $50 \mathrm{tpd}$ to offset a lowering of the price, but apparently mining was still not economic and production ceased. From late 1970 to 1972 some rich ore was hauled for processing to the Türkönü mine, near Ödemiş, but the amount of mercury recovered from it is not known.

The richness of the ore suggests that the search for other ore bodies along the same fault, or parallel faults nearby, might be rewarding.

\section{DIKENÇIK MINE (3)}

The Dikençik mine, about $6 \mathrm{~km}$ north of the Karareis deposit, has produced less than 300 flasks of mercury since its discovery in 1967. Cinnabar occurs here in quartz veins along a fault in silicified Paleozoic schist, forming an ore zone $0: 7 \mathrm{~m}$ wide and $75 \mathrm{~m}$ long. The ore is unique in Turkey in that it contains a considerable amount of native mercury, which makes it even richer than the otherwise similar ore of the nearby Karareis deposit.

The mine was operated with a bank of 10 inclined-pipe retorts, producing from hand-sorted ore about 250 flasks in the summers of 1967 and 1968. A private company purchased the mine in 1970, and during that year and 1971 some ore was hauled to the furnaces at 


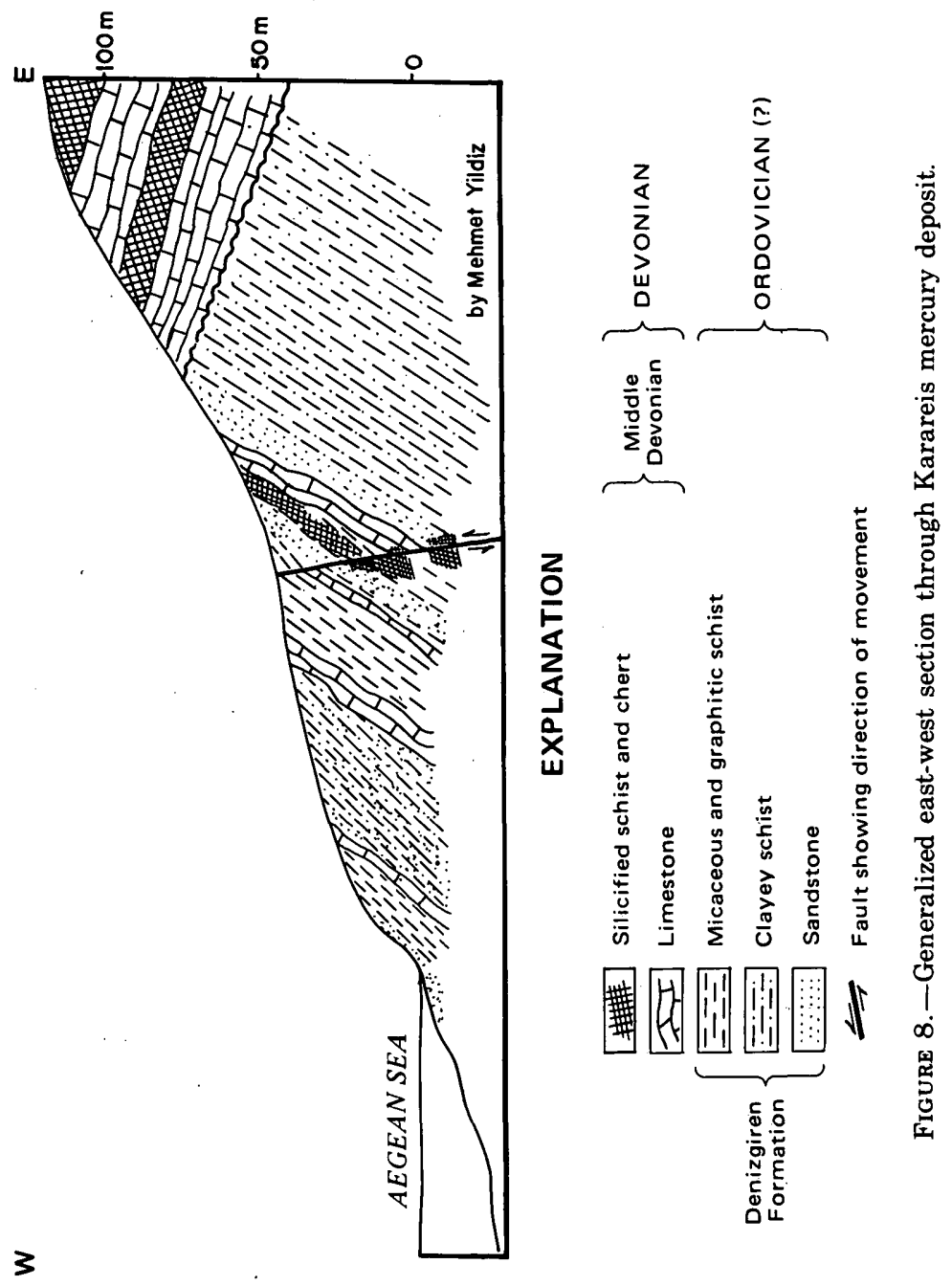


Karareis and Türkönü, but the amount of mercury recovered from it is not known.

A few other small deposits found near the mine do not appear to be economic, but the richness of the main Dikençik ore encourages further search for minable ore in the area.

\section{TIRE AREA}

The Tire area, in western Turkey near the southern border of Izmir province, about $70 \mathrm{~km}$ southeast of Izmir, contains two mines that have produced a few hundred flasks of mercury, and at least 10 unproductive deposits, as shown in figures 1 and 9 .

The Tire area is one of rough topography with valleys that are both steep and deep; it is largely covered with soil and vegetation which hinder prospecting. Bedrock consists of Paleozoic high-grade schist and gneiss that make up a part of the Menderes Massif. In these metamorphic rocks the mercury minerals occur in relatively

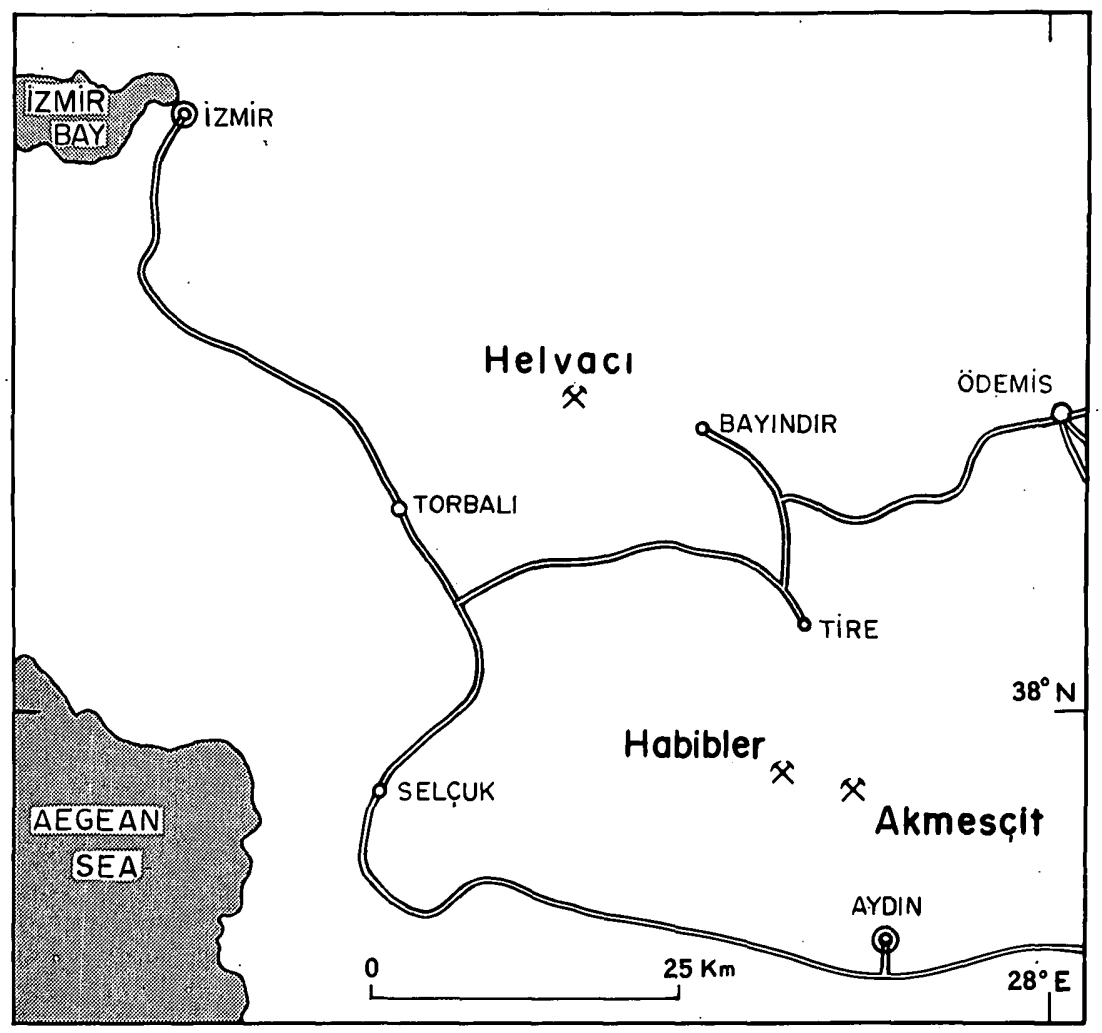

Figure 9. -Tire area showing the location of the Habibler, Akmesçit, and Helvacı mercury mines. 
small and low-grade concentrations along parting planes, fractures, and fault zones.

\section{HABIBLER MINE (4)}

The small Habibler deposits are near the village of the same name $17 \mathrm{~km}$ southwest of Tire. The area can be reached from Tire by a 25-km-long jeep road, or alternatively from the Aydin-Izmir highway by travel on a similar road for $20 \mathrm{~km}$. Several ore occurrences have been found on the margin of an upland plain extending east from the Habibler village, where bedrock of schist and gneiss is exposed along the upper edges of steeply incised valleys. The main deposit is on the south edge of the plain $1.5 \mathrm{~km}$ east of the village at an altitude of $700 \mathrm{~m}$; other deposits occur farther east and $2 \mathrm{~km}$ to the north.

Cinnabar, the only ore mineral identified, occurs with quartz and pyrite in veinlets following cracks in silicified parts of graphitic schist. The veinlets are concentrated in zones $15-20 \mathrm{~cm}$ wide and extending generally eastward for only a few meters, but farther along their strike, new mineralized zones may appear. The average grade of hand-sorted ore is about 0.5 percent, but some veinlets a few centimeters thick are virtually pure cinnabar. Antimony and tungsten have been identified in the ores by spectrograph (Höll, 1966), but minerals containing these elements have not been identified.

The mercury occurrences here have been known for at least 75 years (Weiss, 1901), but there is no record of early production. Beginning in the late 1960's, the mine was worked partly in a surface pit, partly by shallow trenches, and partly underground. Several hundred tons of sorted ore were hauled more than $300 \mathrm{~km}$ to Uşak, where they were retorted, yielding probably less than 100 flasks of mercury.

The main pit, a hundred meters of underground workings, and scattered trenches do not provide enough exposure to permit proper evaluation of the potential of the deposit, but it probably is small.

\section{AKMESÇIT MINE (5)}

The small Akmesçit mine is about 500 m west of the village of the same name and about $20 \mathrm{~km}$ southwest of Tire; to reach it from Tire, one must travel over $30 \mathrm{~km}$ of jeep road. The deposit is at an altitude of more than $1,000 \mathrm{~m}$ in an area of rough topography and sparse vegetation. As shown on figure 10, the rocks of the area consist of schist and gneiss striking generally east and dipping northward, mostly at angles between $20^{\circ}$ and $40^{\circ}$. Many faults and fractures, 


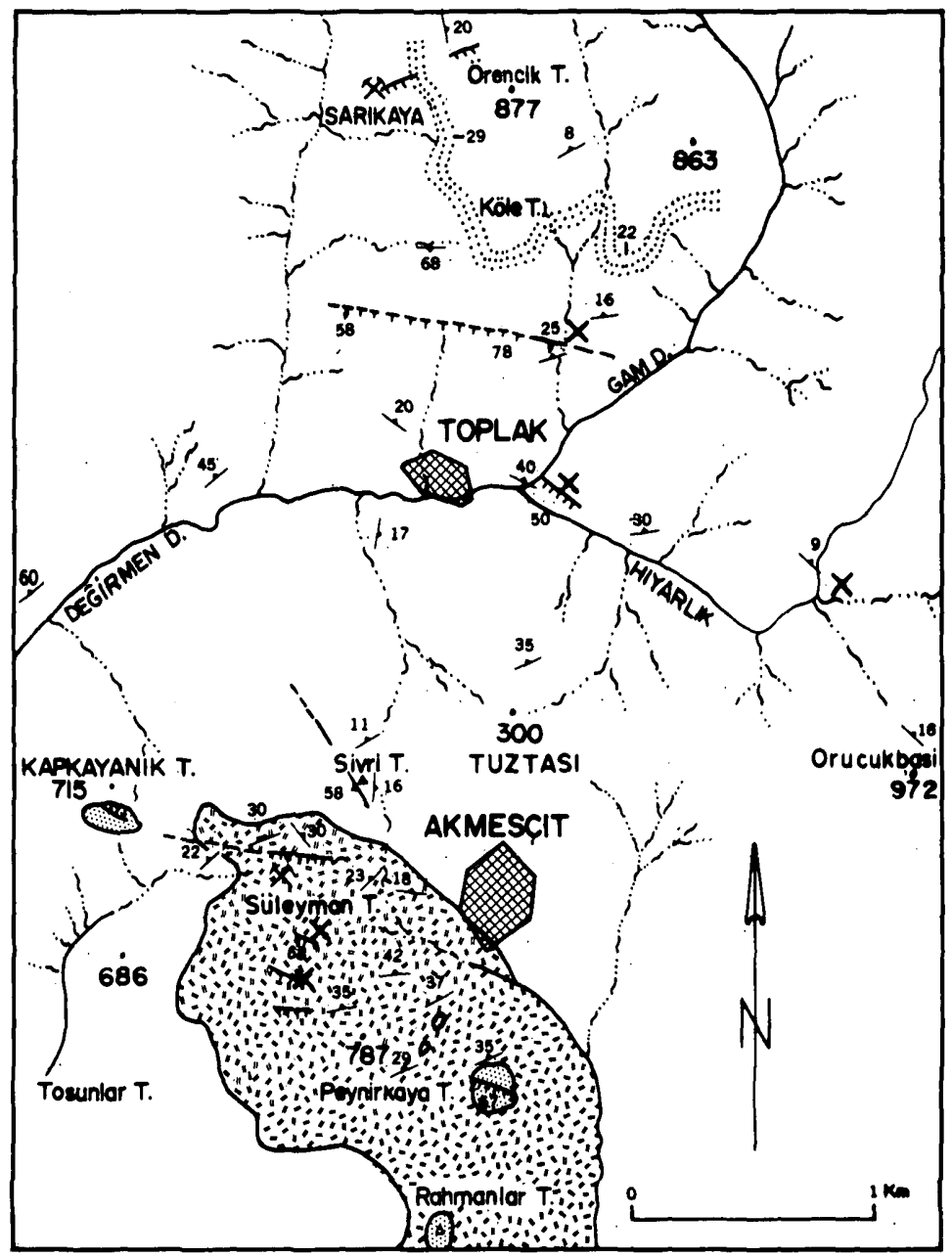

\section{EXPLANATION}

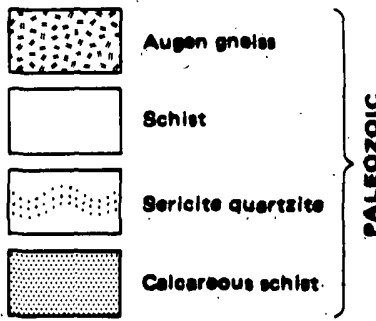

24 serlke end dip of follotion

Contect

7 . Fault, showine dip

$8 \dot{68}$ Altitude of point in metere

$x$ Mereury depoult with productien

$X$ Morcury depealt without preduction

FIGURE 10.-Geologic map showing Akmesçit mine and other mercury occurrences nearby. 
most of which trend eastward, cut the metamorphic rocks.

The only ore mineral is cinnabar, which occurs with quartz and some pyrite as veinlets to $2 \mathrm{~cm}$ thick in mylonitized zones along faults cutting the augen gneiss. The main production came from a discontinuously mineralized shear zone $20-40 \mathrm{~cm}$ wide extending for $150 \mathrm{~m}$ along a fault that strikes east and dips steeply to the south.

After its discovery in 1964, the deposit was worked until 1967 by a private company that mined in surface workings and by use of a bank of three two-pipe retorts recovered 145 flasks of mercury. However, because of the altitude of the mine and difficulty of access, mining was carried on only during the 6 summer months each year. The fault zone as exposed at the surface over a length of more than 1 $\mathrm{km}$ appears barren beyond the mined deposit, and the outlook for additional production is not encouraging.

Other occurrences of cinnabar in fractures along shear zones similar to that mined at Akmesçit are found at Toplak, $2 \mathrm{~km}$ to the north, and at Sarikaya, another $2 \mathrm{~km}$ farther north (fig. 10). These deposits appear unpromising, but at least two flasks were recovered at Toplak and seven at Sarikaya.

\section{HELVACI DEPOSITS (6)}

In 1972 cinnabar was discovered in a few places near the village of Helvacı, about $30 \mathrm{~km}$ northwest of Tire and $35 \mathrm{~km}$ southeast of Izmir. The village is accessible by $14 \mathrm{~km}$ of jeep road extending from the Aydin-Izmir highway at Torbali, which is about $50 \mathrm{~km}$ southeast of Izmir. The mineralized area is reached by traveling $3 \mathrm{~km}$ south of the village along the jeep access road and then walking northeast along $1 \mathrm{~km}$ of trail extending down a valley. The main deposit is at an altitude of $470 \mathrm{~m}$ in an area largely forested by pines and traversed by a perennial stream. The rocks consist of mica schist and graphitic schist that strike northwest and dip at gentle angles to the southwest.

Cinnabar occurs in small quartz veins with some pyrite for about $50 \mathrm{~m}$ along a shear zone in argillized sericitic quartzite. Some arsenopyrite also occurs along the zone, but its relation to the mercury mineralization is not clear. The mineralized zone strikes $\mathrm{N} .70^{\circ}-80^{\circ}$ W., dips $55^{\circ}-75^{\circ} \mathrm{NE}$., and is only about $10 \mathrm{~cm}$ thick. Parts of it, however, contain as much as 2 percent mercury. It has been explored by a few trenches made under a cooperative program of the United Nations and MTA. No mining has been done, and exploration is too limited to determine the potential of the deposit.

\section{ÖDEMIS AREA}

Most of the mercury deposits of the Ödemiş area are in the eastern part of Izmir province, but one deposit is just across the border in 
Aydin province. The area contains the Haliköy mine, in recent years the most productive mercury mine in Turkey, and several other productive deposits and prospects. All of the deposits are south or southeast of Ödemiş, which is reached from Izmir via $120 \mathrm{~km}$ of good road.

The bedrock everywhere is a part of the Menderes Massif and consists of mica schist and augen granite gneiss of Paleozoic age. As the topography is only moderately rugged, access is quite good, but the geology is somewhat obscured by vegetation, soil, and alluvial deposits.

\section{HALIKÖY MINE (7)}

The productive Haliköy mine is on the low north flank of the Aydin Mountains $4 \mathrm{~km}$ west of Beydağ, about $30 \mathrm{~km}$ by road southeast of Odemiş. It was initially operated on a major scale after 1962, when Etibank, the State mining organization, began to operate a large rotary furnace, and through 1975 it had produced 28,863 flasks of mercury.

The geologic setting of the Haliköy ore deposit is very simple. Granitic gneiss dipping moderately to steeply northward lies in a conformable relation on an underlying mica schist, which generally has a similar attitude. The contact between the two rocks, however, is a clayey gouge zone to $35 \mathrm{~m}$ wide that has been interpreted as a northward-dipping thrust fault. The contact from Haliköy eastward for about $6 \mathrm{~km}$ is nearly straight and resembles a recent fault (CENTO, 1964); farther east it becomes very irregular and transgresses the foliation of the rocks both above and below it, suggesting that it is an older fault that has been involved in tight folding (see fig. 11).

Cinnabar and minor metacinnabar, accompanied by quartz, pyrite, and marcasite, occur in the gouge zone along the gneiss-schist contact as veinlets and disseminations and in sheared mica schist in the lower part of the zone (see fig. 12). Some of the rather abundant clay is probably hydrothermal rather than tectonically ground rock, and as the ore is richest below the clay, its presence served to guide or trap the ore solutions rising along the fault zone. Three main ore bodies have been mined. The largest is about $100 \mathrm{~m}$ long, 5 to $30 \mathrm{~m}$ thick, and extends downdip at least $60 \mathrm{~m}$. Mining is done in several stopes reached by two main levels that are vertically $26 \mathrm{~m}$ apart. A third level $30 \mathrm{~m}$ deeper also is being used for ore extraction. The total length of the workings is about $3,000 \mathrm{~m}$.

The Haliköy deposit seems to have been first worked on a small scale sometime prior to World War I (Weiss, 1901). Its modern development, however, came as a result of work by MTA, which drove 


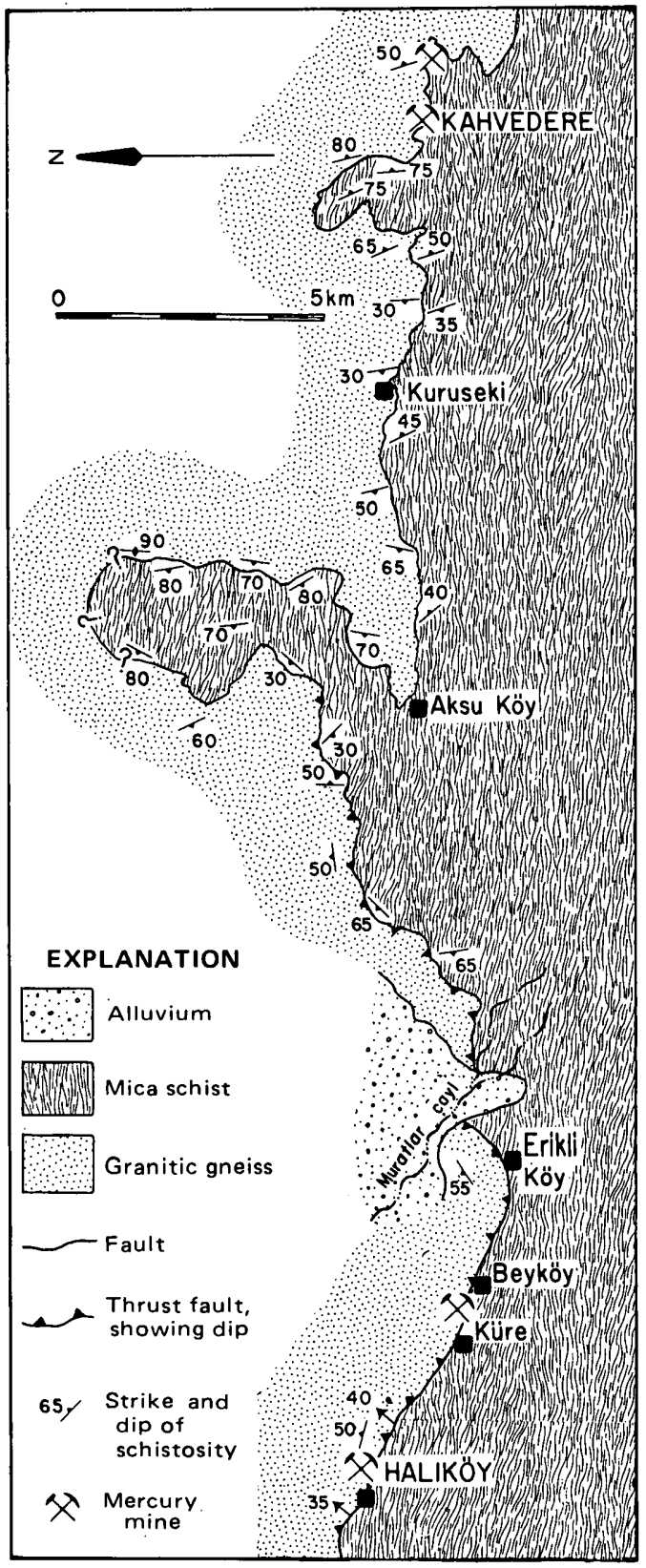

Figure 11.-The gneiss-schist contact from the Haliköy mine to the Kahvedere deposits. 
exploratory levels and raises in 1942, and in 1955 after additional drilling estimated a reserve of 240,000 tons of ore containing 0.4 percent mercury, equivalent to 25,000 flasks. Etibank obtained the mining concession in 1958, and by 1962 had a 25-m-long (100 tpd) oil-fired rotary furnace in steady operation. In 1966 a second rotary

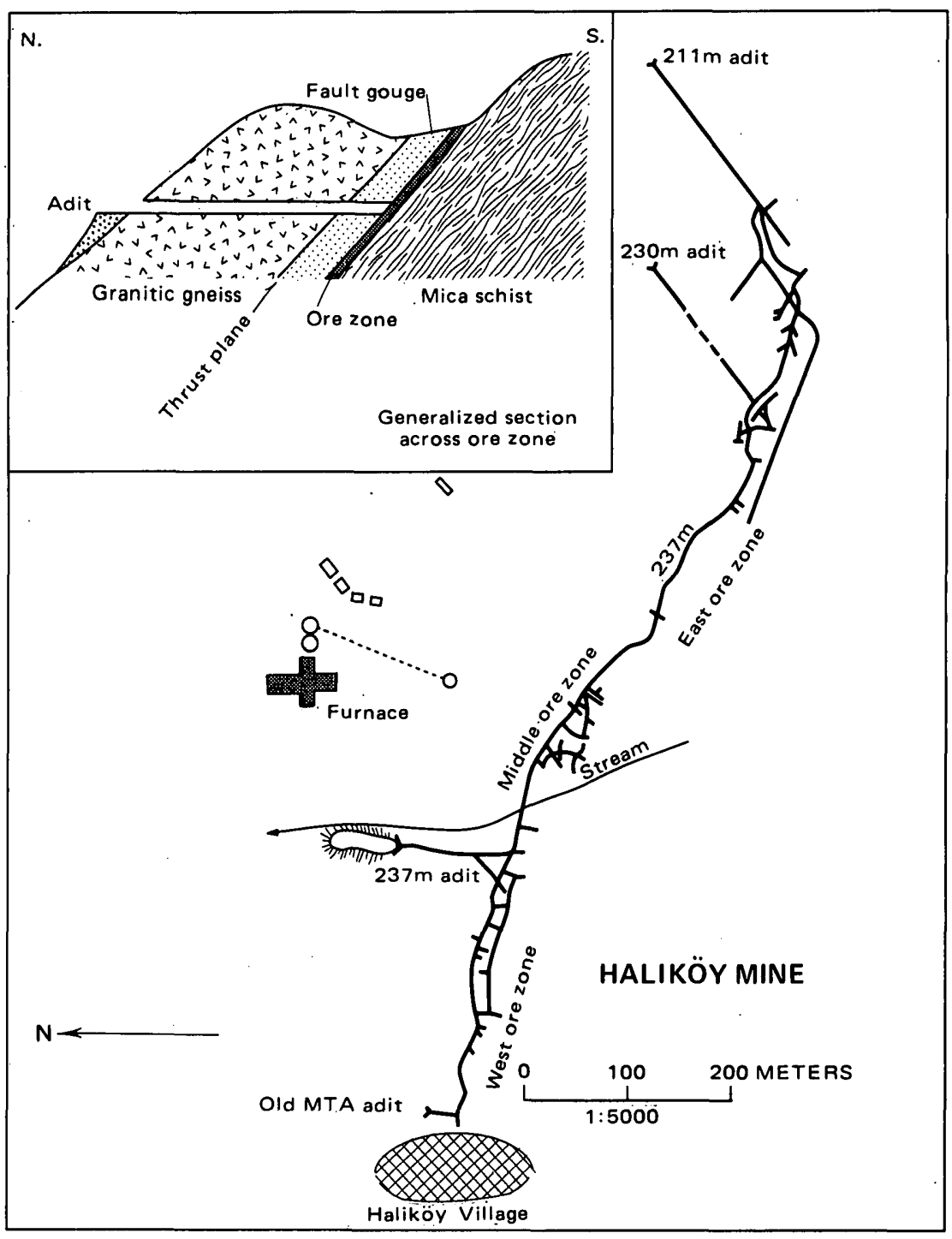

Figure 12.-Map and section of Haliköy mine, 1964, from CENTO (1964). 
furnace of the same size was installed, and in 1975 a 175-tpd furnace was moved here from the Sizma area (fig. 13). The grade of the ore processed depends on the prevailing price and cutoff in mining, but generally is between 0.15 and 0.3 percent. The production by Etibank is as follows:

$\begin{array}{rrrr}\text { Year } & \text { Flasks } & \text { Year } & \text { Flasks } \\ 1958 & \text { No production } & 1967 & 2,319 \\ 1959 & \text { Do. } & 1968 & 2,155 \\ 1960 & \text { Do. } & 1969 & 2,640 \\ 1961 & 19 & 1970 & 2,900 \\ 1962 & 20 & 1971 & 2,905 \\ 1963 & 763 & 1972 & 2,930 \\ 1964 & 1,008 & 1973 & 2,958 \\ 1965 & 1,254 & 1974 & 2,923 \\ 1966 & 1,944 & 1975 & 2,125 \\ & & \text { Total through } 1975 & 28,863\end{array}$

The outlook for the mine is very good, as the deposit has been mined only to a depth of less than $100 \mathrm{~m}$ below the outcrop; judged by its strike length and the strength of the ore-controlling fault, it should persist to considerably greater depth. Visible reserves in 1976 were reported to be more than 300,000 tons of ore, equivalent to more than 15,000 flasks, and probable ore was regarded to be several times this amount. In addition, undeveloped occurrences are exposed at the surface at other places along the outcrop belt of the fault.

\section{TÜRKÖNÜ MINE (8)}

The Türkönü mine, which has produced nearly 7,000 flasks of mercury in recent years, is $8 \mathrm{~km}$ southeast of Ödemis along the road leading to the Haliköy mine. The rock of the area is granitic augen gneiss, which is poorly exposed. Ore occurs where cinnabar accompanied by some pyrite is disseminated in a clayey zone along a fault that strikes east and dips to the north at a steep angle. The ore zone is about $500 \mathrm{~m}$ long, ranges in width from 1 to $5 \mathrm{~m}$, and has been mined downdip on several levels.

At some forgotten date, the deposit was mined on a small scale and produced a little unrecorded mercury. In 1965 a private company began to investigate the deposit and by 1968 had installed a 100 -tpd rotary furnace; in 1970, a furnace of similar size was added. However, the ore supply has been inadequate to keep both furnaces in continuous operation, and part of the time they have been used to process ore hauled from other deposits. Mercury production was terminated in 1975, owing to low price, and in 1976 the furnace plant was used to process antimony ore. 


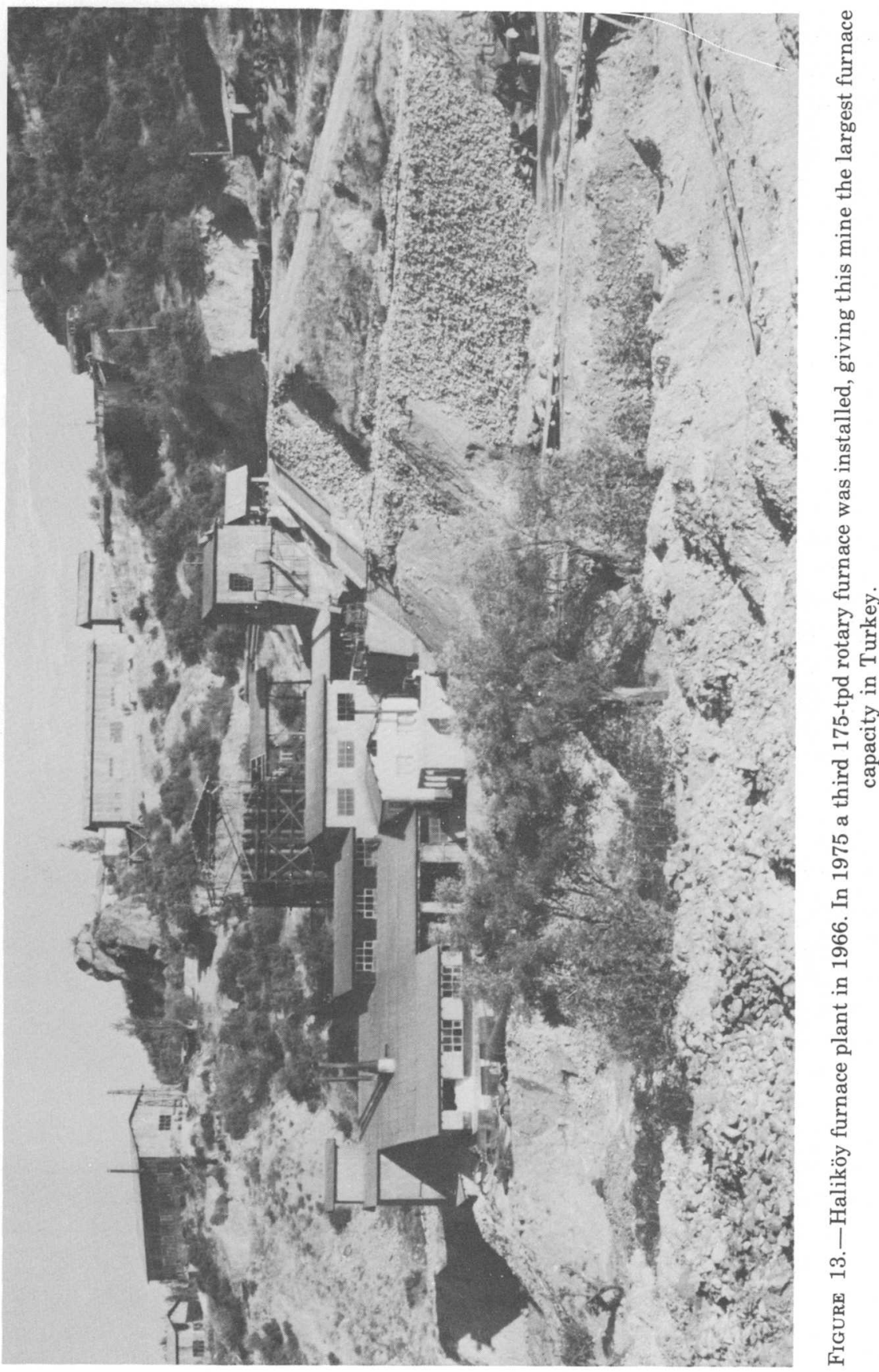




\section{ÇAMLICA DEPOSITS (9)}

Near the village of Çamlica, about $20 \mathrm{~km}$ south of Ödemiş and 12 $\mathrm{km}$ west of the Haliköy mine, are at least 10 small mercury deposits. Some of these have yielded a little metal through retorting, but in 1973 only one was worked. The aggregate production is probably no more than 100 flasks of mercury.

The rocks of the area include Paleozoic augen gneiss, graphitic and micaceous schist, gabbro, and minor quartzite of the Menderes Massif (fig. 14). Cinnabar, with some pyrite, occurs in small quartz veinlets and disseminations in the schist, especially along zones that have been bleached by hydrothermal solutions. Locally, where the veinlets are abundant, the ore is rich, but such areas of concentration are small and discontinuous. Despite the negligible known reserve, a profitable small-scale operation might be possible here if all the deposits were worked collectively and processed in a single retort.

\section{KAHVEDERE DEPOSIT (10)}

The Kahvedere deposit is in Nazilli township, Aydin province, about $15 \mathrm{~km}$ north of Nazilli and $25 \mathrm{~km}$ east of the Haliköy mine. The area is mountainous, and the deposits are at an altitude of nearly $1,000 \mathrm{~m}$. The occurrence was discovered in 1971 and has no production. The area has been studied by MTA by geologic and geophysical means, and the most promising occurrences have been further explored and sampled by surface trenching.

The deposit is on the eastward continuation of the gneiss-schist contact that contains the Haliköy ore deposit, but here the contact is much more irregular (see fig. 11). The mineralization is the same type as at Haliköy, with cinnabar, pyrite, marcasite, and quartz being concentrated along the contact (fault?) zone. Although clay alteration along the contact zone in the augen gneiss is intense and extends outward nearly $1,000 \mathrm{~m}$ from the contact along cross faults (see fig. 15), no ore bodies comparable in size and grade to those at Haliköy have yet been found.

\section{SALIHLI AREA}

The Salihli area, which contains several mercury deposits with very small production, is near the south edge of Manisa province, about $100 \mathrm{~km}$ east of Izmir, from which it is readily reached by a good highway. As the area borders the Salihli plain and is relatively flat, the road network within the area is good. Geologically the area lies in the northern part of the Menderes Massif; the rocks here consist of a lower unit of biotite quartzite alternating with quartzmuscovite schist, an upper unit of bitumin schist with marble lenses, and intrusive granite and granite gneiss. The mercury depos- 


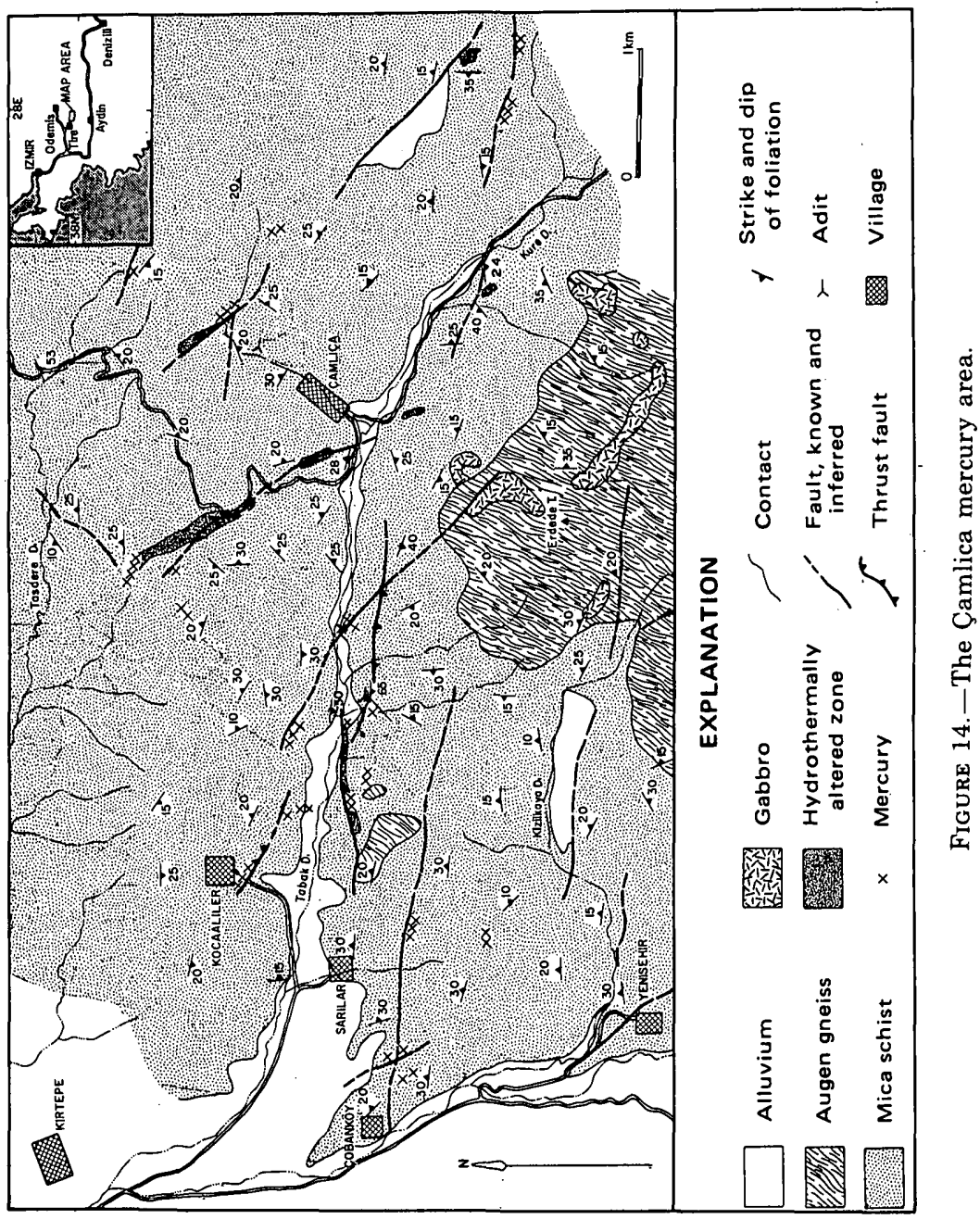




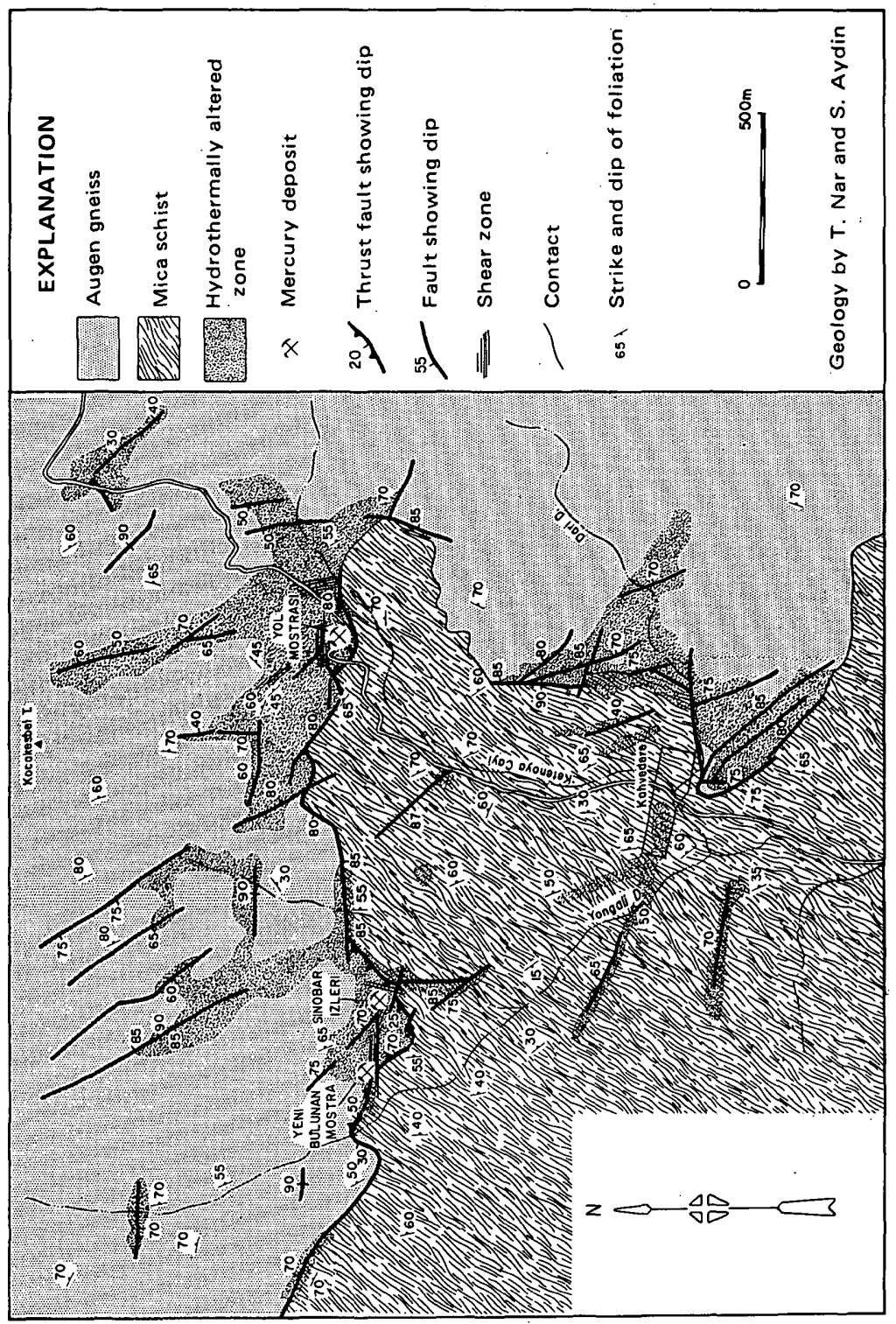

ฮั 
its occur in the metamorphic rocks along an easterly trending fault zone in the vicinity of hot springs.

\section{SALIHLI DEPOSITS (11)}

Three small mercury deposits have been found on the hillside south of Salihli, and although two of these have yielded a few flasks of mercury, the outlook for further production is not promising.

The Kursunludere deposit, $5 \mathrm{~km}$ south-southwest of Salihli, was mined on a small scale in 1969 and 1970, producing less than 20 flasks of mercury. Cinnabar occurs in small quartz veins in fractures in mica schist along a fault zone over a distance of a little more than $100 \mathrm{~m}$. Gangue minerals include pyrite, marcasite, stibnite, arsenopyrite, and pyrrhotite.

The Çamur Hamam deposit, $4 \mathrm{~km}$ south of Salihli, yielded a few flasks of mercury in 1969. The ore occurrence and mineralogy here is identical to that of the Kursunludere deposit.

At Kokar Dere, $6 \mathrm{~km}$ southeast of Salihli, cinnabar occurs with pyrite in small quartz veinlets in fractures in schist, but there has been no production.

As the Salihli area is one of fairly dense population and easy access, it seems unlikely that any significant mercury deposit that crops out remains undiscovered.

\section{ALAŞEHIR AREA}

The Alaşehir area, which contains one mine with a modest production and a few prospects, is in the southeastern part of the Manisa province about $120 \mathrm{~km}$ due east of Izmir. The city of Alaşehir is south of the main Izmir-Ankara highway, from which it is readily accessible by $45 \mathrm{~km}$ of excellent road. The only productive mine is 3 $\mathrm{km}$ south of the city and $2 \mathrm{~km}$ east of Kozluca village.

The mineralized area is on the northern slope of the sharply dissected Alassehir Mountains, which here consist mostly of muscovitebiotite-garnet schists of Paleozoic age overlain by limestone of Mesozoic age (see fig. 16). Lenses of silicified and carbonatized rock enclosing remnants of serpentine and grains of chromite crop out in the mine area. This rock is believed to be altered serpentine, much like the silica-carbonate rock associated with many of the mercury deposits of the California Coast Ranges. Another similarity to the California area is the occurrence nearby of glaucophane schists.

Hot springs and mineral springs occur in the Alaşehir Valley, but none of these appears to have deposited any mercury minerals.

\section{ALAŞEHIR MINE (12)}

The Alaşehir mine, sometimes referred to as the Orse mine from the first names of its owners Orhan Çutay and Sefer Aytekin, is on a 

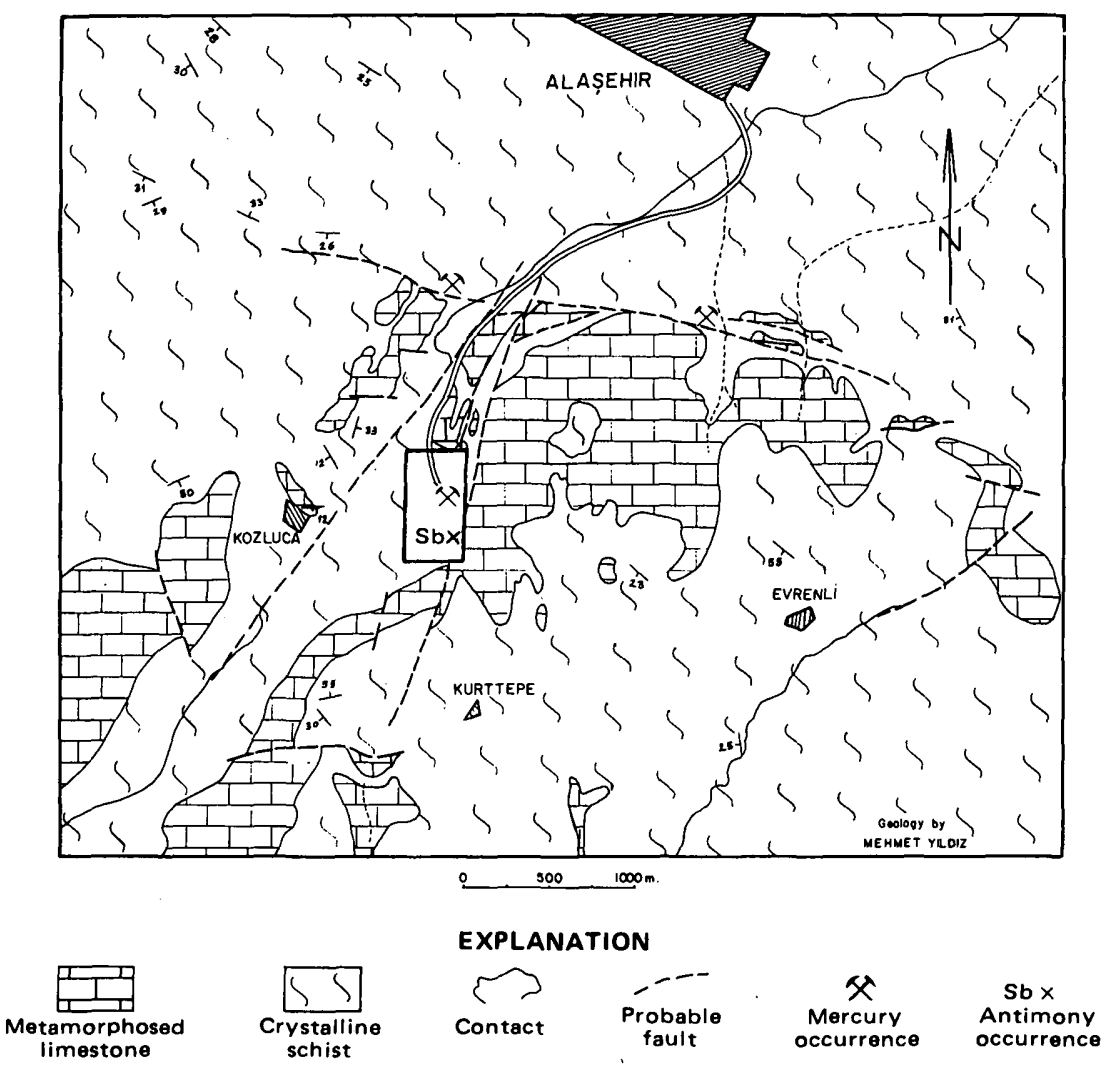

FiguRE 16.-Geologic map of the area south of Alaşehir showing the location of mercury and antimony deposits and outline of the Alaşehir mine area.

ridge about $3 \mathrm{~km}$ south of the city of Alaşehir and about $500 \mathrm{~m}$ above it. It is reached by an unimproved very steep jeep road that follows a ridge between two sharply incised valleys.

The mineralized ridge is underlain chiefly by schist (see fig. 17). Much of the ore, however, occurs in lenses of siliceous rock, which is mostly silica-carbonate rock derived from serpentine, but some could be silicified limestone. The siliceous rock has an arcuate outcrop pattern suggesting a synclinal fold, and the few measurements of the foliation of the schist support this inference.

Cinnabar, the only ore mineral, occurs as veinlets, fracture fillings, and thin lenses to $20 \mathrm{~cm}$ long in schists; it is disseminated in $1 / 2-m$-wide gouge zones with sugary quartz; and it forms scattered crystals and fracture coatings in silica-carbonate rock. Pyrite is common, and marcasite less so. Stibnite and realgar are found in a 


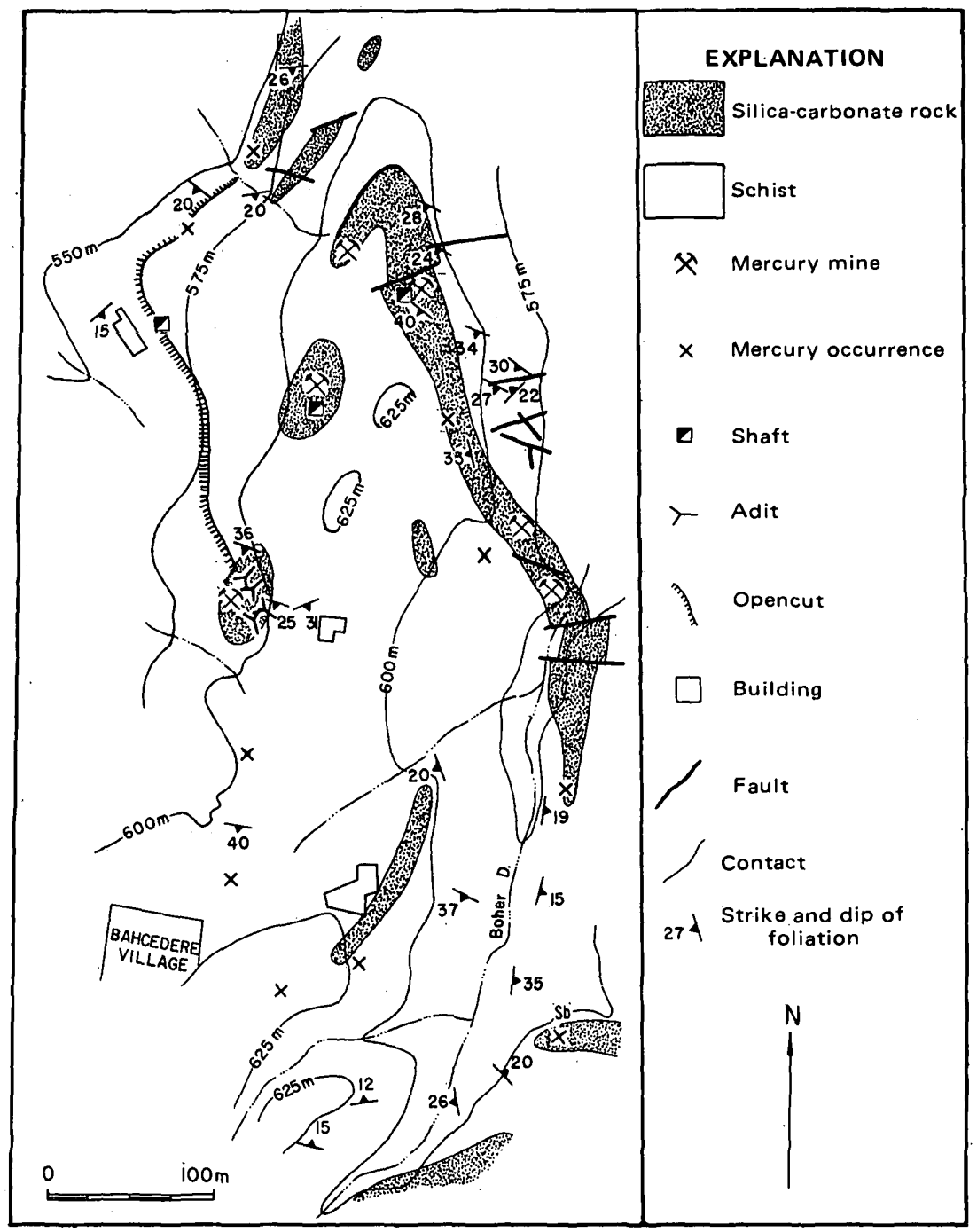

FigURE 17.-Geologic map of Alaşehir mine area.

small deposit nearby but have not been identified in the mercury ores.

Mining has been done in irregular pits to $10 \mathrm{~m}$ wide and, to a much lesser extent, by stoping from an adit that is about $80 \mathrm{~m}$ long. Both the small ore lenses and the larger gouge zones strike N. $50^{\circ}$ $60^{\circ} \mathrm{E}$. and dip moderately to the southeast. The mined ore was hand sorted to a grade between 0.4 and 4.0 percent and processed in three two-pipe inclined retorts made of iron pipe $50 \mathrm{~cm}$ in diameter and about $3 \mathrm{~m}$ long (figs. 18, 19). The mine was discovered in 1962 and 
has been producing since 1964 at a rate of about 25 flasks a month, working about 300 days a year. Its total recorded production through 1974 is 2,146 flasks of mercury, but apparently several

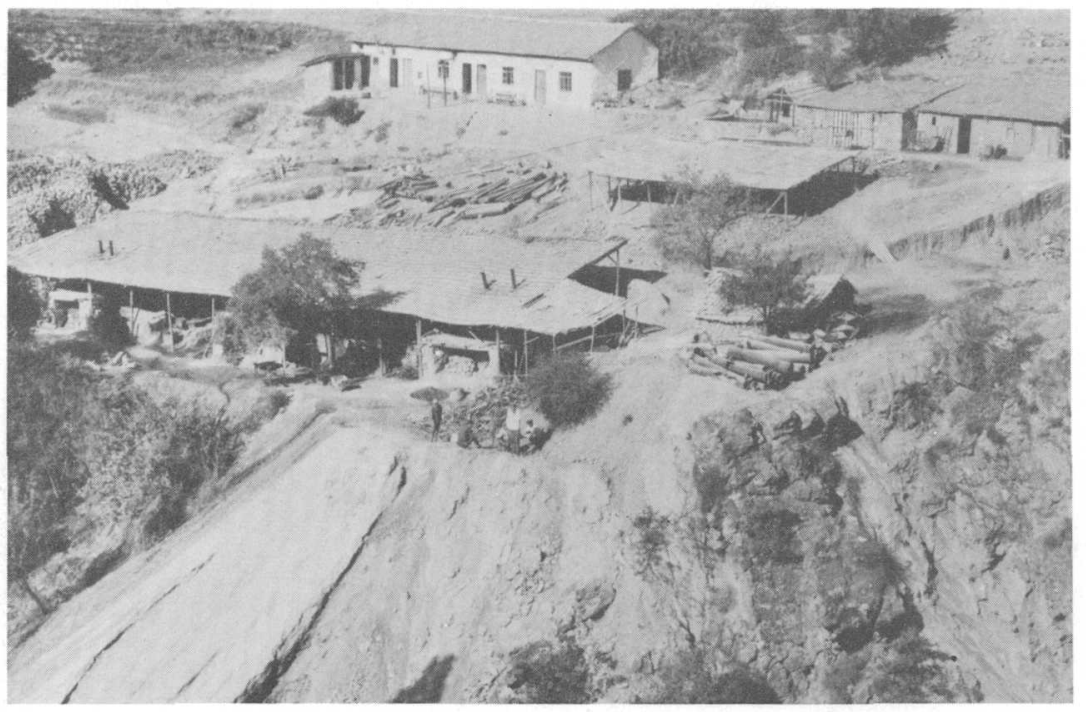

Figure 18.- View of Alaşehir mine camp and retort area, 1966. Burnt ore dump in foreground; discarded corroded retort pipes in pile beneath tree to right of center.

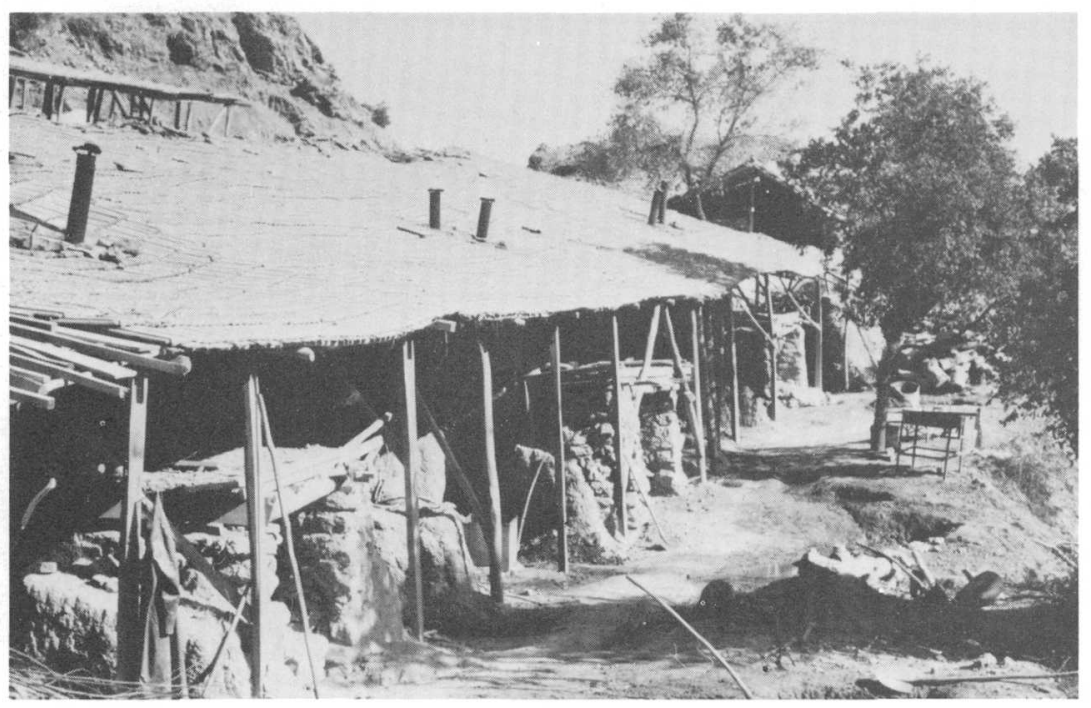

FIGURE 19.-Bank of retorts in use at the Alaşehir mine in 1966. 
hundred additional flasks of production were not recorded.

At least two other occurrences of mercury ore have been found: one about $1 \mathrm{~km}$ to the northwest and another $1 \mathrm{~km}$ northeast of the main mine. Southeast of the mine there is much silicified and ironstained rock, but apparently it does not contain appreciable quantities of mercury.

\section{MURAT DAĞI AREA}

The Murat Daği area, which has come into prominence as a mercury-producing area only since 1965 , occupies nearly $250 \mathrm{~km}^{2}$ of northern Uşak province, with its center about $35 \mathrm{~km}$ northeast of Uşak and $15 \mathrm{~km}$ northwest of Banaz (fig. 20). The area contains at least 23 occurrences of mercury ore, of which 7 support producing mines. Also within the area are several iron mines, some very close to the deposits of mercury. A few kilometers north of the area are

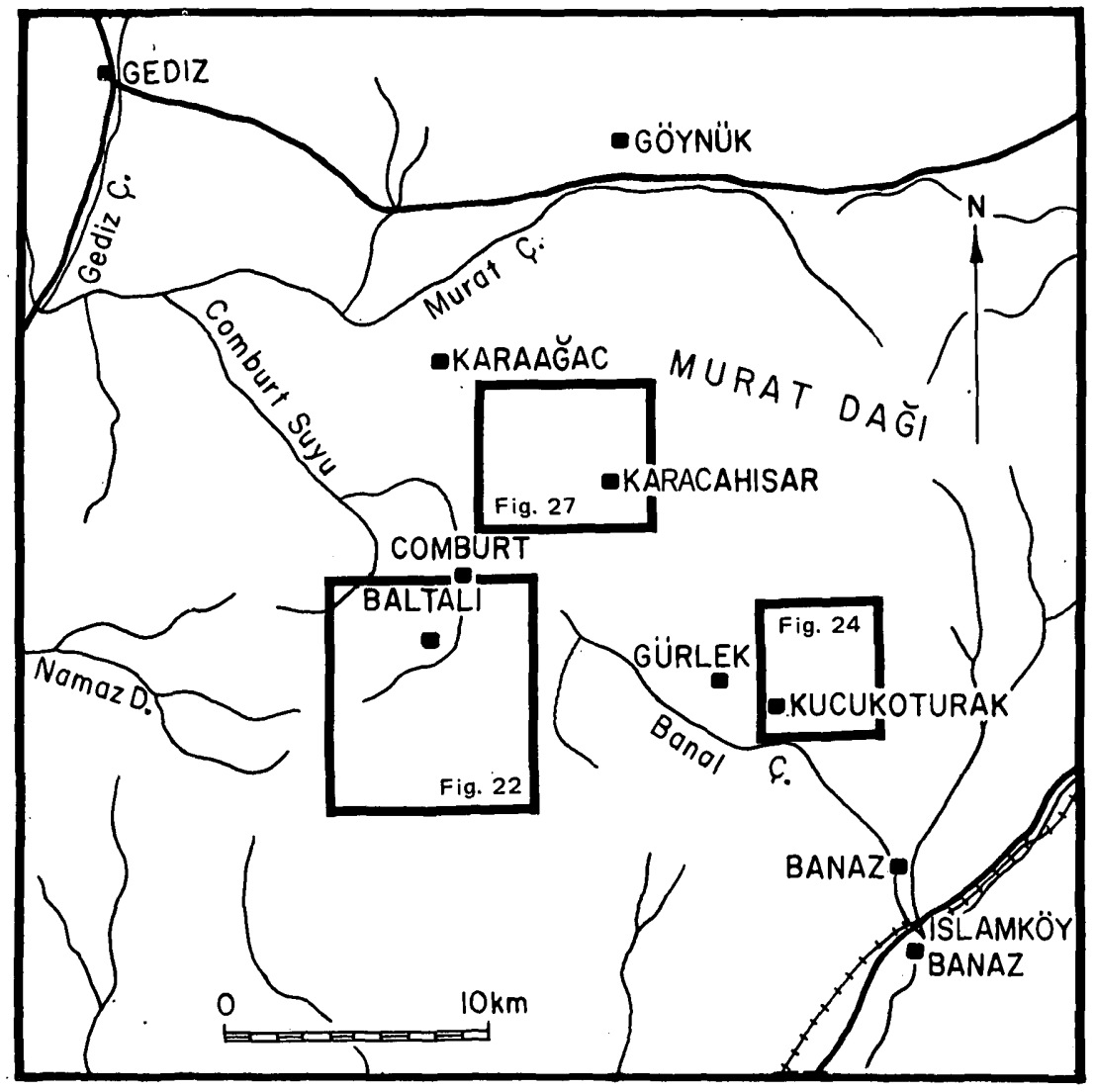

FIGURE 20.-The Murat Daği area northwest of Banaz showing areas covered by geologic maps of mercury occurrences (figs. 22, 24, 27). 
several producing antimony mines, but there is virtually no overlap in the mercury and antimony mineralization. Most of the terrane is mountainous and covered by pine forest; some of the mines are in more open foothills.

The oldest rocks of the area are quartzite, phyllite, schist, dolomitic limestone, and marble of Jurassic age, which are strongly folded. These rocks are intruded by great masses of Cretaceous serpentine that occupy one-third of the area. Some of the serpentine is altered to silica-carbonate rock, in other areas a common host rock for cinnabar ore but here only locally mineralized. Granodiorite of Paleocene age (E. Bingōl, oral commun., 1975) intrudes the metamorphic rocks in the northeast part of the area. The preTertiary rocks are overlain by a broadly folded early Tertiary sequence that begins with serpentine-rich conglomerate lying on serpentine, and continues upward through normal conglomerate, sandstone, and siltstone. Overlying them is a late Tertiary continental sequence of silicic flows and tuff, shale, sandstone, conglomerate, and limestone. Rhyolite, dacite, and trachyte, together with their pyroclastic equivalents, occur in the western part of the area; locally they are converted to opalite, which contains some of the mercury ore bodies. At least two sets of faults cut the rocks; the older set trends eastward and is cut by a prominent set trending northeast or north-northeast.

Most of the mercury deposits are in silicified rocks: silicified serpentine, conglomerate, rhyolitic or dacitic tuffs (opalite), and silicified limestone. Mineralization closely follows silicification and minor fracturing; openings along major faults are mostly filled with silica and do not contain mercury minerals.

Some of the deposits were mined many years ago, but no data regarding this period of mining are available. The first modern production came from the Baltali mine, and the other deposits were brought into production during the period of high mercury prices in the mid-1960's. In 1972 a 150-tpd rotary furnace was installed by the Turkish Mercury Corp. near the town of Banaz (fig. 21), and late in the year it began production on ore hauled from the Baltali Maden Sivrisi Tepe, Kestanelik Tepe, and Intepe mines. In 1975 production ceased and the assets of the company were taken over by Etibank. The total production of the area is believed to be more than 2,000 flasks.

\section{BALTALI GROUP (13)}

The Baltali group is made up of the scattered Maden Sivrisi Tepe, Çakiraz Tepe, and smaller Satilmiş Tepe mines about $2 \mathrm{~km}$ west and south of the village of Baltali (see fig. 22). The village is readily accessible from Banaz on the Uşak-Afyon highway by $30 \mathrm{~km}$ of 


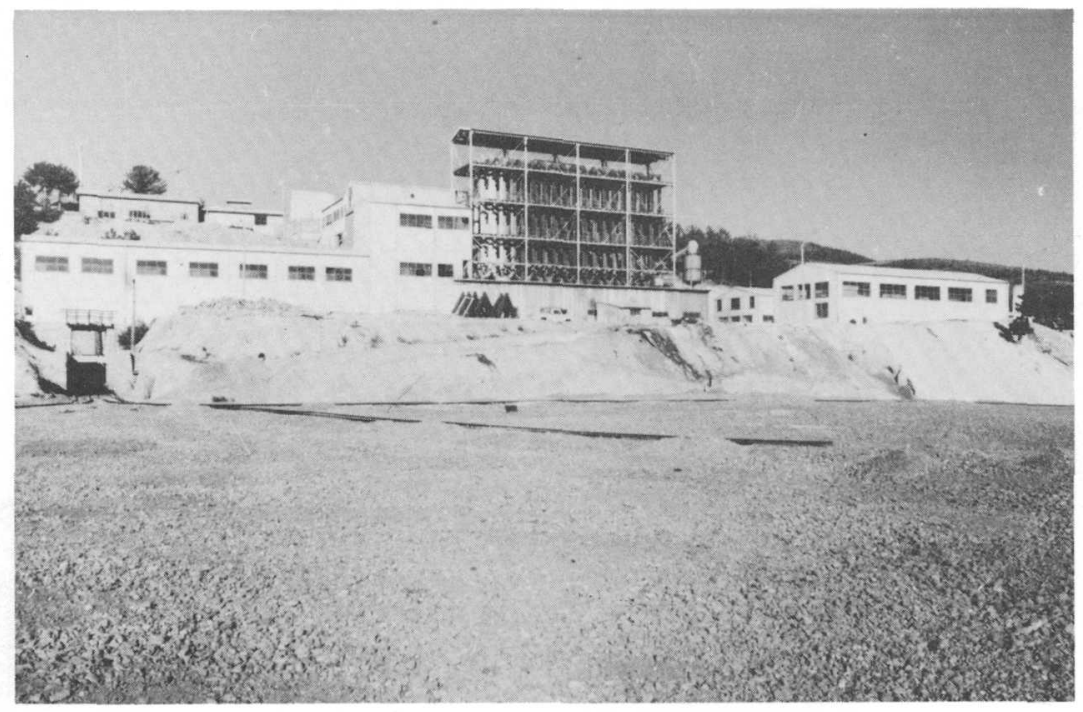

FIGURE 21.-The 150-tpd rotary furnace plant installed near Banaz by the Turkish Mercury Corporation in 1972. Photograph taken in 1973 from flat top of burnt ore dump in foreground.

gravel road, and short branch roads lead to the different deposits.

The Maden Sivrisi Tepe mine is in an area of nearly flat-lying siliceous flows and tuffs locally silicified by impregnation of quartz, chalcedony, and opal to form a rock referred to as opalite. Cinnabar forms ore in this rock where it fills irregular open spaces, fractures, and cracks; minor cinnabar also occurs in unsilicified tuff. A little iron stain and jarosite accompany the ore, but iron sulfides have not been seen in the near-surface ore. In the layered volcanic rocks, three beds are most intensely silicified, and margins of vertical fractures in soft tuff beds between them are silicified. The cinnabar is concentrated in three overlapping ore bodies in the three siliceous zones. The blankets of good ore are 1 to $3 \mathrm{~m}$ thick and at least $60 \mathrm{~m}$ in horizontal extent (fig. 23). The margins above and below are rather abrupt, and the less altered tuff between layers contains little cinnabar.

The mine is an old one with more than a thousand meters of underground workings from which ore yielding perhaps as much as 1,000 flasks was mined. In 1970 the Turkish Mercury Corp. was organized, and in a joint venture with Etibank began exploration and development of the deposit. In 1972, after a 150-tpd rotary furnace plant had been completed at Banaz, the deposit was mined in an opencut by power shovel, and the ore was hauled the $30 \mathrm{~km}$ to the new furnace. The grade of the ore is quite low, but reserves are es- 


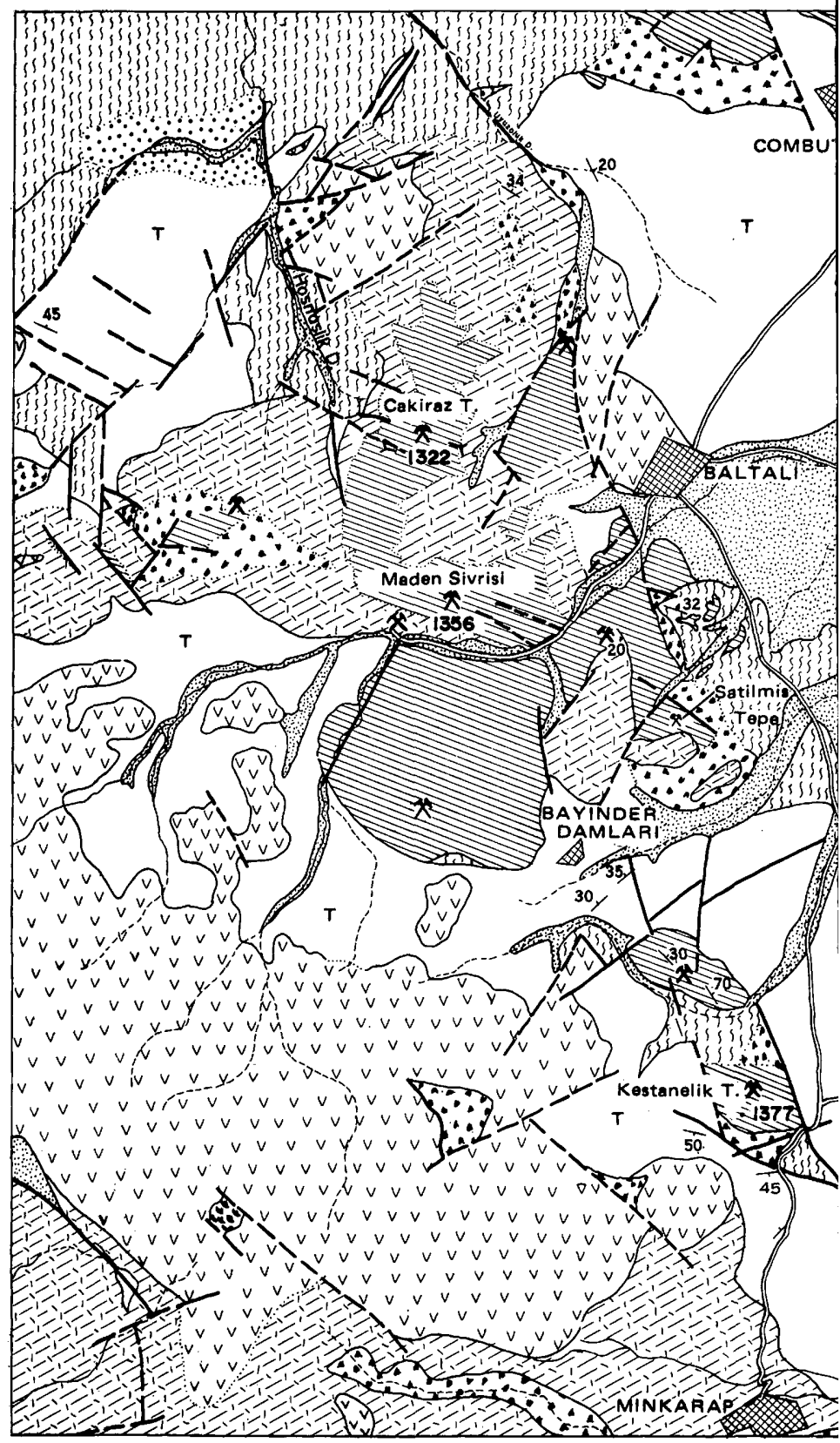

Figure 22.-Part of the Murat Daği area showing the geologic setting of the Maden 


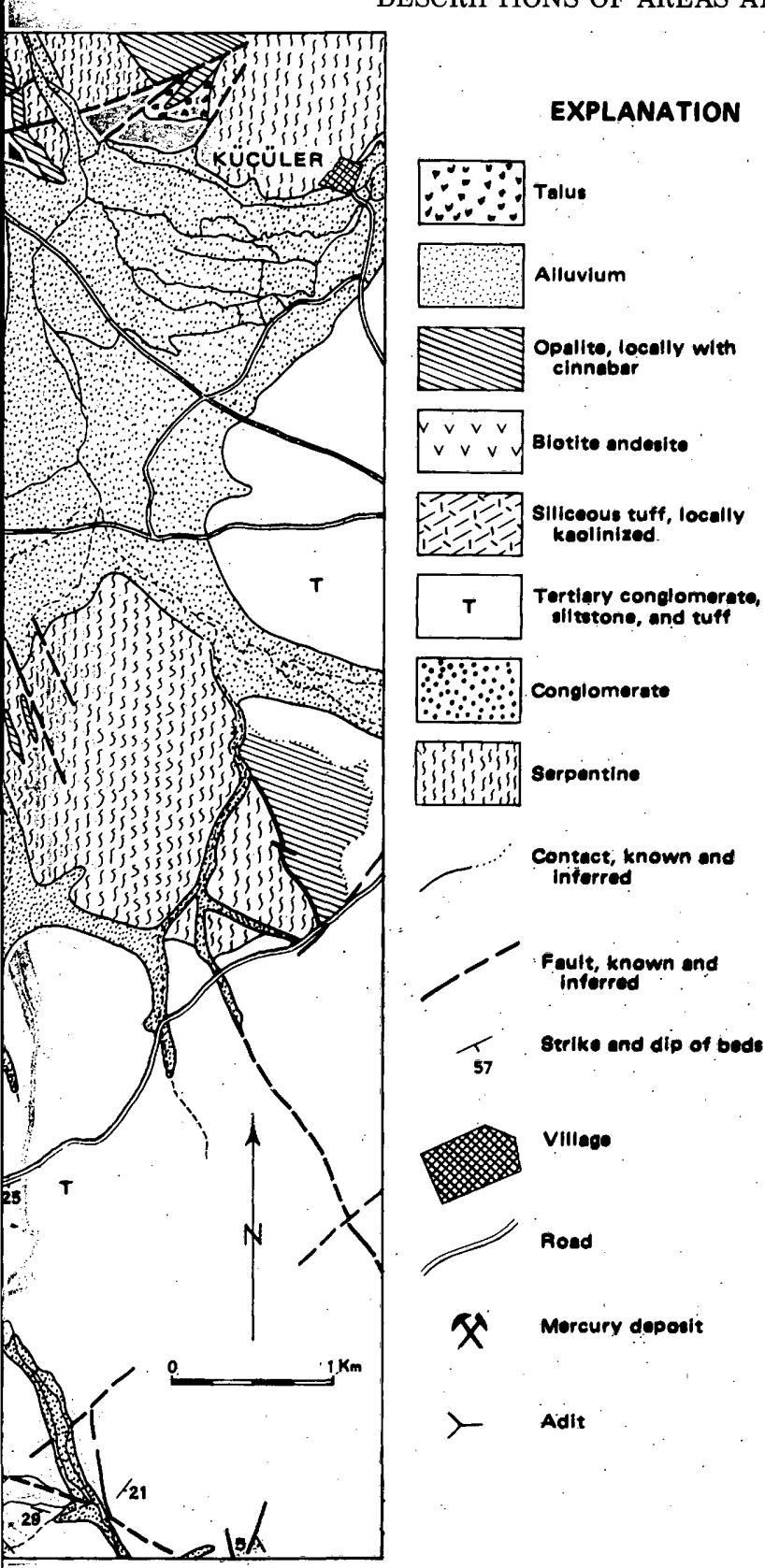

Sivrisi Tepe, Çakiraz Tepe, Satilmiş Tepe, and Kestanelik Tepe mercury mines. 


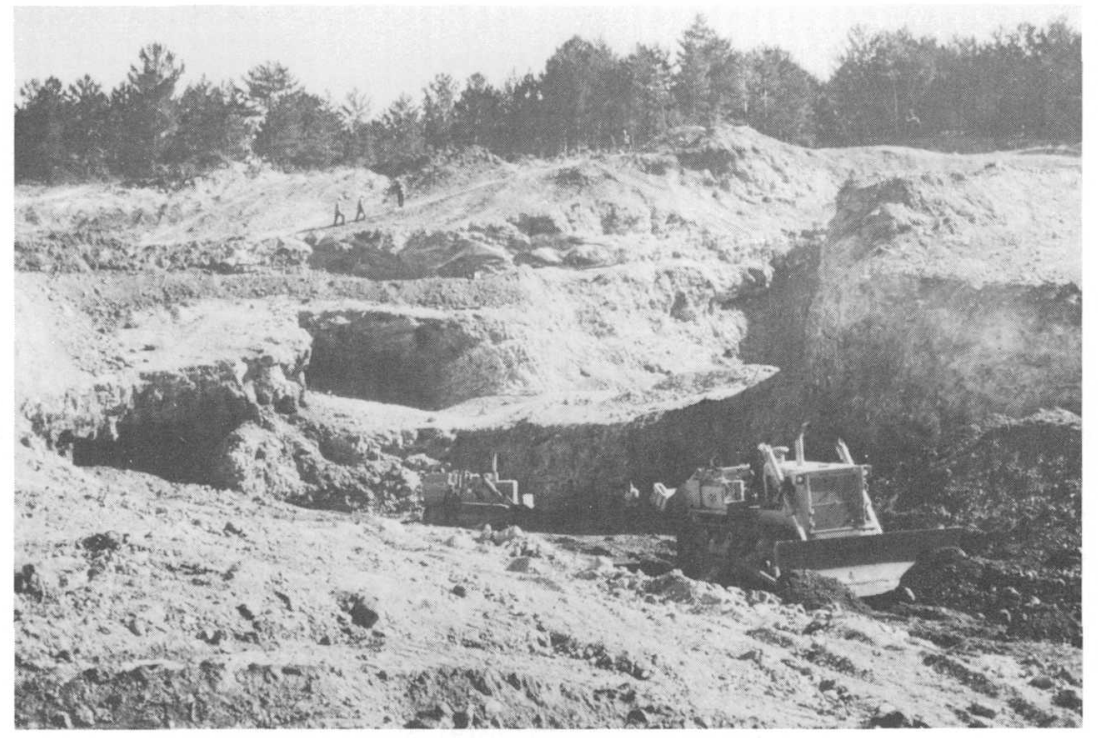

Figure 23.-Opencut developed in gently dipping opalite at the Baltali Maden Sivrisi Tepe mine.

timated to be large. As the ore from the Maden Sivrisi Tepe mine was mixed with ores from other deposits, the total production of the mine is not known.

The Çakiraz Tepe deposit, which is part of the Baltali group of mines, is about $1 \mathrm{~km}$ north of the Maden Sivrisi Tepe deposit (fig. 22 ). It is in an area of deep soil and forest cover, but the dump reveals the presence of both silicified and argillized tuff and breccia. Cinnabar occurs as thin coatings and veinlets accompanied by considerable pyrite. Weathered ore contains much jarosite. Long ago an adit was driven in an area beneath small surface cuts, and since the mine's revival in 1968, two additional long adits have been driven. The ore is low grade, probably less than 0.2 percent, and is hauled for processing to the furnace plant near Banaz.

\section{KESTANELIK TEPE MINE (14)}

The Kestanelik Tepe mine is a minor deposit on a low hill about 3 $\mathrm{km}$ south of Baltali in the southwest corner of the Murat Daği area (fig. 22). Here cinnabar forms ore containing about 0.5 percent mercury where it is concentrated with silica in openings in silicified and brecciated quartz-pebble conglomerate of late Tertiary age. Some lower grade ore occurs beneath the conglomerate where cinnabar is disseminated in sandstone. The deposit was mined on a small scale some years ago, but there is no record of early production. In 1972 
the Turkish Mercury Corp. began mining in an open pit and hauling the ore to its 150-tpd furnace plant in Banaz.

INTEPE MINE (15)

The Intepe mine is in the southeastern part of the Murat Daği area and accessible by road from the village of Kuçükoturak, about $10 \mathrm{~km}$ northwest of Banaz (fig. 24). The ore consists of disseminated cinnabar in a moderately silicified conglomerate with some

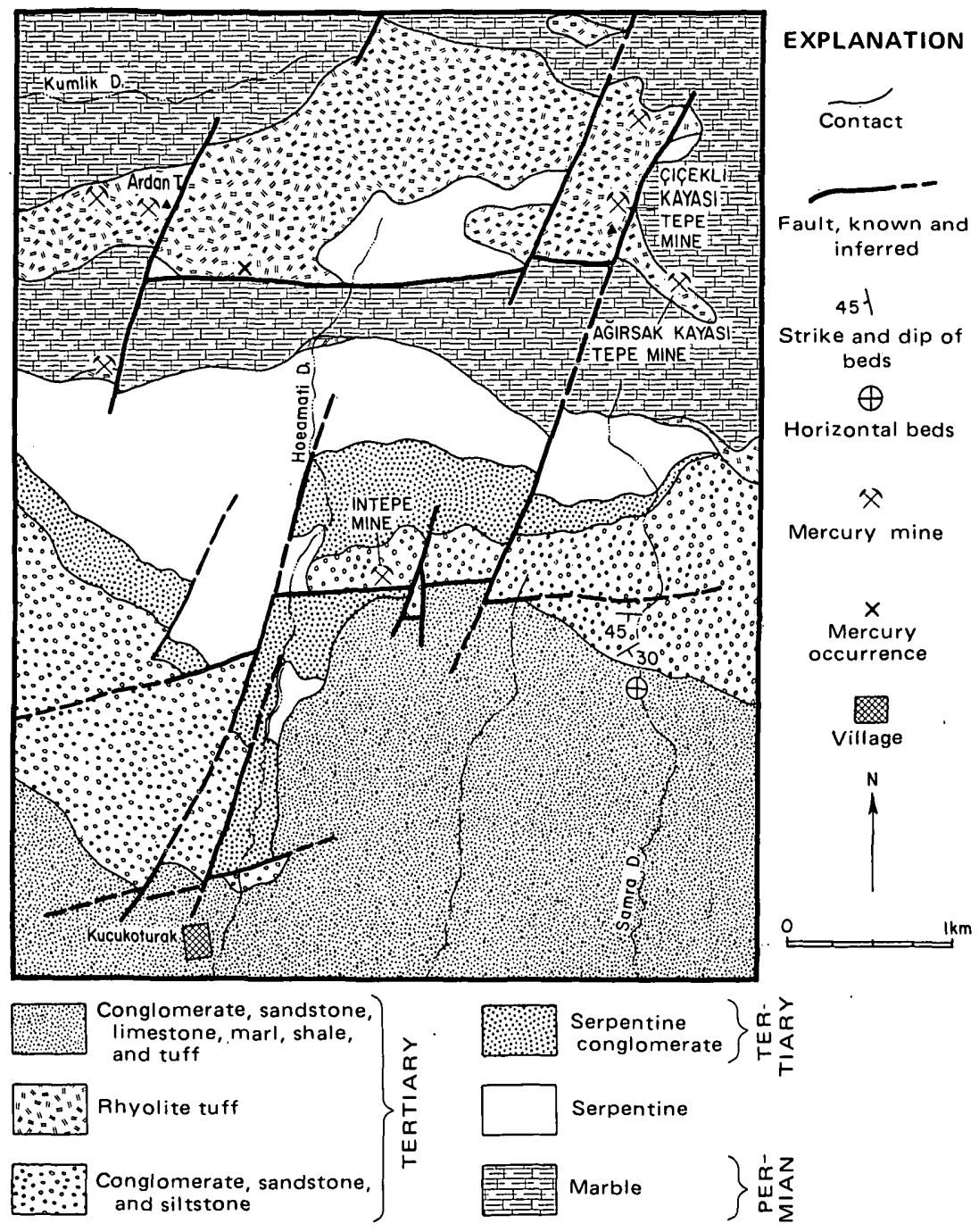

FIGURE 24.-Geologic map of an area including the Intepe, Çiçekli Kayasi Tepe, and Ağirsak Kayasi Tepe mines. 
sandstone. Both pyrite and marcasite have been identified in some of the ore. Serpentine lying below the conglomerate is unmineralized. Mining has been done mostly on the surface, but there are a few hundred meters of tunnels and a shaft. In the period 1968-71, a private company operated the mine and, by retorting sorted ore containing 0.5 percent mercury, obtained about 350 flasks of mercury. In 1972 the deposit was leased to the Turkish Mercury Corp., but in the following year, when no major ore body had been found, the lease was not renewed.

\section{ÇIÇEKLI KAYASI TEPE MINE (16)}

This deposit takes its name from its occurrence in a very steep and sharp white peak, Çiçekli Kayasi Tepe, that looms above an area of dense pine forest (fig. 25). It is $14 \mathrm{~km}$ north-northwest of Banaz, from which it is reached by a $27-\mathrm{km}$-long road (fig. 24).

Very fine grained cinnabar occurs as clouds of disseminated particles in chalcedony, and very locally as richer quartz-cinnabar veinlets in partly brecciated but very hard silicified rock that may be either totally replaced limestone or a hot-spring sinter deposit. Ore was restricted to two or three vertical pipes 5 to $7 \mathrm{~m}$ in diameter which have been mined to a depth of $30 \mathrm{~m}$ (fig. 26). The pipe walls are locally smooth and fluted and perhaps are the vents for hot springs that deposited the sinter. Unfortunately, at the time of our visit, all of the filling of the pipes in this geologically interesting deposit had been mined out. It appeared that attempts made to mine the red rubble on the hillside around the siliceous knot had been unsuccessful.

The deposit here was discovered in 1962 and has been mined by a private company from 1965 to 1971 . Most of the mining has been done in a narrow pit served by an underlying haulage adit, but some ore has been mined underground through several other workings totaling only a few hundred meters in length. The ore is reported to have been hand sorted to a grade of 0.5 percent or more mercury and to have been hauled by truck to retorts at Uşak, some $72 \mathrm{~km}$ away. The total production is rumored to be about 1,000 flasks of mercury, but to yield this amount, the ore must have been very much richer than any we have seen.

\section{AĞIRSAK KAYASI TEPE (17)}

A small deposit on the peak of the Agirsak Kayasi Tepe is about $800 \mathrm{~m}$ south of the Ciçekli Kayasi Tepe mine and can be reached from Banaz over the same roadway (see fig. 24). The ore deposit is somewhat similar to the Çiçekli Kayasi Tepe deposit, the cinnabar occurring in a brecciated hard silicified rock. The siliceous breccia 


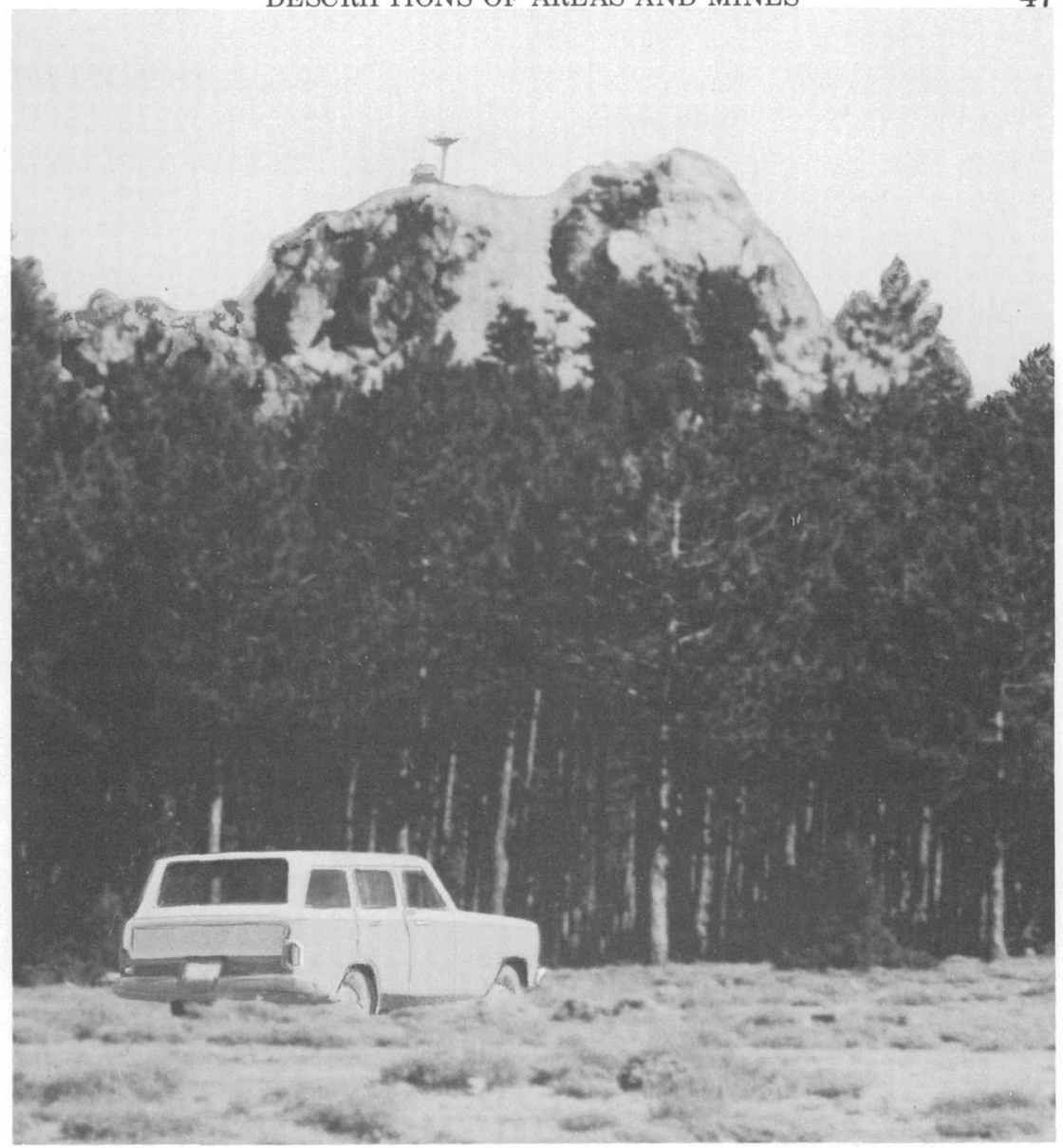

FIGURE 25.-Looming above the forest is the spire of siliceous sinter(?) that contains the Çiçekli Kayasi Tepe ore deposit.

directly overlies unaltered limestone and appears to be a siliceous sinter, but although some cinnabar was concentrated in steep fractures and rubble zones, we were unable to identify any ancient spring vents like those at Çiçekli Tepe.

The deposit was discovered in the mid-1960's and was mined in an open pit by a private company. Hand-sorted ore was hauled $22 \mathrm{~km}$ to retorts at a site north of the village of Banaz Köy, but the total production is small, perhaps around 50 flasks. Little cinnabar remains, and the deposit appears to have been mined out.

\section{KARACAHISAR MINE (18)}

The Karacahisar mine is near the middle of the Murat Daği area, about $25 \mathrm{~km}$ by road from Banaz. The main deposit is near a valley, 
but mercury mineralization extends discontinuously to the northwest almost a kilometer up the slope of Tozlakğedik Tepe, where

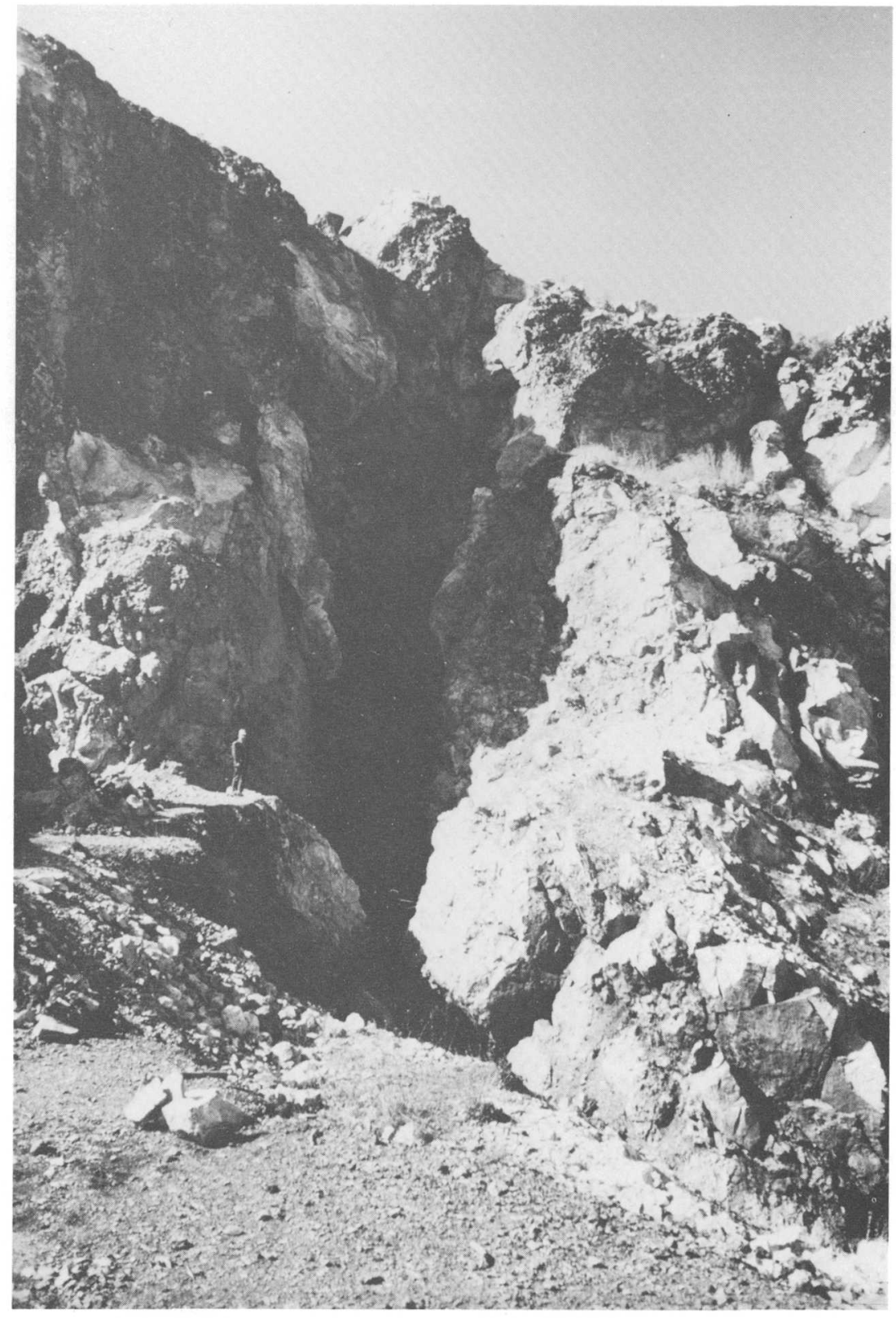

Figure 26. - Mined-out ore pipe in siliceous rock (sinter?) at Çiçekli Kayasi Tepe mine. Person standing on flat surface to left of pipe provides scale. 
there formerly was a small mercury mine by this name (see fig. 27).

The Tozlakgedik Tepe deposit was largely in silicified and brec-

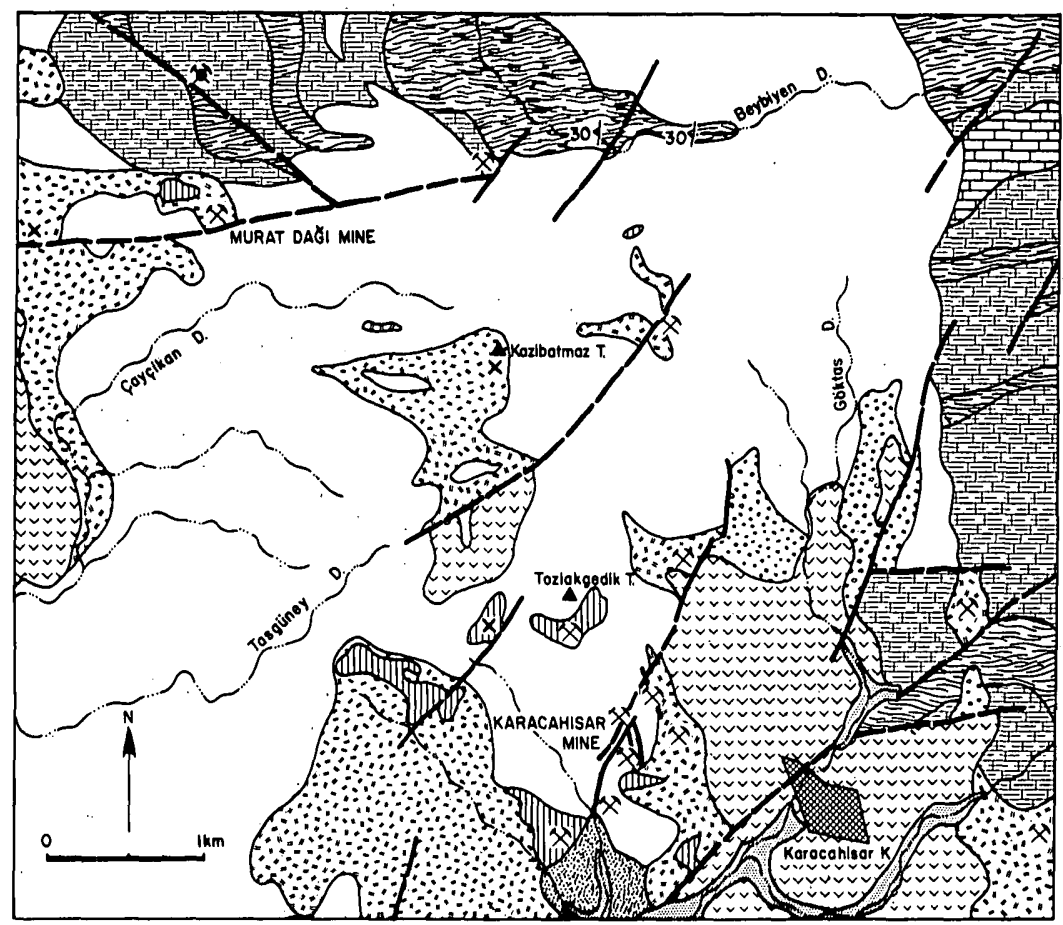

EXPLANATION

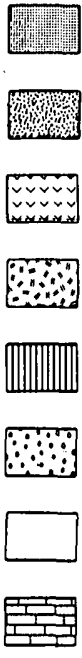

Alluvium

Conglomerate, sandstone, limestone, morl, shale, and tuff

Andealte, decite, and

trachyte endesite

Rhyollte tuff

Sillca-carbonate rock

Conglomerate, sandstone,
and siltstone

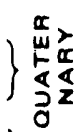

$x$
$w 2$
5
$x$
2
0

Marble

Phyillite and cryatalline schist

Serpentine

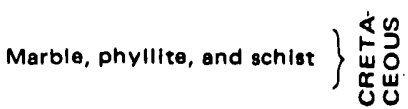

- Contact

告

_. Fault, known and inferred

32. Follation

x Mercury mine

x Mercury occurrence

3. Antimony mine

Village

FIGURE 27.-Geologic map of the Karacahisar mine area. 
ciated rhyolite tuff. From there down to the main deposit of the Karacahisar mine, cinnabar occurs in various places in fissures and disseminated in intensely silicified serpentine, regarded as a kind of silica-carbonate rock. Pyrite and marcasite are abundant in the ore in the silica-carbonate rock but unknown in the ore in rhyolite. The mineralization of the lowest deposit is partly controlled by a fault that trends N. $30^{\circ}$ E., following the valley, and it is likely that some of the other poorly exposed deposits lie along similar faults. Other smaller faults trending northwest appear to be unmineralized.

The Karacahisar deposit was first worked by a private company in the mid-1960's by opencut mining. Ore was hand sorted to achieve a good grade and treated in retorts at the mine. The total production is believed to be about a hundred flasks. Production from the other deposits nearby is unknown but believed to be small.

\section{EVRENTDEDE DEPOSITS (19)}

The Evrentdede mercury area contains two main deposits, both in silicified serpentine (figs. 28, 29). At the Kumçam deposit, $5 \mathrm{~km}$ north of Banaz, the mineralization consists of an east trending zone containing narrow but rich veinlets of cinnabar traversing the silicified serpentine (fig. 28). The ore was intially mined from the surface; in 1970 underground mining was started. The ore is treated in retorts near the mine.

The other deposit, named Hasan Dami, is several kilometers to the west and can be reached from Banaz over $20 \mathrm{~km}$ of jeep road. Cinnabar veinlets striking N. $30^{\circ} \mathrm{W}$. and other concentrations of scattered crystals occur in silicified serpentine. Much of the ore is in a deeply weathered ocherous cellular rock formed by leaching out the carbonates from a silica-carbonate rock. The mine is an old one with surface pits, an adit, and at least two shafts, one of which is said to reach a depth of $80 \mathrm{~m}$. After a long period of inactivity, mining was resumed in 1968 and continued for at least 6 years. Handsorted ore was treated in six retorts; each contained four iron pipes and had water-cooled condensing pipes (fig. 30). Lignite was used for fuel. Production was said to amount to 200-300 flasks per year, but the recorded production from $1968-73$ is only 772 flasks.

\section{IVRINDI AREA}

\section{IVRINDI OCCURRENCES (20)}

In Balikesir province, a few occurrences of cinnabar have been found about $6 \mathrm{~km}$ south of Ivrindi and $30 \mathrm{~km}$ southwest of the city of Balikesir (Marico, 1970). Except perhaps for the recently discovered Savaştepe deposit described below, they are of no apparent economic interest. 


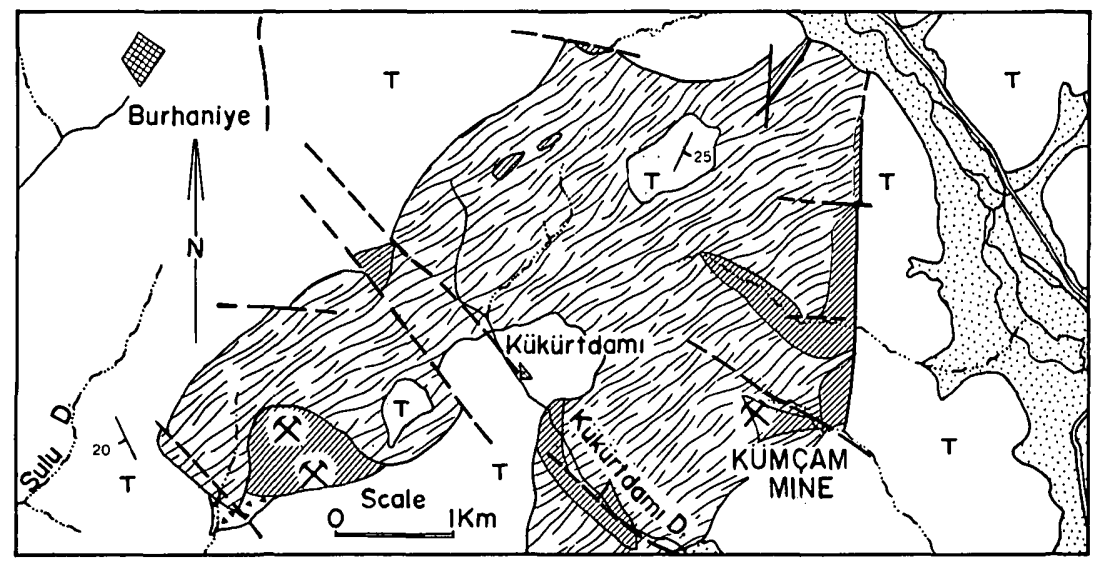

EXPLANATION
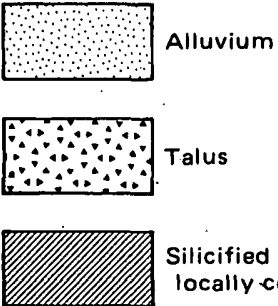

Talus

Silicified rock.

locally contains cinnabar

Serpentine

Tertiary conglomerate, sandstone, clay, marl, and local tuff beds

X Mercury occurrence

\section{$\leadsto$ Contact}
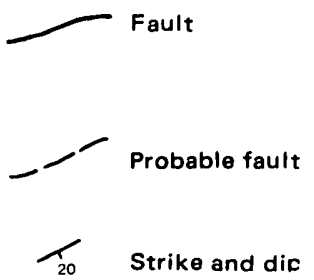

Road Village

Figure 28.-Geologic map of the area about the Evrentdede mercury deposits.

The Ivrindi area is underlain by Paleozoic (Permian?) limestone and Tertiary andesite, rhyolite, and pyroclastic equivalents. Cinnabar occurs in three places along north-trending fractures in silicified limestone, but its apparent extent in each place is only a few meters in length and $20 \mathrm{~cm}$ in width. Elsewhere in the area are promising antimony deposits consisting of disseminations and veins of stibnite in highly argillized andesite. The antimony and mercury have not been found together.

In 1974 the Savaştepe mercury deposit was discovered about 30 $\mathrm{km}$ southwest of Balikesir. In this area cinnabar occurs in silicacarbonate rock bordering a contact between serpentine and 


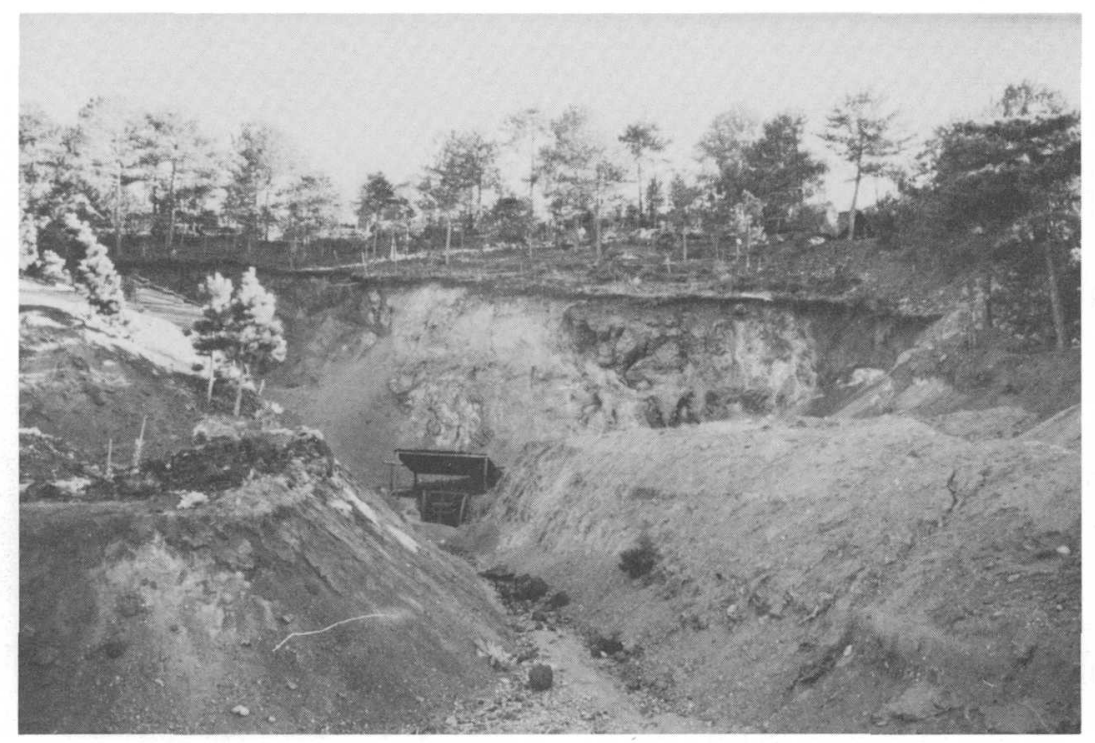

FiguRE 29.-Evrentdede mine portal in weathered silica-carbonate rock.

sandstone. The mineralized zone is several meters wide and extends along a strike at least $25 \mathrm{~m}$ to where the contact is covered by andesite. As other silica-carbonate zones occur over an area of 1 to $2 \mathrm{~km}^{2}$, this region warrants further investigation.

\section{BIGA AREA}

The Biga area, in the northern part of the Balikesir province only about $20 \mathrm{~km}$ south of the southern shore of the Sea of Marmara, is chiefly an area of base-metal deposits. Mercury was first discovered there in 1969, and by 1972, when the low price of mercury forced the termination of mining, perhaps 200 flasks of mercury had been recovered. The area is one of considerable relief and is heavily forested, making for difficult prospecting. It is also notable because of the prevalence of earthquakes and active hot springs.

\section{HODUL KÖY MINE (21)}

The small Hodul Köy mine lies at an altitude of about $400 \mathrm{~m}$ in the mountains midway between Biga and Gönen. It can be reached by driving $12 \mathrm{~km}$ over a road extending south from the ÇanakkaleBursa highway. The rocks of the area include Paleozoic phyllite, quartzite, and schist overlain by Mesozoic (Jurassic?) limestone and capped by Tertiary andesite, dacite, and related tuffs (fig. 31).

Cinnabar and some native mercury occur in veinlets with quartz and pyrite along fractures and faults in a Paleozoic graphitic schist 


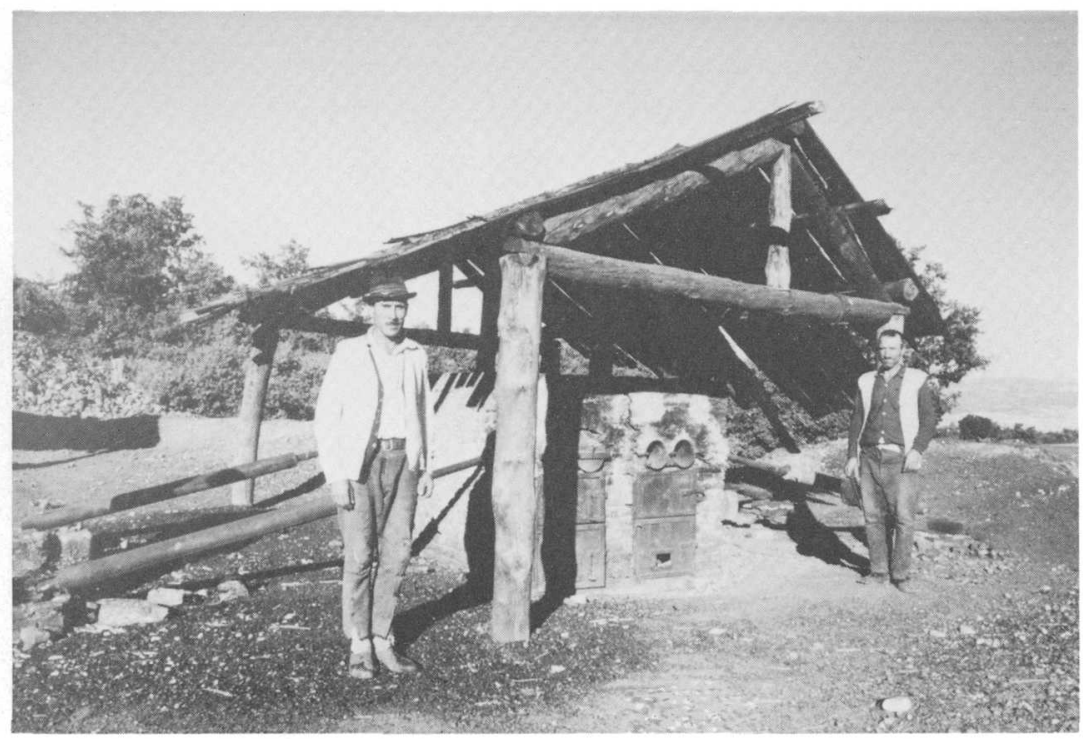

Figure 30.-One of six 4-pipe retorts being used in 1973 to treat ore from the Evrentdede mine.

and in the Mesozoic limestone close to the younger volcanic rocks. Some ore was taken from an open pit, and some came from a few hundred meters of underground workings. By 1972, after production ceased with the lowering of the price of mercury, 65 flasks had been produced through retorting of hand-sorted ore. Although the deposit appears to be small, it is a new discovery in an area not previously known to contain mercury ore. Additional search for other deposits in this region seems warranted.

\section{IZMIT AREA}

In the Izmit area $45 \mathrm{~km}$ east of Istanbul, there are a few small mercury deposits, only one of which has had a little production. The rocks here are limestone, arkosic sandstone, and conglomerate of Paleozoic age that are poorly exposed through a cover of soil in an oak forest.

\section{MUDARLI MINE (22)}

The Mudarli mine, a few hundred meters northeast of the village of the same name, is accessible from the Istanbul-Ankara highway via $44 \mathrm{~km}$ of jeep road. Cinnabar occurs here in veinlets with quartz and a little pyrite in limestone and dark arkosic sandstone, and to a lesser degree as grains and patches disseminated through these rocks. Höll (1966) believed the mercury ore to be syngenetic, but it 

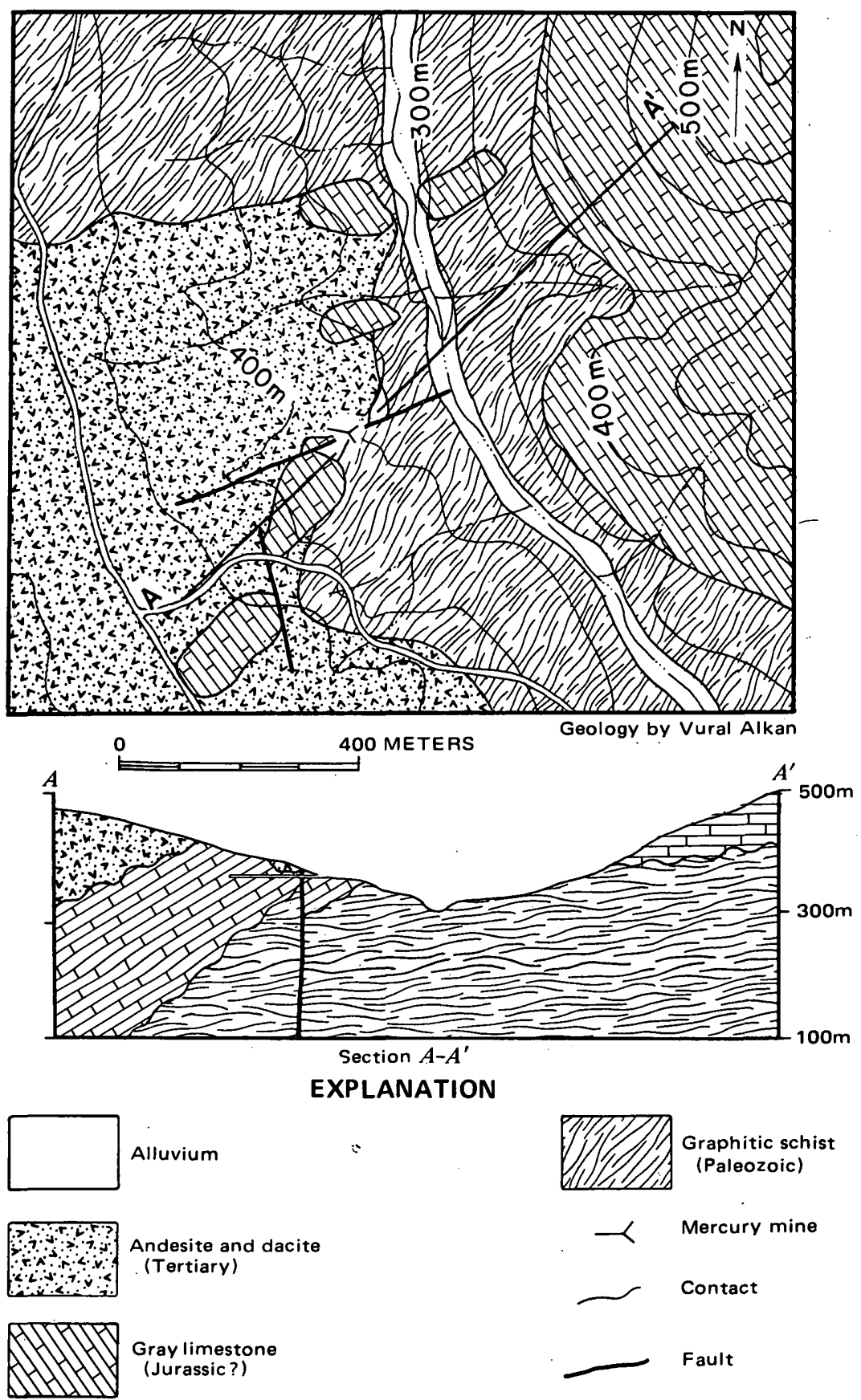

Figure 31.-Geologic map and section of Hodul Köy mine area. 
clearly is in veins not confined to one stratigraphic horizon and seems more likely to be hydrothermal in origin. Erosion of the primary deposits and deposition in the nearby valley has given rise to placer concentrations, which were mined on a small scale sometime prior to World War I (MTA, 1970). The latest mining here was in 1967, and the total production is believed to be less than 100 flasks of mercury. Other occurrences in the area, though still poorly exposed, appear to have no economic value.

\section{SÖĞÜT AREA}

\section{SÖĞÜT OCCURRENCES (23)}

Two economically unimportant but geologically interesting occurrences of cinnabar have been found east of Sögüt, in Bilecik province, $33 \mathrm{~km}$ southeast of Bilecik. One occurrence is in the Korudanlik district $6 \mathrm{~km}$ east of Söğ̈̈t, where in 1971 a little cinnabar was found in cracks in silicified parts of a limestone bed. In the same area gold occurs with clay in apparent solution pockets in the limestone, in one place in amounts assaying $900 \mathrm{~g} / \mathrm{ton}$. The cinnabar and gold do not occur together, and no relation between them is suspected. The second occurrence is a discovery, also in 1971, of cinnabar in some exploratory trenches at the Dudas mine, $4 \mathrm{~km}$ north of the Korudanlik area. Here small amounts of stibnite and scheelite have been mined from quartz veins cutting schist and sandstone. The presence of cinnabar in this deposit was first reported by Höll (1966) but, until this new discovery, had not been seen by the mine operators.

\section{INEBOLU AREA}

The Inebolu area bordering the south shore of the Black Sea contains the Şeyhşaban mercury mine, which has had intermittent production for 60 years. The area is in the northern part of the Kastamonu province, township of Inebolu, and is by airline only about $25 \mathrm{~km}$ southeast of the seacoast port of Inebolu. However, the mine area is high in the Pontid Mountains and is most easily reached from Kastamonu via Devrekani and Şeyhşaban.

This part of the Pontid Mountains is formed of upper Paleozoic and Mesozoic sedimentary and volcanic rocks that have been folded and faulted during the Alpine orogeny. It contains many copper deposits, including the nearby Küre deposit (Bailey and others, 1967), but the Seyhşaban deposit is the only known occurrence of mercury minerals. Such an extensive deposit without some satellitic deposits along the same tectonic zone is unusual; additional search along this rugged belt might discover other deposits. 
ŞEYHŞABAN MINE (24)

The Şeyhşaban mine is reached from the village of the same name by traveling $2 \mathrm{~km}$ south toward Devrekani and here turning off to follow a branch road $7 \mathrm{~km}$ through Ahatlar to Terce, the location of the mine (fig. 32). Near the mine the road contours along the steep north slope of a valley $500 \mathrm{~m}$ or more deep, and at the mine there are pits and adits spread from the base of the valley up the slope for several hundred meters (fig. 33). An average altitude is about 750 $\mathrm{m}$, and winter snows at this level make year-around production difficult.

The rocks of the area (fig. 32) are not well exposed and the geology is not entirely understood. The area is underlain by irregular lenses of sandstone, shale, phyllite, conglomerate, and limestone which mainly strike east and dip south at intermediate angles. These rocks are cut by east-trending faults, at least some of which are low-angle thrust faults that dip northward. Apparently intruded along one of the fault zones are masses of serpentine, prominently exposed along the road by Ahatlar. Locally the serpentine has been altered to silica-carbonate rock, but no mercury has been found in this rock.

The only ore mineral in the Şeyhşaban deposit is cinnabar, which occurs with quartz in fractures in indurated shale and silicified and dolomitized limestone. Locally, in openings in the rock, the cinnabar occurs as well-formed euhedral crystals 1 to $2 \mathrm{~mm}$ in size. Stibnite is more abundant than cinnabar in the lowest ores near the canyon floor, and realgar occurs in some of the ore in higher exposures. The cinnabar is most aburidant beneath the faults dipping at low angles to the north, but no large or rich ore bodies have been found. As mined, the grade does not exceed 0.1 percent, but the ore is readily sorted by hand to achieve a better grade.

The deposit was first mined by a French company beginning in 1912, but neither the duration of their work nor the amount of production is well known. In 1956, after a long period of inactivity, the mine was bought by the Göksu Mining Co., which began producing in 1958 at a rate of a few hundred flasks a year. Most of their production came through the use of three $1 \frac{1 / 2}{2}$-ton upright furnaces constructed with a wood-burning firebox at the base, a central stovepipelike chimney which was loaded with charcoal, and a complex system of condensing troughs spread on the hillside above the furnace (fig. 34). Late in 1960 a modern 30 -foot oil-burning rotary furnace was installed, but owing to an inadequate condensing system, it was abandoned after only 7 hours' use. In 1971 a 50-tpd rotary furnace was installed, but production from it has been small. It is believed that the total production from the several deposits that make up the Şeyhşaban mine has been about 1,500 flasks. 


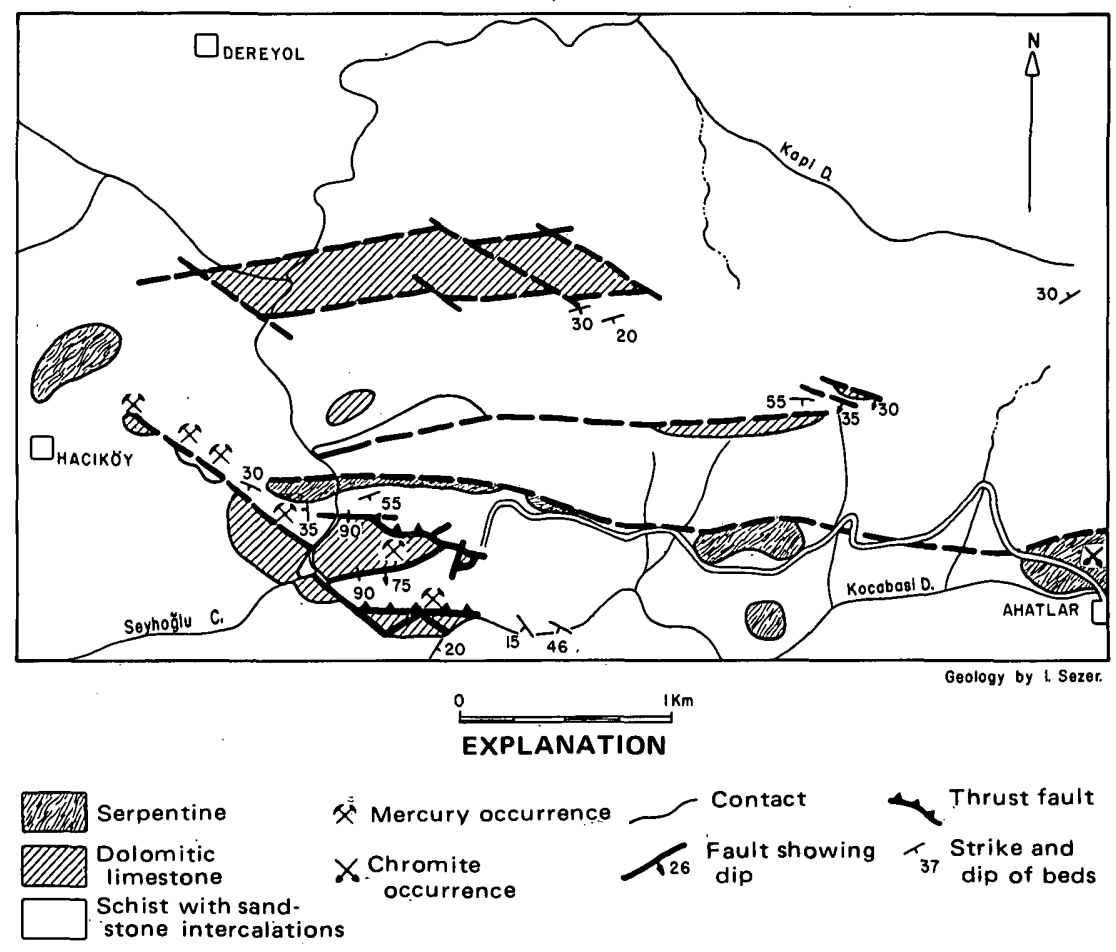

FIGURE 32.-Geologic map of the Şeyhşaban mine area.

\section{KONYA AREA}

The ore deposits of the Konya area have been the source of a third of all the mercury produced in Turkey, and they are of special interest because they probably were first worked for cinnabar to be used as "paint" more than 8,000 years ago. This area, $40 \mathrm{~km}$ northnorthwest of the city of Konya (fig. 1), is readily accessible from either the east or north by roads leading from the Konya-Afyon highway.

The area is dry and mountainous, with massive limestone ridges rising from the plain at $1,000 \mathrm{~m}$ to reach altitudes of about $1,900 \mathrm{~m}$ along a centrally located divide. The rocks of the area, believed to be Paleozoic in age, are chiefly limestone, sandstone, phyllite, and metaporphyry, all of which have been subjected to greenschist-facies metamorphism. The rocks trend west-northwest and dip $15^{\circ}-45^{\circ} \mathrm{N}$. Detailed description of the geology, ore deposits, and mining history can be found in reports by Murdock (1958) and Barnes, Nackowski, and Bailey (1972).

The Konya area contains two groups of mines: the more productive Sizma mines lying south of the divide and the Ladik deposits 


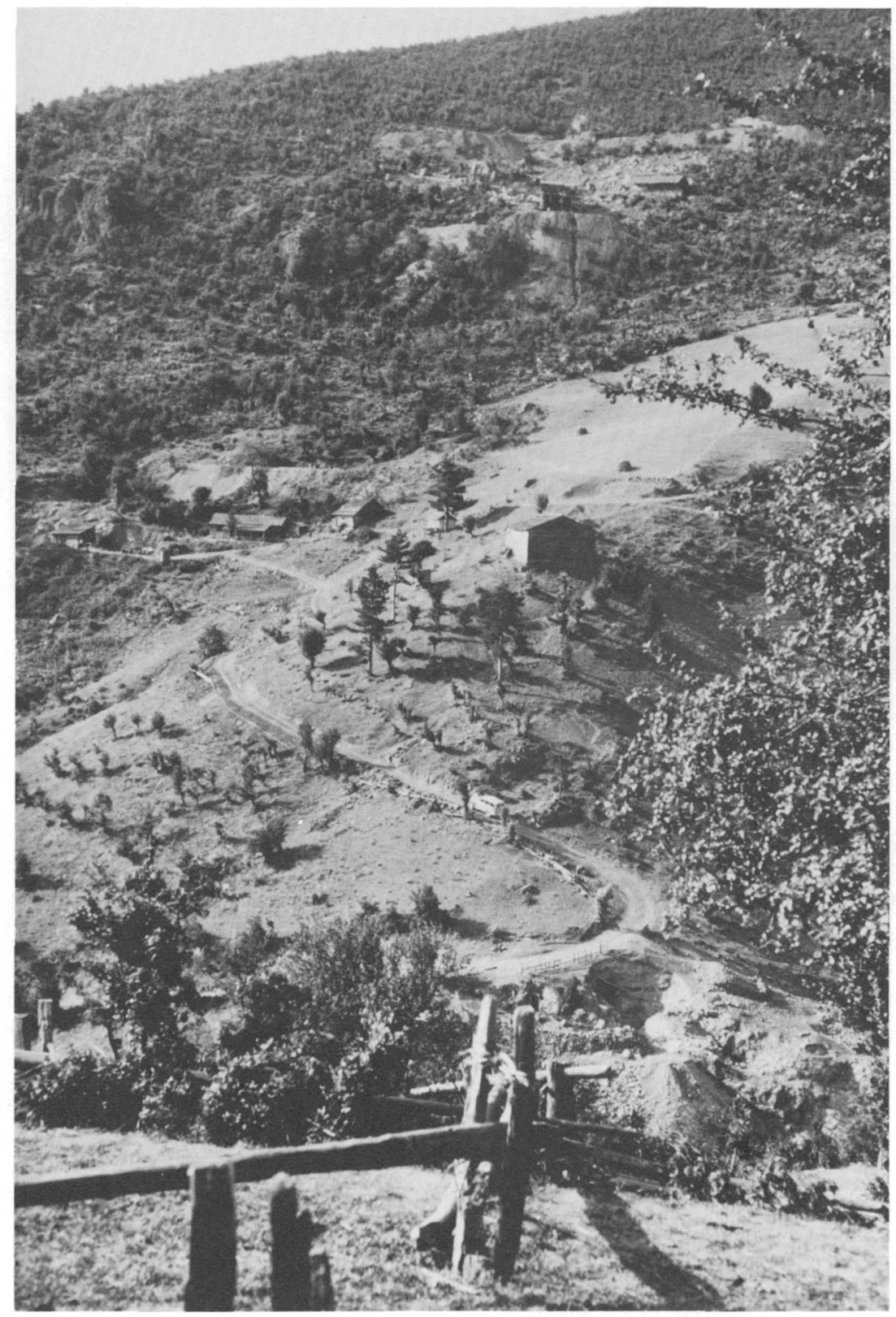

FiguRE 33. - S Seyhşaban mine viewed looking north. Low-level workings in lower right contained chiefly stibnite ore. Shaft furnaces above burnt ore dump cut by prominent gully near top of picture. 


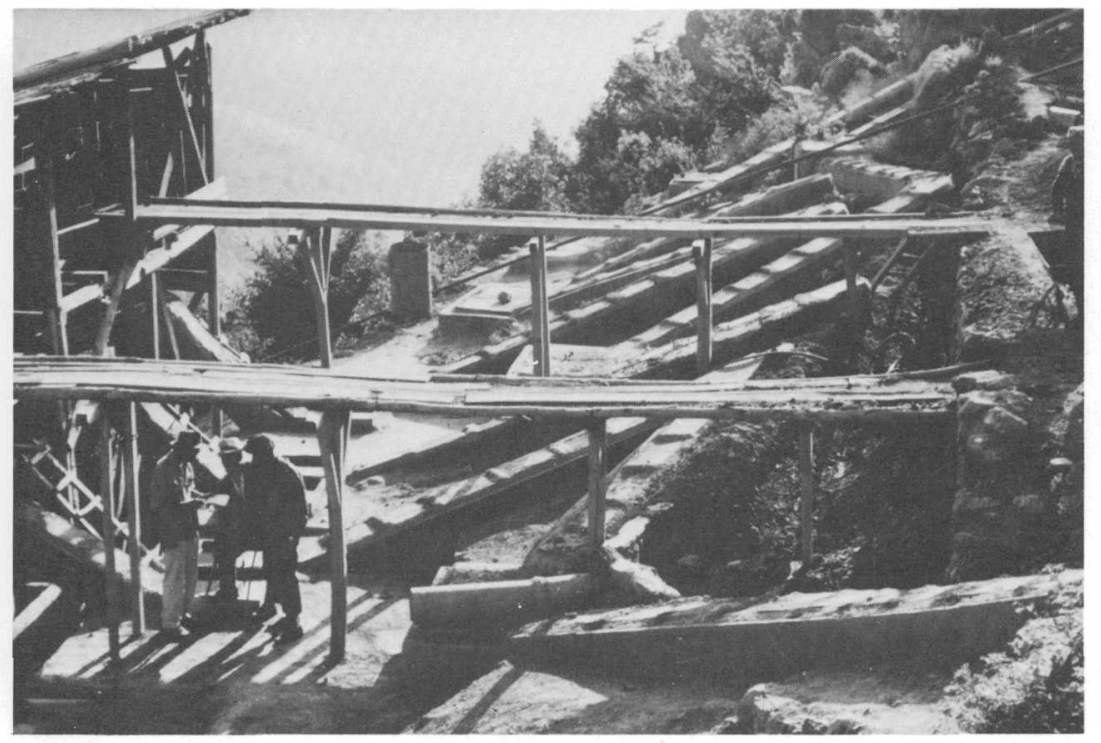

FIGURE 34.-Elaborate system of mercury-condensing troughs on hillside above shaft furnace in use at Şeyhşaban mine in 1966.

north of the divide about $5 \mathrm{~km}$ north of the Sizma group (see fig. 35). In 1974 both groups of deposits were being worked by Etibank, and their ores were being treated in a modern plant containing two 175tpd rotary furnaces. Production in 1974 was 5,680 flasks of mercury, bringing total production to about 45,000 flasks, the largest of any district in Turkey. In 1975 production was smaller because one of the large furnaces was moved to the Haliköy mine, where reserves were believed to be more extensive.

\section{SIZMA MINES (25)}

The Sizma mines consist of a cluster of three main mines-the Büyük, Çaliça, and Medrese-and numerous small workings and pits lying at an altitude of 1,650 to $1,850 \mathrm{~m}$ on the south slope of the divide. They are now perhaps most accessible by the ore haulage road extending from the north side but formerly were best reached from the village of Sizma, a few kilometers south of the mines. The total production of these mines has not been satisfactorily recorded but is estimated to be nearly 40,000 flasks, most of which came from the Büyük mine.

The rocks of the area consist of thick units of limestone interbedded with phyllite (fig. 35). They appear to make up a fairly orderly sequence dipping northward at moderate angles, but local isoclinal 


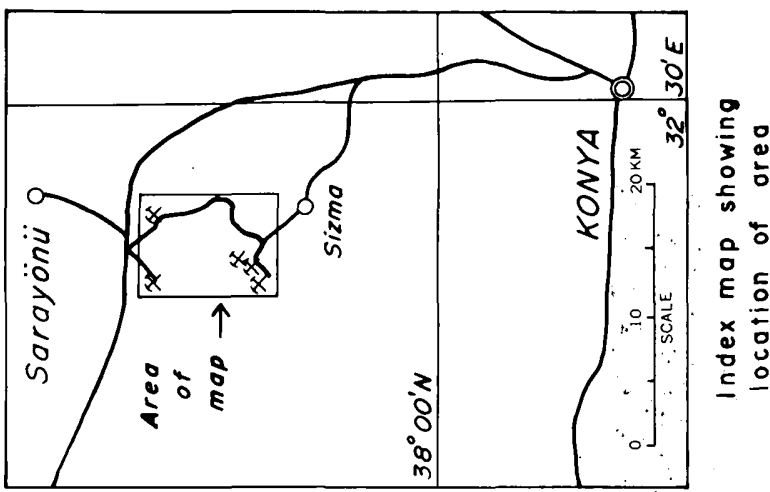

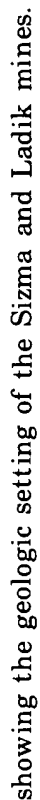
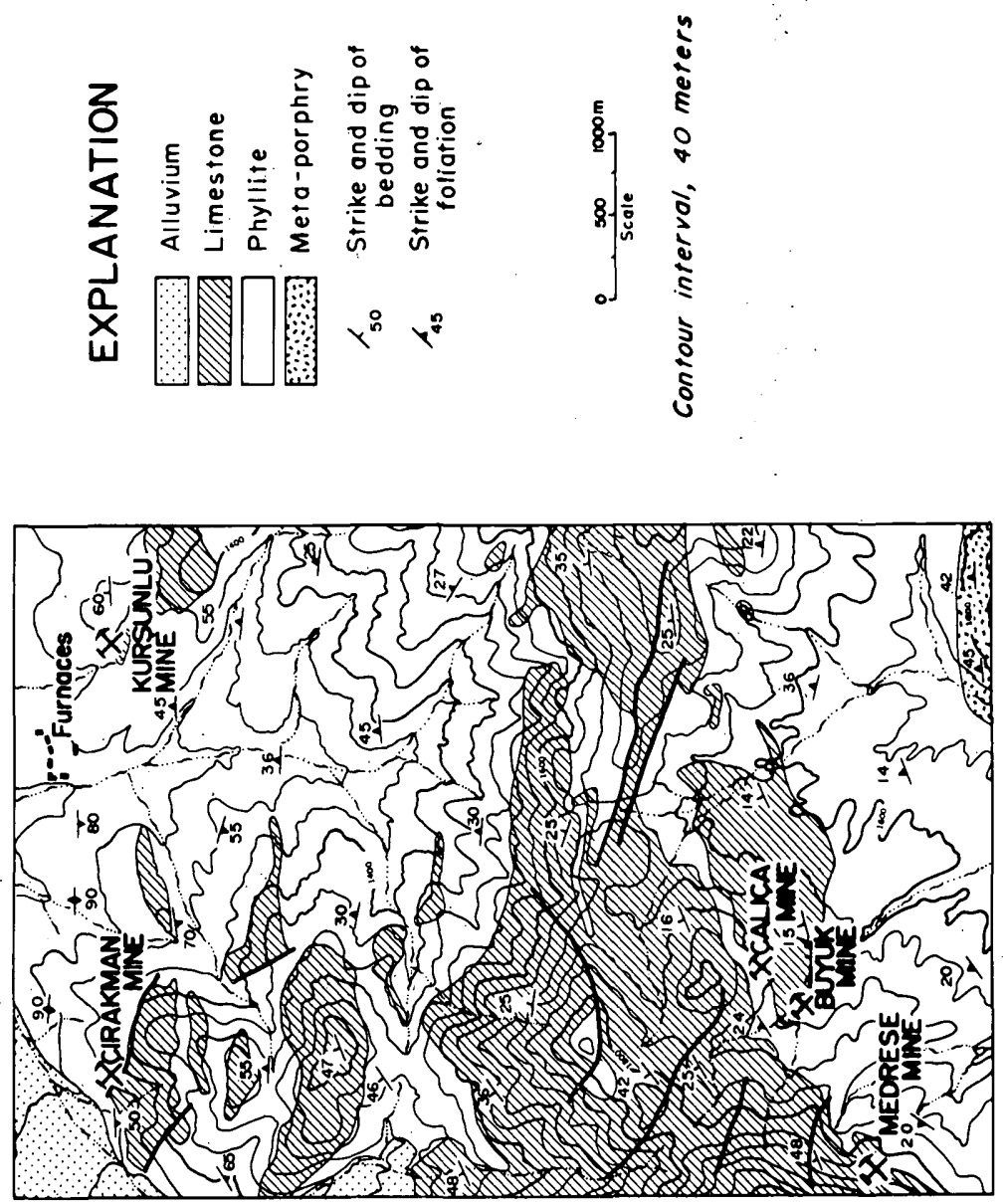

告 
folds suggest that the structure may be more complicated. Faults trending west to northwest offset the sedimentary contacts but do not seem to have a significant relation to the ore deposits.

Cinnabar is the most important mercury mineral, but metacinnabar and native mercury occur in small amounts. The former presence of mercury-bearing tetrahedrite reported by van der Kaaden (1966) is suggested by the occurrence of oxidized copper minerals, but in the ore they are very rare. Stibnite accompanies cinnabar in milky quartz in the largest deposit. Quartz occurs with cinnabar in fractures and replaces limestone in the ore bodies. Hydrothermal calcite occurs in veins with cinnabar only in broken limestone and may represent dissolved and reprecipitated limestone. Coarsely crystalline purple fluorite accompanies cinnabar, quartz, and calcite in veins in limestone, where it is a fairly common gangue mineral. Barite was reported by Höll (1966).

The Büyük mine, the oldest and largest mine in the Konya area, is centrally located among the Sizma deposits. Ore was mined here in ancient times in a near-surface cavernous stope that was obliterated in the development of recent opencuts (fig. 36). Ore at greater depth was mined through lower levels, some $43 \mathrm{~m}$ apart, and connected by a long incline having a $20^{\circ}$ slope. Altogether, there are

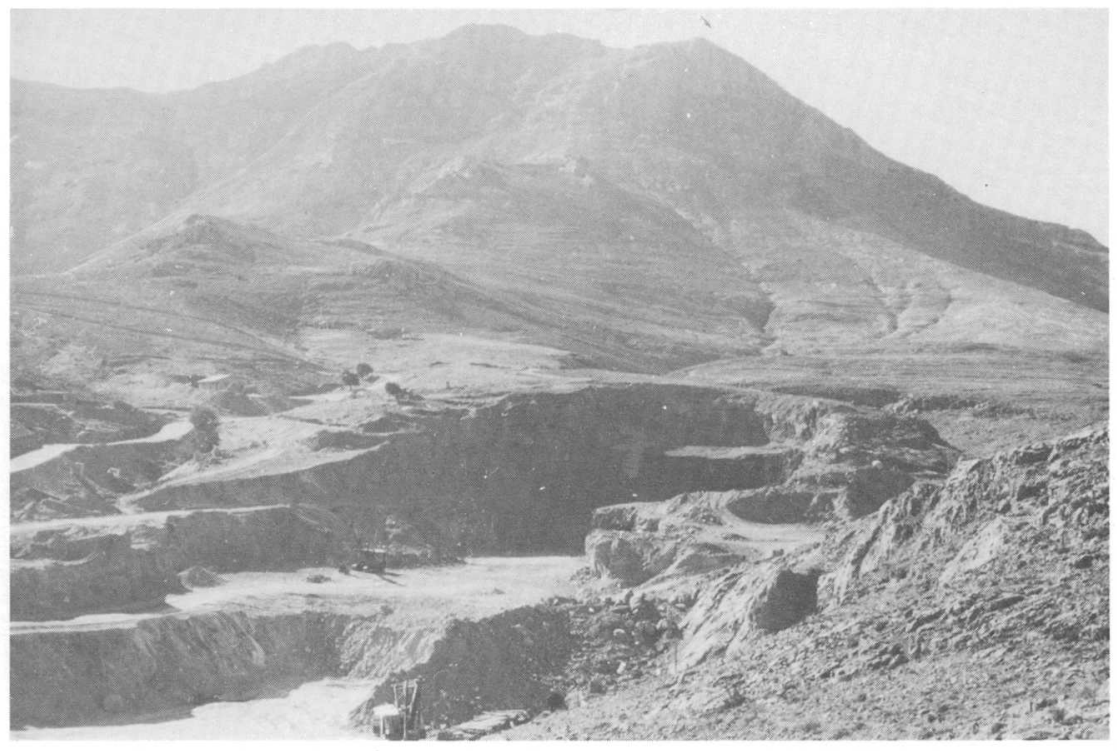

Figure 36.-Large opencut developed at the Büyük mine in the early 1970's. This deposit was the site of the cinnabar mining in prehistoric times, perhaps as early as 6,000 B.C. Rocky exposures in foreground and distant mountain are limestone; subdued topography in central area developed on phyllite. 
about 1,300 $\mathrm{m}$ of workings on the main levels and perhaps as much more in old shallow adits no longer accessible. Ore occurs where cinnabar is in patches and ramifying veinlets, forming minable masses to $2 \mathrm{~m}$ thick, 1 to $3 \mathrm{~m}$ wide, and 3 to $25 \mathrm{~m}$ long. The ore shoots are localized in limestone close beneath phyllite in minor anticlinal flexures in a westward-plunging anticlinal fold (see fig. 37). As mined in the early 1970's, the average grade was low, perhaps no more than 0.1 percent, but the ore can be readily hand sorted to a grade better than 0.5 percent, as was formerly done for shaft furnace and retort operation (fig. 38).

The Çaliça mine, $400 \mathrm{~m}$ northeast of the Büyük mine, contains ore localized in limestone beneath the same phyllite-limestone contact that controlled the position of the ore in the Büyük deposit. Here, however, the contact is nearly straight, generally dipping between $30^{\circ}$ and $60^{\circ}$ northwest. The small size of the Çaliça ore bodies perhaps results from the absence of favorable flexures such as those in the Büyük deposit.

At the Medrese mine, $900 \mathrm{~m}$ southwest of the Büyük mine, four adits explore limestone-phyllite contacts, one of which is the same as that which localized the ore of the Büyük mine. The ore is much like the Büyük ore in occurrence and mineralogy except that here fluorite is conspicuous. We have no data on the grade or quantity of ore stoped from the shoots on different contacts in the mine.

The modern discovery of mercury ore in the Sizma area was made in 1904, as well documented by Monachi (1908a, b) and Sharpless (1908). They tell how a goatherd driving his goats into a limestone cave by throwing rocks at them noticed that one rock was red and heavier than the others and so kept it. It eventually came into the hands of a woolbuyer in Istanbul who had been trained in the Royal School of Mines, and he recognized it as rich cinnabar ore. He subsequently arranged to go with the goatherd to examine the cave, where he found the walls laced with veinlets of cinnabar, for in reality the cave was an ancient mine excavation. After a little mining, he made a still more astonishing discovery: when breaking through the floor of the cave, he found a chamber containing 50 human skeletons encrusted with lime and accompanied by stone hammers, pottery lamps, and a few chipped artifacts. More examination showed the walls were grooved where cinnabar veinlets had been gouged out; obviously this chamber was once a mine working in which the ill-fated miners had been traped by an ancient cave-in. Sharpless thought this early mining was done by Phrygians about 1,000 B.C., but the absence of metal tools suggests that the miners belonged to an even earlier culture. 


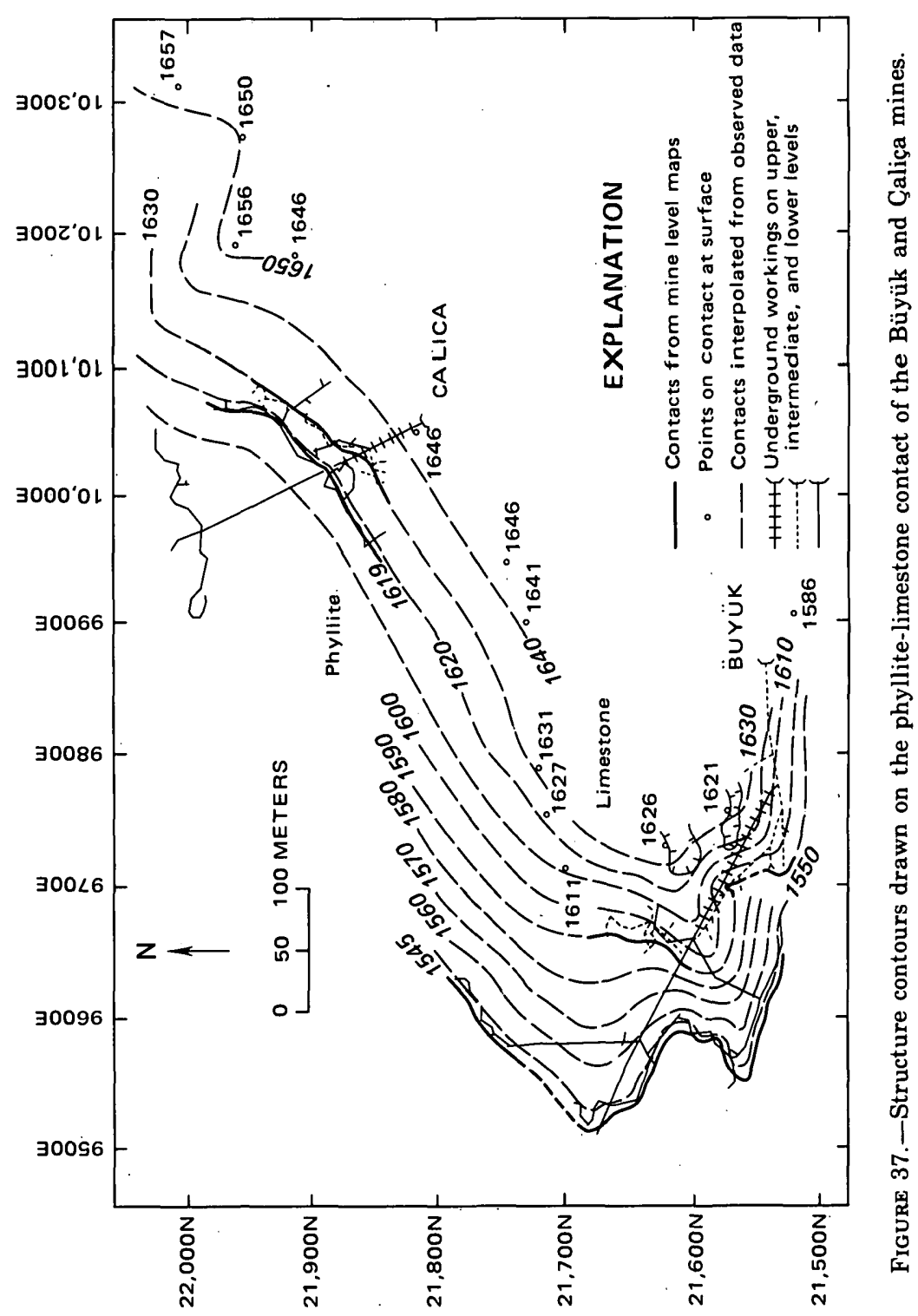




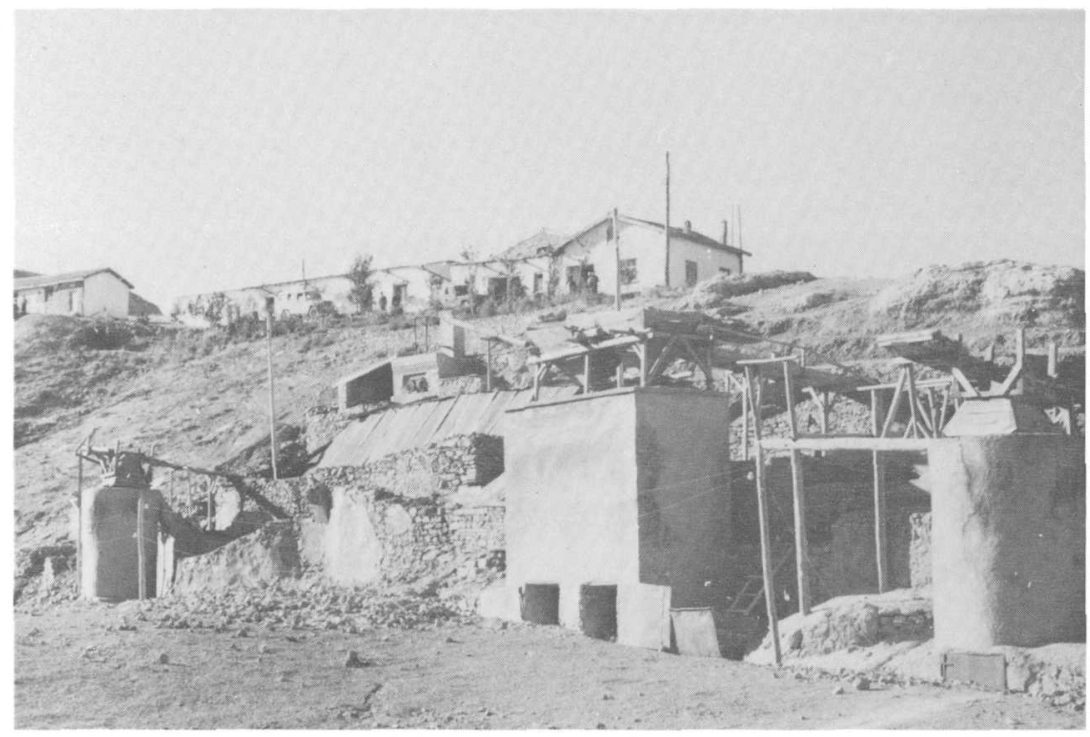

Figure 38.-Shaft furnaces being used at the Büyük mine in 1966; miners' houses in background. In 1972 ore was being hauled by Etibank to modern 175-tpd rotary furnace plant, and these structures were all destroyed.

Indirect evidence indicates the Sizma deposit was mined for cinnabar to be used as "paint" at a much earlier date. Some $65 \mathrm{~km}$ southeast of the mine, cinnabar-painted skulls were found by Mellaart $(1965$, p. 91; 1967) during the excavation of an early Neolithic village, Çatal Hüyük. The skulls were dated by radiocarbon methods at 6,280 years B.C., and, although there is no proof the cinnabar came from the Sizma mines, these are the nearest and most likely sources.

As documented in the following section describing the nearby Ladik mine, mercury mining was probably carried on in this area by Romans and Greeks.

Shortly after the rediscovery of the Büyük mine by the goatherd and woolbuyer, a British company obtained a mining concession, and incomplete records indicate that between 1906 and 1911, this company produced nearly 10,000 flasks by processing hand-sorted ore containing $1 \frac{1 / 2}{2}$ to 2 percent mercury through two shaft-type furnaces (Eng. and Mining Jour., 1908). From 1912-54 apparently only a little sporadic mining was done by local villagers (Ryan, 1957; Murdock, 1958). Between 1954 and 1964, various Turkish companies worked the Sizma deposits, producing 10,345 flasks of mercury, according to the U.S. Bureau of Mines (1964).

In 1964 Etibank acquired leases to all the major mines of the 
Konya area and began an aggressive exploration, development, and mining program. In 1969 they completed the installation of a modern 175-tpd rotary furnace plant (fig. 39). In 1970 a similar furnace was added; in 1975 it was moved to the Haliköy mine, also operated by Etibank.

Annual production since 1969 is as follows:

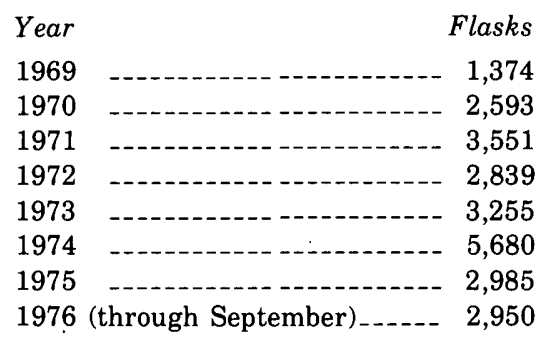

Extensive geologic and exploratory work was done in the area by MTA in 1973-74. At the end of their study, visible and probable ore was reported to be 491,000 tons with a grade of 0.15 to 0.35 percent mercury.

\section{LADIK MINES (26)}

The Ladik area, on the north slope of the main ridge but near the valley, is about $3 \mathrm{~km}$ south of Ladik, a small village near the Konya-Afyon highway. The area contains one major mine-the Çirakman mine, with a production of several thousand flasks of mercury-two small mines, and some other prospects.

The Çirakman mine ore bodies occur in and near a compound vertical fault zone trending nearly east and separating phyllite on the north from marble on the south (see figs. 40, 41). Cinnabar, accompanied by rare metacinnabar and native mercury, occurs as clots of grains and veinlets in broken silicified and dolomitized marble. Purple fluorite is fairly common and seems to be nearly contemporaneous with the cinnabar. A few specimens of realgar and orpiment have been found. The ore patches are generally less than $2 \mathrm{~m}$ wide and are quite discontinuous. Much of the ore is in marble along the fault, but good ore has also been found in the marble along fractures as far as $50 \mathrm{~m}$ from the fault. The ore has been mined through a vertical range of about $150 \mathrm{~m}$, and for $350 \mathrm{~m}$ along the fault zone in surface pits and four underground levels with an aggregate length of nearly $2,000 \mathrm{~m}$.

The Ladik area was mined for mercury in antiquity by the Romans and probably also by the Greeks. Near the Çirakman mine we found the bedrock hearth for a primitive retort (fig. 42), the oldest mercury extraction equipment yet discovered (Barnes and Bailey, 


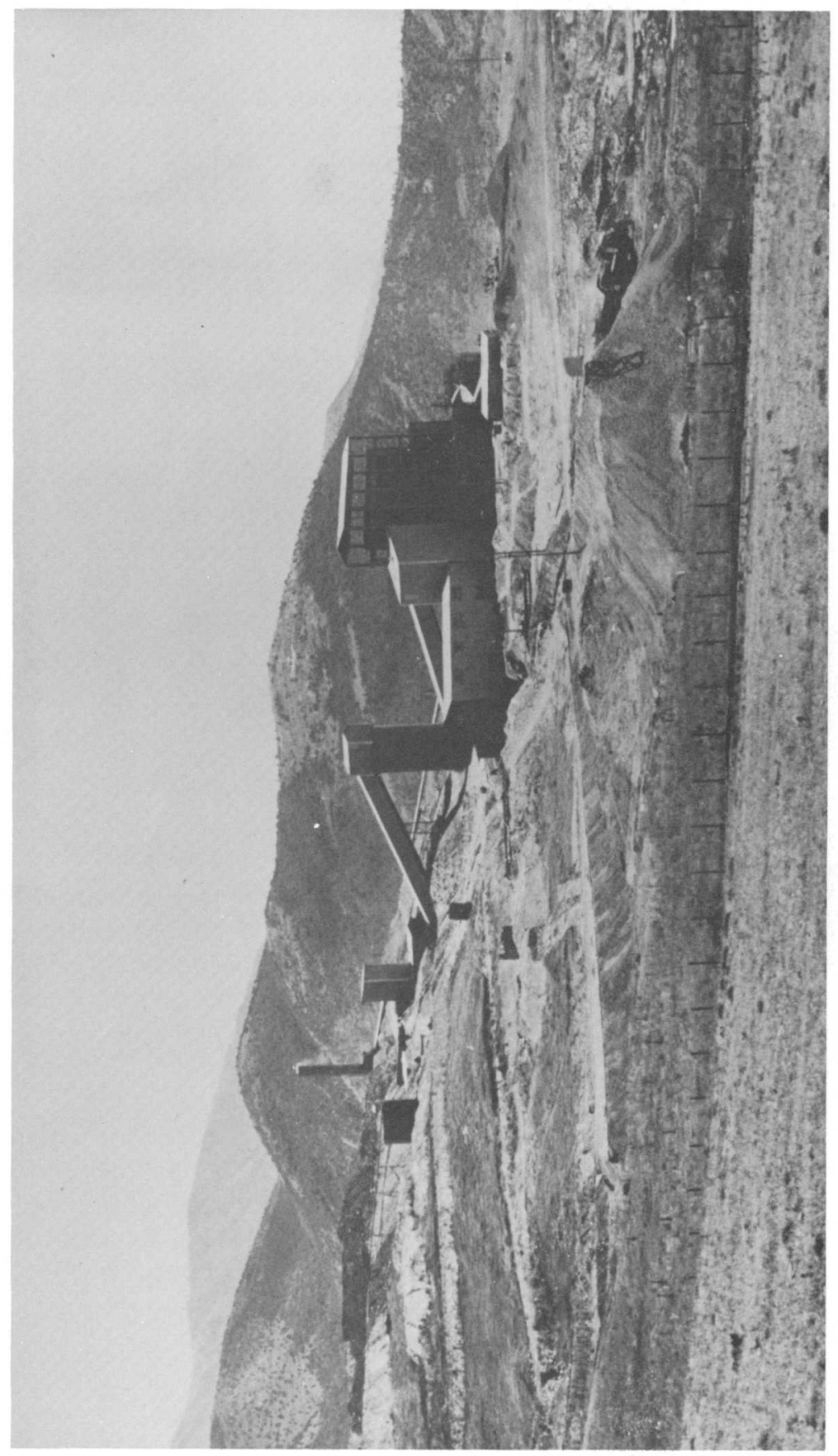

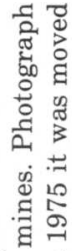

도

苂总

주

$\pi \frac{\pi}{3}$

हี ญ

in $\cdot \frac{N}{2}$

흐

․․ हี

范

ํㅝㅇ

(1)

屯ี

들

원

근

ซึ

ษ5

西

돓

.

도

先

교 웛

월

敢

풍

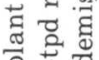

वर्व:

\&

ฮี

छี ฉ

돌

कृ

उ 80

।

कं I I

똥ำ

ड़ํㅇ

. 
1972; Barnes and others, 1972). A drawing of the "retort" site and a reconstruction (fig. 43) show how it may have looked when in use. To distill mercury, selected pieces of rich cinnabar ore were mixed with charcoal or wood and piled in the circular depression in the limestone slab, ignited, and covered with an inverted earthenware pot. Circulation of air was provided by a small inlet hole at the drainage channel at the base and an exit hole at the top connected with a long earthenware pipe extending up the hill. Mercury was volatilized by the fire and condensed on the walls of the pot or in the exhaust pipe. After firing, tapping of the chimney and pot caused the droplets to fall to the floor, where the ashes would float and the liquid metal could be coaxed through the drainage channel to collect in the bowllike depression at its end. We cannot accurately date the time of use of this retort, but the excavation is like other quarries nearby from which were taken stones now found in Ladik bearing Latin and Greek inscriptions.

The beginning of modern mining at the Çirakman deposit is not recorded. No doubt the deposit was operated on some scale during the 1906-11 period of major mining in the adjoining Sizma area (MTA, 1970, p. 11); there is some evidence that it was worked in the early 1950's, and in 1957-58 it yielded 177 flasks. In the early and middle 1960's it was being worked on a small-scale, producing mercury from sorted ore through the use of a small shaft furnace (fig. 44 ), but the quantity recovered is not known. After Etibank acquired the concession in 1964 and installed the large rotary furnace plant in 1969, the mine was aggressively developed and ore was hauled from it to the nearby plant. In 1972-73, MTA made a geologic study and tested for new ore bodies along the extension of the fault zone by drilling.

The productive Toprakle Bögurume Tepe deposit is $3 \mathrm{~km}$ south of Ladik and $1 \mathrm{~km}$ west of the Cirakman mine. Here cinnabar was found in a silicified zone in a marble lens in phyllite along a fault trending $\mathrm{N} .70^{\circ} \mathrm{W}$. up a hillside. Subsequent drilling in the floor of a wide canyon along the projection of the fault revealed an ore body in limestone beneath the alluvium. In 1973-74, after stripping $200,000 \mathrm{~m}^{3}$ of barren gravel to form an opencut about $150 \mathrm{~m} \times$ $50 \mathrm{~m} \times 30 \mathrm{~m}$ deep, the ore was mined by Etibank and hauled to their furnace for processing. The grade ranged between 0.1 and 1.0 percent mercury, and the total yield from the ore body was about 500 flasks.

The Kurşunlu mine is $2 \frac{1}{2} \mathrm{~km}$ east of the Çirakman mine and less than a kilometer east of Etibank's large mercury recovery plant. It was operated in the early 1960's and had a small production from the retorting of sorted ore that averaged about 1.0 percent mercury. 


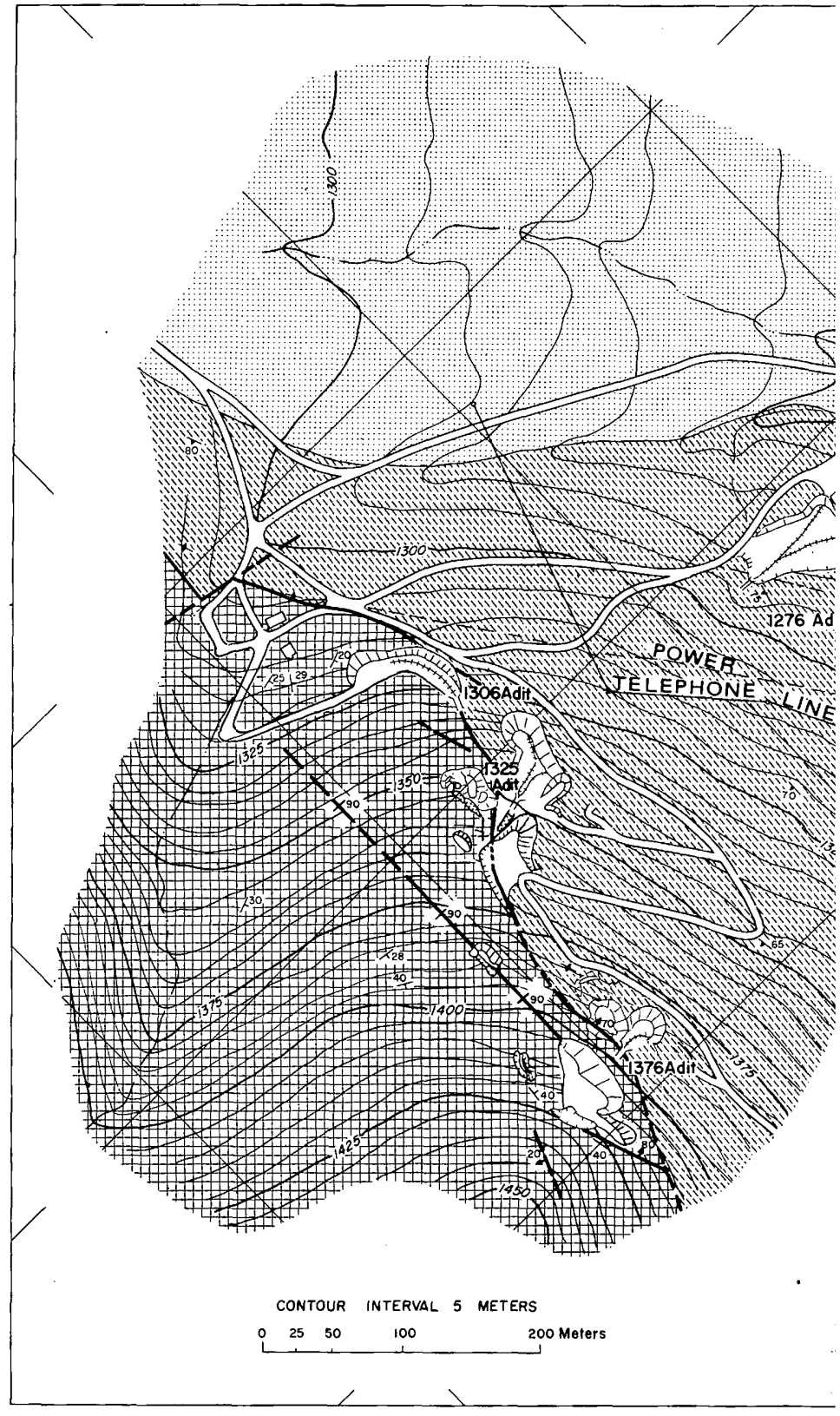

Figure 40.-Geologic map 


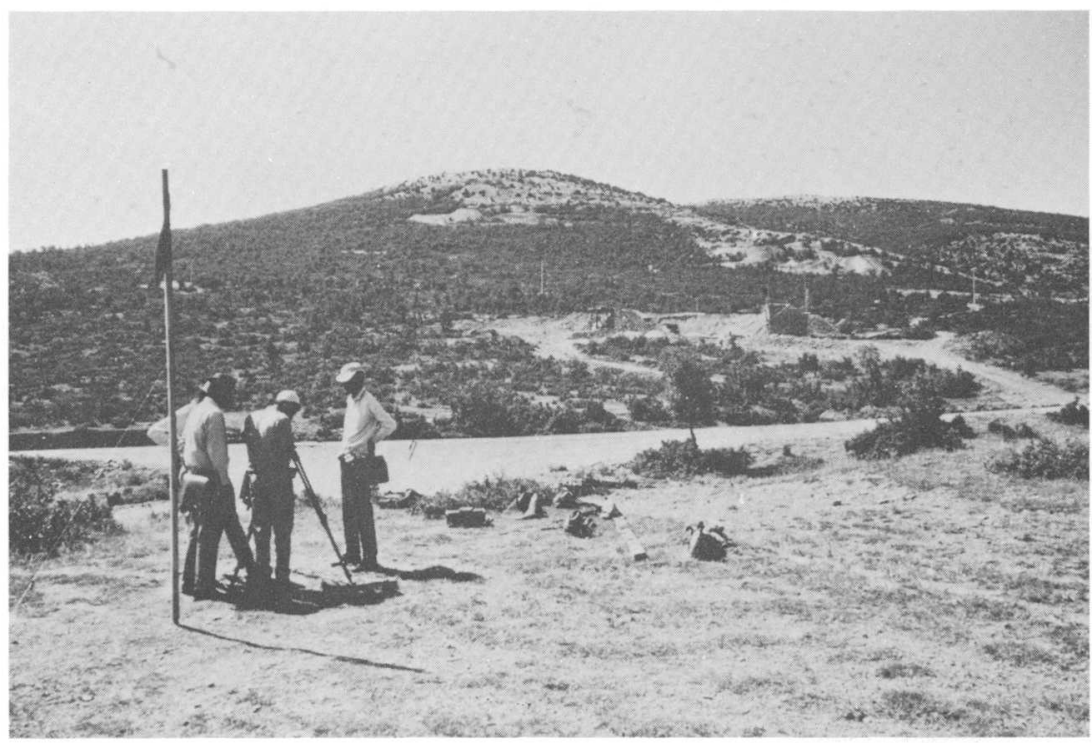

FIGURE 41.-View of Cirakman mine area south of Ladik. Ore zone and mine openings are along contact between marble-forming ridge extending to hill in center and phyllite covered by forest at left.

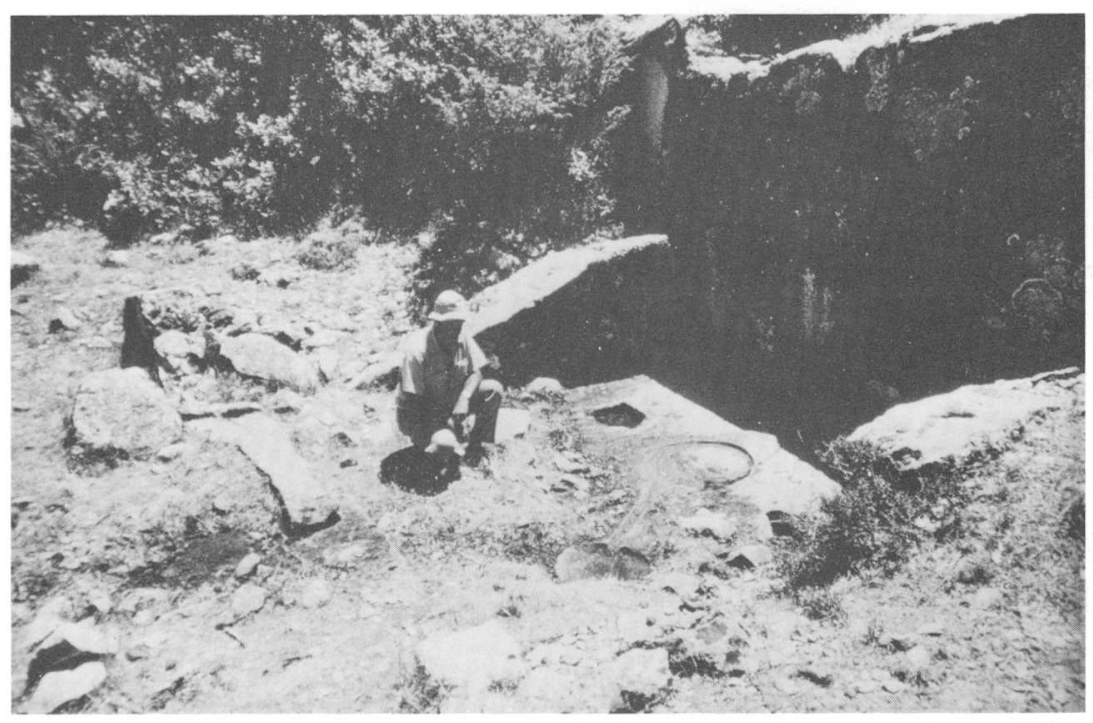

FIGURE 42.-Hearth of ancient mercury retort near Çirakman mine, believed to be oldest evidence of extraction of mercury from cinnabar by distillation yet discovered. 


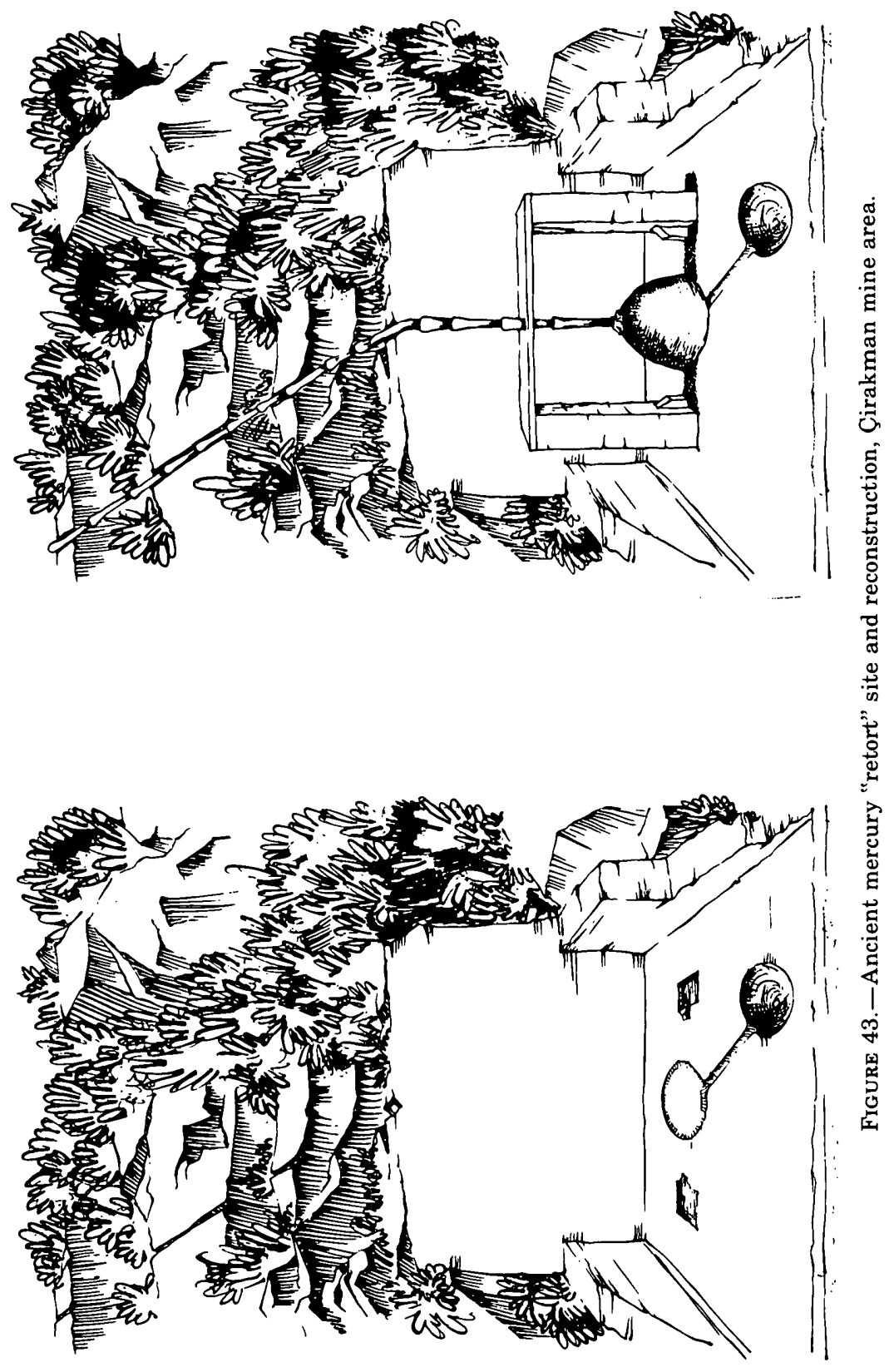




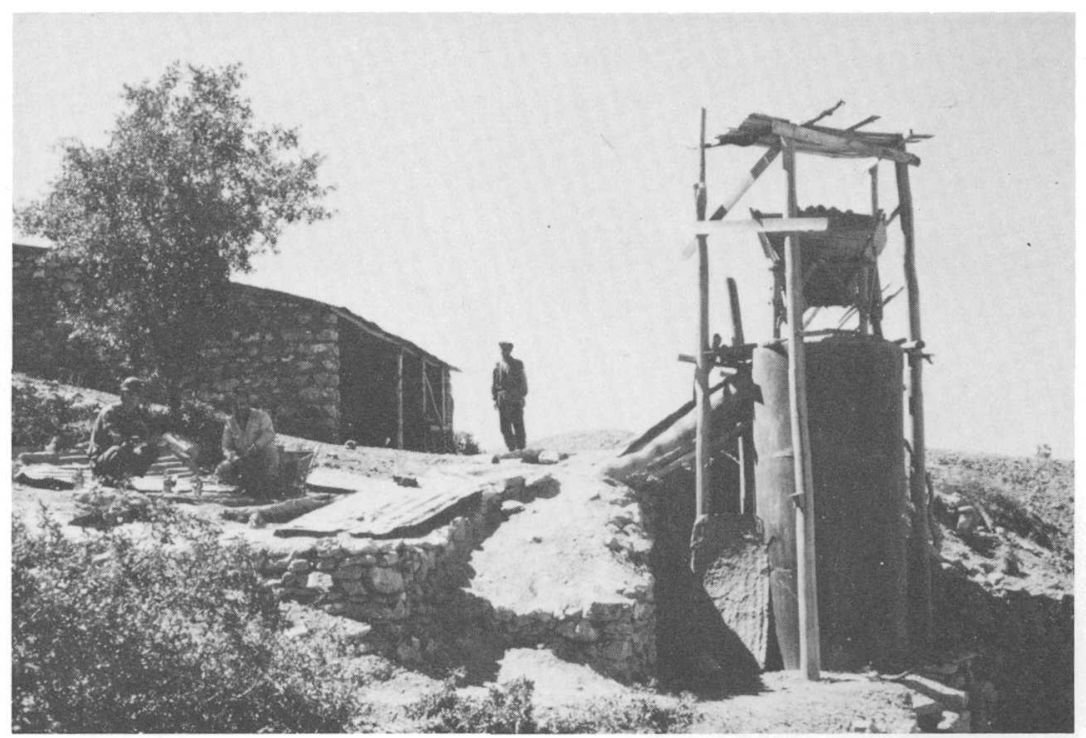

FIGURE 44.-Iron shaft furnace and ground-level condensing system in use at the Çirakman mine in 1966. After 1969 ore from here was hauled a short distance to the modern 175-tpd rotary furnace plant installed by Etibank south of Ladik.

The main ore occurred where cinnabar was in veinlets or patches in a steep fault zone about $1 \mathrm{~m}$ wide separating limestone from phyllite. Some cinnabar also is disseminated in small grains in zones 4 to $8 \mathrm{~m}$ wide and extending for a reported $180 \mathrm{~m}$. The total production is unknown but surely is very small.

The Muratbağ deposit, which has yielded little ore, is $4 \mathrm{~km}$ northwest of the Çirakman mine and adjacent to the Ladik plain. The ore occurrence is much like that at Cirakman, the cinnabar being in limestone along a fault separating it from phyllite, although the relative position of the two rocks is here reversed. Also occurring here is schwatzite, which on weathering yields malachite, azurite, secondary cinnabar, and antimony oxides. Only a little exploratory work is reported to have been done on this deposit.

\section{NIĞDE AREA}

The Niğde area, which includes unusual deposits containing cinnabar with stibnite, realgar, and scheelite, is in Niğde province 12 $\mathrm{km}$ southeast of the city of this name. Difficulties have arisen in processing the mixed ores, but retorting of sorted ore from at least two mercury deposits has resulted in the production of several hundred flasks of mercury.

The deposits lie at an altitude of 1,600 $\mathrm{m}$ and higher in a barren 
mountain region where exposures are very good. The dominant rocks are schist, gneiss, marble, quartzite, and amphibolite, metamorphosed in the almandine-amphibolite facies and generally regarded as Paleozoic in age. They are cut by dikes of granodiorite, micropegmatite, and aplite, some of which show a tectonic fabric. Veins of quartz, locally containing black tourmaline, occur throughout the schist, and quartz lenticles and segregations are common. Within less than $10 \mathrm{~km}$ of the ore deposits are stocklike masses of granite and gabbro. The metamorphic rocks are broadly folded into an anticlinal flexure plunging gently to the southwest, and the ore bodies are localized near the crest of the fold, as shown in figure 45 .

It has been postulated that the arch structure may be the result of the intrusion of a still-concealed granite mass that has given rise to the dikes, veins, and possibly even the tungsten mineralization. As late Cenozoic rhyolite flows and tuffs overlie the metamorphic rocks to the north, west, and south, the antimony, arsenic, and mercury mineralization may be related to this young igneous activity.

\section{GÜMÜŞLER MINE (27)}

The Gümüşler mine, the main deposit in the Niğde area, is reached from Niğde by driving north $10.5 \mathrm{~km}$ to the village of Gümüşler, then following a dirt road southeast for $6 \mathrm{~km}$. Because of the difficulty of separating the cinnabar, stibnite, and scheelite in the ore, this deposit has produced only a little mercury, some antimony ore, and a few hundred tons of scheelite ore.

The unusual $\mathrm{Hg}-\mathrm{Sb}-\mathrm{W}$ mineralization at the Gümüşler mine (fig. 45) was the subject of a preliminary article by Wendel (1967) and a detailed thesis study by Dennis (1970), from whose work most of the following data are taken. Cinnabar, stibnite, some realgar, and scheelite all occur together with some quartz in a compound vein 25 to $300 \mathrm{~cm}$ thick along a fault zone that is mostly in marble. The ore zone strikes east-southeast and dips $40^{\circ}-45^{\circ} \mathrm{N}$. (fig. 45). The mineralization extends about $900 \mathrm{~m}$ along the strike and has been explored by adits and opencuts over a vertical range of $100 \mathrm{~m}$. Stibnite is the most common ore mineral, scheelite is patchy and nearly absent from the central part of the lode, and cinnabar is erratically distributed as crusts along fractures and in patches and lenses. Realgar is more common in schist where cinnabar is rare. Quartz is the main gangue mineral and has replaced marble over a width of $30 \mathrm{~cm}$ from the main fractures. Near the surface the stibnite ores are oxidized to cervantite and senarmontite, and some of the cinnabar is the orange-red powdery variety of possible supergene origin. Scheelite mineralization results from selective replacement of marble along the shear zone walls and locally occurs as nearly pure 


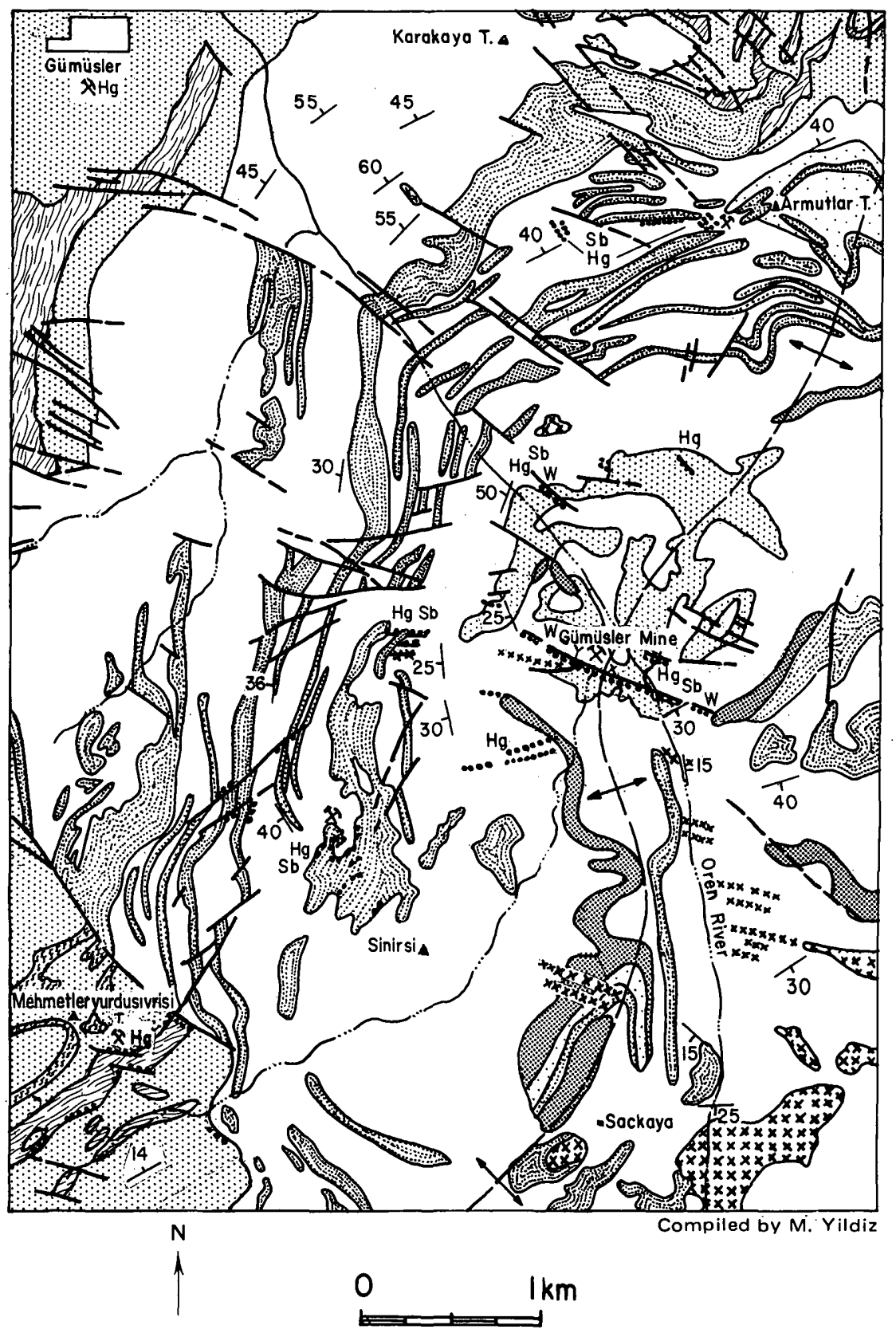

Figure 45.-Niğde area showing 
lenses more than a meter wide and several meters long. Stibnite and quartz are more common within the fault zone as vein material. Yildiz found the paragenesis to be calcite-scheelite(brecciation)quartz-barite-arsenopyrite-pyrite-chalcedony-stibnite-cinnabar. The scheelite is commonly fractured, but the chalcedony, which locally replaces it, along with stibnite and cinnabar, is unfractured. The mercury and arsenic mineralization is thought by Dennis to be Alpine, the antimony mineralization early Alpine, and the tungsten Hercynian or late Caledonian.

The deposit was worked in antiquity, possibly by the Romans judging by ruins in the vicinity, and perhaps for its cinnabar content. In 1963 the rich stibnite part of the ore was discovered and mined by a private company, but when an attempt was made to sell

\section{EXPLANATION}

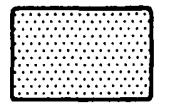

White marble

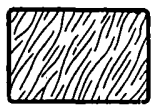

Amphibolite and biotite schist

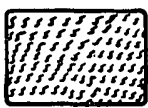

Pyroxene-bearing amphibolite

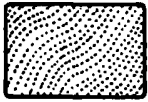

Gray and white marble

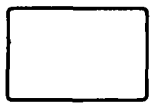

Biotite schist

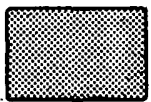

Amphibolite

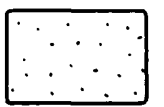

Quartzite

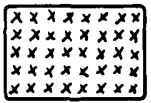

Granodiorite and aplite

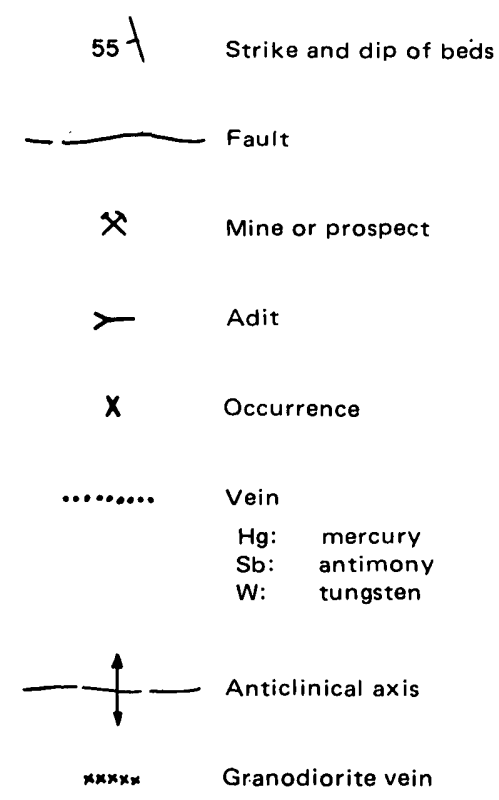

location of mineral deposits. 
a hand-cobbed antimony concentrate at Mersin, cinnabar was discovered in it, rendering its sale impossible. Renewed exploration, this time for cinnabar, found some rich pockets and some mined-out ancient workings. A consultant at Middle East Technical University, hired to solve the problem of separation of the mercury from the antimony, which clogs condensing pipes in mercury retorts, discovered that the ore contained grains of scheelite. Later search at the mine with an ultraviolet light, which causes scheelite to fluoresce, revealed considerable scheelite throughout much of the ore zone. To search for and mine these mixed ores, eight adits have been run into the vein, and by 1973 drifts along it totaled about $1,000 \mathrm{~m}$.

By late 1965 three pairs of inclined retorts were being used to process pieces of sorted mercury ore that had a grade of 0.5 to 1.0 percent (figs. 46-48). In addition, an attempt was being made to make stibnite and scheelite concentrates usable by hand sorting and by crushing, tabling, and flotation. Although there was some difficulty in obtaining clean separations, some concentrates of stibnite and of scheelite were marketed. Later mercury ores from the

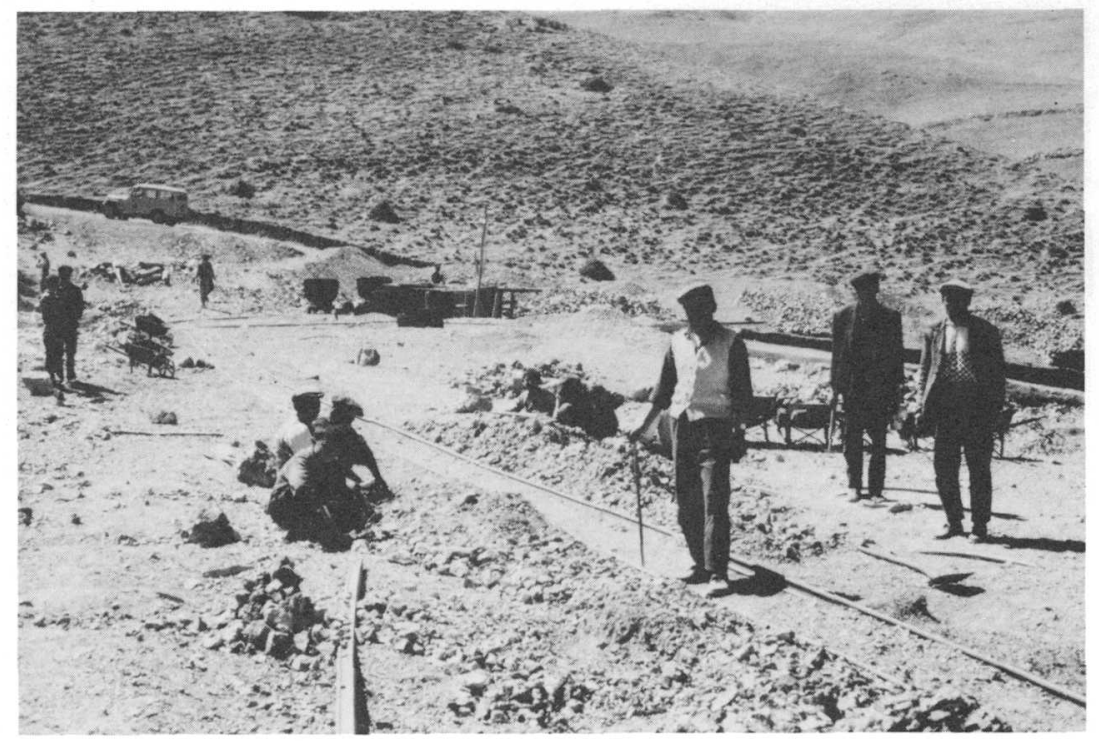

FIGURE 46.-Sorting ore from Gümüşler mine into cinnabar-rich, stibnite-rich, and scheelite-rich piles. 
nearby Mehmetleryurdu Sivrisi deposit, which contained very little contaminating stibnite, were processed through the Gümüşler retorts.

\section{MEHMETLERYURDU SIVRISI TEPE MINE (28)}

The Mehmetleryurdu Sivrisi Tepe cinnabar deposit is $3 \mathrm{~km}$ southwest of the Gümüşler mine on the southeast slope of Mehmetleryurdu Sivrisi, a steep mountain peak more than 2,100 m high (see fig. 45). Cinnabar occurs in small irregular veins in brecciated silicified limestone in several zones striking east and dipping steeply to the south. The ore contains only a little antimony, mostly present as the oxide cervantite. Minor amounts of pyrite occur with the cinnabar; no scheelite has been found. The deposit has been mined through three adits and a few hundred meters of underground workings. The ore has all been hauled to the Gümüşler mine for processing. Grade of the sorted ore ranges from 0.2 to 1.0 percent mercury. The exact production is unknown, but by 1973 probably was less than 100 flasks.

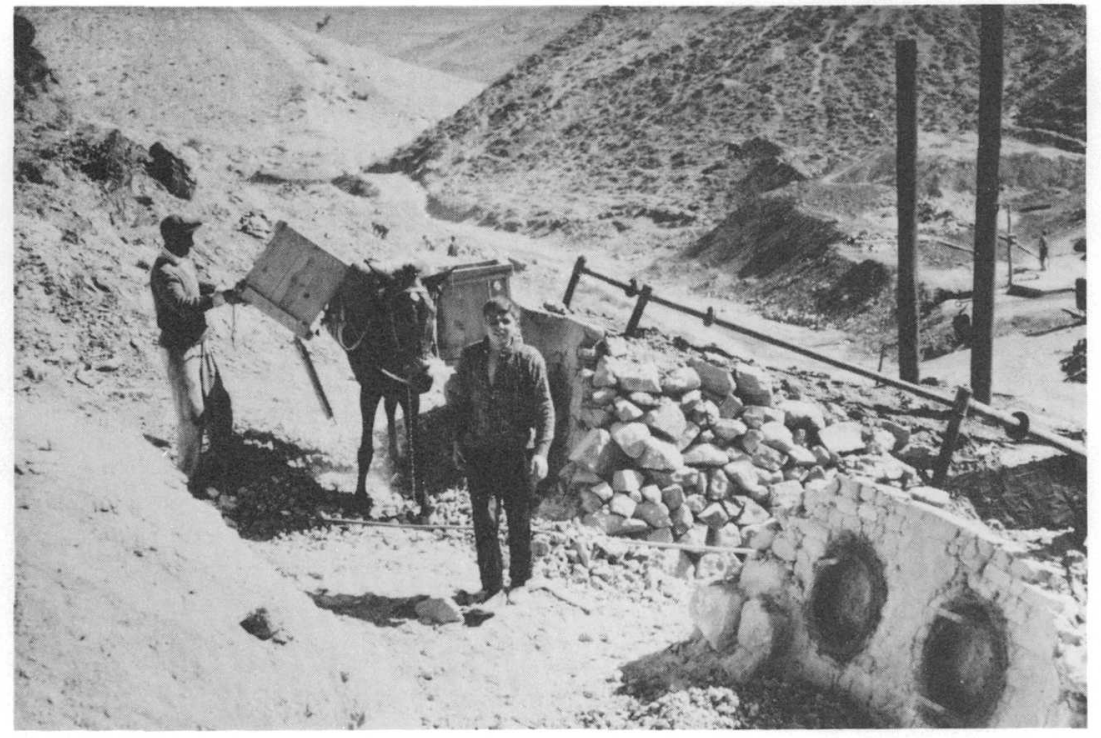

Figure 47.-Emptying boxes of hand-sorted ore to be charged into Rossi-type retorts at the Gümüşler mine. 


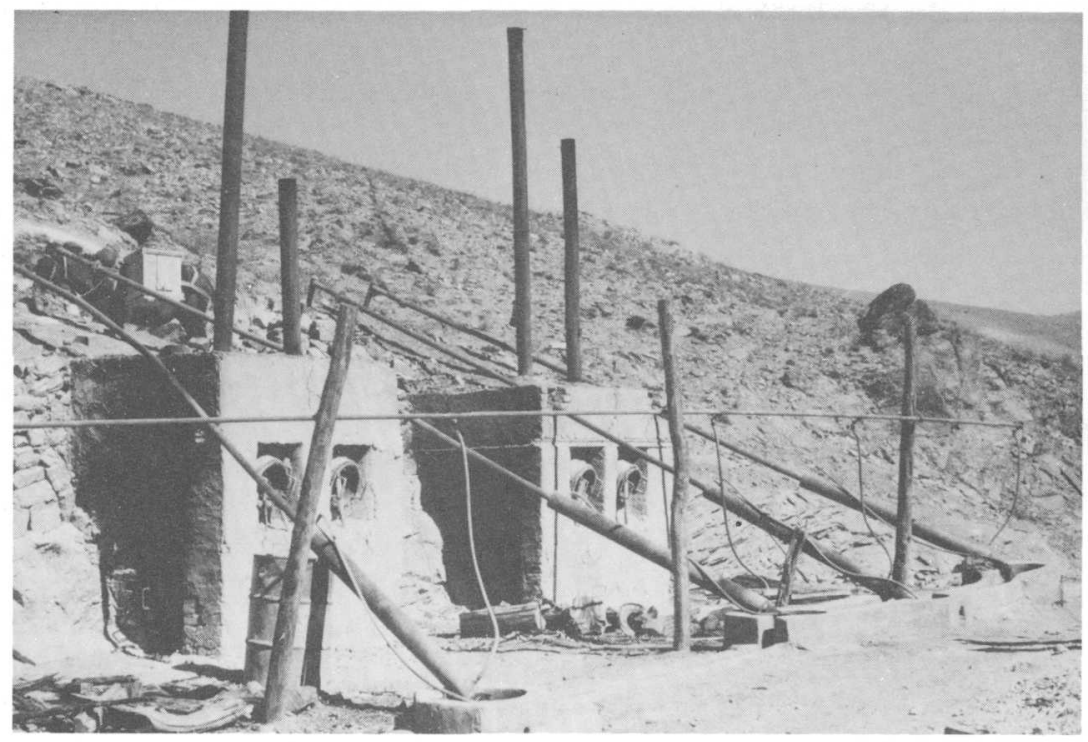

FIGURE 48.-Inclined-pipe Rossi-type retorts being used to recover mercury from hand-sorted ore at Gümüşler mine in 1966.

\section{OTHER DEPOSITS}

Except for a little mercury ore mined from a deposit $1 \mathrm{~km}$ south of the village of Gümüşler, none of the other deposits shown on the map of the Niğde area (fig. 45) has had production in recent time. About 50 years ago some antimony ore is reported to have been taken from the deposit near Armutlar Tepe.

One small occurrence of cinnabar ore is outside the map area about $25 \mathrm{~km}$ east of the Gümüşler mine, but no mercury has been recovered here. In 1972 three small mercury deposits were found about $50 \mathrm{~km}$ northwest of Niğde and east of Aksaray.

\section{REFERENCES CITED}

Bailey, E. H., 1959, Mercury resources of the world, in Mercury, a materials survey: U.S. Bur. Mines Inf. Circ. 7941, p. 12-17.

Bailey, E. H., Barnes, J. W., and Kupfer, D. H., 1967, Geology and ore deposits of the Küre district, Kastamonu province, Turkey: Ankara, Turkey, Central Treaty Organization (CENTO) Summer Training Program in Geological Mapping Techniques, Pt. 2, p. 17-73.

Bailey, E. H., Clark, Allan, and Smith, R. M., 1973, Mercury, in Brobst, D. A., and Pratt, W. P., eds., United States mineral resources: U.S. Geol. Survey Prof. Paper 820 , p. $401-414$.

Barnes, J. W., and Bailey, E. H., 1972, Turkey's major mercury mine today and how it was mined 8,000 years ago: World Mining, v. 25, no. 4, p. 49-55. 
Barnes, J. W., Nackowski, M. P., and Bailey, E. H., 1972, Geology and ore deposits of the Sizma-Ladik mercury district, Turkey: Ankara, Turkey, Central Treaty Organization (CENTO), $35 \mathrm{p}$.

Bekisoğlu, K. A., 1968, Türkiye civa yataklari ve bunlarin ekonomik önemi [Turkish mercury deposits and their economic importance]: Ankara, Turkey (published privately), $30 \mathrm{p}$.

Central Treaty Organization (CENTO), 1964, Haliköy mercury deposits, Izmir province; Description of Haliköy mercury mine, Ödemis County, Izmir province: CENTO Symposium on Mining Geology and the Base Metals, Ankara, Turkey, 1964, Rept., p. 47-49. 65-67.

Dennis, R. A., 1970, The mineralization at the Hg-Sb-W mine near Niğde, south central Turkey: Swansea Univ. Coll., Dept. Geology, Swansea, Wales, M.S. thesis.

Dickson, F. W., 1964, Solubility of cinnabar in $\mathrm{Na}_{2} \mathrm{~S}$ solutions at $50^{\circ}-250^{\circ} \mathrm{C}$ and 1-1800 bars, with geologic applications: Econ. Geology, v. 59, p. 625-635.

Dickson, F. W., and Tunell, George, 1958, Equilibria of red HgS (cinnabar) and black $\mathrm{HgS}$ (metacinnabar) and their saturated solutions in the systems $\mathrm{HgS}-\mathrm{Na}_{2} \mathrm{~S}-\mathrm{H}_{2} \mathrm{O}$ and $\mathrm{HgS}-\mathrm{Na}_{2} \mathrm{~S}-\mathrm{Na}_{2} \mathrm{O}-\mathrm{H}_{2} \mathrm{O}$ from $25^{\circ} \mathrm{C}$ to $75^{\circ} \mathrm{C}$ at 1 atmosphere pressure: $\mathrm{Am}$. Jour. Sci., v. 256, p. 654-679.

1959, The stability relations of cinnabar and metacinnabar: Am. Mineralogist, v. 44 , p. $471-487$.

Engineering and Mining Journal, 1908, Turkish quicksilver mining: Eng. and Mining Jour., v. 86, July 11 , p. 85.

Evans, Graham, 1971, The recent sedimentation of Turkey and the adjacent Mediterranean and Black Seas, a review, in Campbell, A. S., ed., Geology and history of Turkey: Tripoli, Petroleum Explor. Soc. Libya, p. 385-406.

Gilluly, James, Reed, J. C., Jr., and Cady, W. M., 1970, Sedimentary volumes and their significance: Geol. Soc. America Bull., v. 81, p. 353-376.

Höll, Rudolf, 1966, Genese und Altersstellung von Vorkommen der Sb-W-Hg Formation in der Türkei und auf Chios/Griechenland: Bayerische Akad. Wiss., Matt.Naturw. Kl., no. 127, 118 p.

Kalafatcioglu, A., 1961, A geological study in the Karaburun Peninsula: Maden Tetkik ve Arama Enst. (MTA) Bull. 56, p. 40-49. [Ankara, Turkey.]

Kamen-Kaye, Maurice, 1971, A review of depositional history and structure in Turkey, in Campbell, A. S., ed., Geology and history of Turkey: Tripoli, Petroleum Explor. Soc. Libya, p. 111-137.

Ketin, I., 1966, Tectonic units of Turkey: Maden Tetkik ve Arama Enst. (MTA) Bull., Foreign Ed., v. 66, p. 1-22. [Ankara, Turkey.]

Krauskopf, K. K., 1951, Physical chemistry of quicksilver transportation in vein fluids: Econ. Geology, v. 46, no. 5, p. 498-523.

Ktenas, K. A., 1925, Contribution a l'étude geólogique de la presqu'ile d'Erythrée (Asie Mineure): Athens, Ann. Sci. de la faulte des Sciences, A-1, p. 1-57.

Marico, T., 1970, Some antimony deposits and occurrences of cinnabar in the Ivrindi district, Balikesir: Maden Tetkik ve Arama Enst. (MTA) Rept. M86. [Ankara, Turkey.]

Mellaart, James, 1965, Earliest civilizations of the Near East: London, Thames and Hudson, Ltd., $143 \mathrm{p}$. 1967, Çatal Hüyük, a Neolithic town in Anatolia: New York, McGraw-Hill Book Co., 232 p.

Monachi, F. P., 1908a, Cinnabar mines in Turkey: London Mining Jour., v. 83, p. 517. 1908b, Rassegna Mineraria [abs.]: Eng. and Mining Jour., April 11, p. 138.

Maden Tetkik ve Arama Enstitüsü (MTA), 1969, Turkiye Cive Envanteri (Turkish mercury resources): Maden Tetkik ve Arama Enst. (MTA) Yayinlarinden 143, 52 p. [Ankara, Turkey.] 
1970, Arsenic, mercury, antimony, and gold deposits of Turkey: Maden Tetkik ve Arama Enst. (MTA) Bull. 129, p. 1-26. [Ankara, Turkey.] (A revision by M. Yildiz of an earlier report by G. van der Kaaden).

Murdock, T. G., 1958, Mercury deposits of the Konya region: U.S. Bur. Mines Mineral Trade Notes, v. 47 , no. 3 , p. 42-57.

Ryan, C. W., 1957, A guide to the known minerals of Turkey, rev. ed.: Mineral Research Explor. Inst. Turkey and Office Internat. Econ. Coop., in cooperation with U.S. Operation Mission to Turkey, 136 p. (See also MTA rept. 2603, 1936.)

Sharpless, F. F., 1908, Mercury mines at Koniah, Asia Minor: Eng. and Mining Jour., v. 86 , no. 13 , p. $601-603$.

Tunell, George, 1970, Mercury, in Handbook of geochemistry, Volume II/2: Berlin, Springer-Verlag, p. 80-B-1 to 80-M-1.

U.S. Bureau of Mines, 1962, Mercury (Şayhşaban deposit): U.S. Bur. Mines Mineral Trade Notes, v. 55, no. 5, p. 30-32.

1964, Mercury [Konya]: U.S. Bur. Mines Mineral Trade Notes, v. 59, no. 3, p. $42-47$.

van der Kaaden, G., 1966, The significance and distribution of glaucophane rocks in Turkey: Maden Tetkik ve Arama Enst. (MTA) Bull. 52, p. 1-14. [Ankara, Turkey.]

1971, Basement rocks of Turkey, in Campbell, A. S., ed., Geology and history of Turkey: Tripoli, Petroleum Explor. Soc. Libya, p. 191-209.

Weiss, K. E., 1901, Kurze Mittheilungen über Lagerstatten im westlichen Anatolien: Zeitschr. für praktische Geologie Jahrb. 9, p. 255-257.

Wendel, C. A., 1967, A unique mineral assemblage in Turkey: Econ. Geology, v. 62, no. 2, p. 276-278.

Yildiz, Mehmet, 1967, Mercury: Maden Tetkik ve Arama Enst. (MTA) Bull. S68 [In Turkish]. [Ankara, Turkey.]

1969, Report on Karaburun mercury mine: Maden Tetkik ve Arama Enst. (MTA) Rept. 4119. [Ankara, Turkey.] 